\title{
Sixty-one macrofungi species new to Hungary in Őrség National Park
}

\section{Siller $\mathbf{I}^{1}$, Kutszegi $\mathbf{G}^{2^{*}}$, Takács $\mathrm{K}^{3}$, Varga $\mathrm{T}^{4}$, Merényi $\mathrm{Zs}^{4}$, Turcsányi $\mathrm{G}^{3}$, Ódor $\mathbf{P}^{2}$ and Dima $\mathbf{B}^{3}$}

${ }^{1}$ Department of Botany, Institute of Biology, Faculty of Veterinary Science, Szent István University, P.O. Box 2, H1400 Budapest, Hungary

${ }^{2}$ MTA Centre for Ecological Research, Institute of Ecology and Botany, Alkotmány út 2-4, H-2163 Vácrátót, Hungary

${ }^{3}$ Department of Nature Conservation and Landscape Ecology, Szent István University, Práter Károly utca 1, H-2100 Gödöllö, Hungary

${ }^{4}$ Department of Plant Physiology and Molecular Plant Biology, Eötvös Loránd University, Pázmány Péter sétány 1/C, H-1117 Budapest, Hungary

Siller I, Kutszegi G, Takács K, Varga T, Merényi Zs, Turcsányi G, Ódor P, Dima B 2013 - Sixtyone macrofungi species new to Hungary in Örség National Park. Mycosphere 4(5), 871-924, Doi $10.5943 /$ mycosphere $/ 4 / 5 / 3$

\begin{abstract}
In this paper, an annotated checklist of macrofungi from Örség National Park, West Hungary, is provided. A total of 726 macrofungi taxa representing 214 genera, 84 classes and 2 phyla (Ascoand Basidiomycota) were revealed. Sixty-one macrofungi species were new to the mycobiota of Hungary. Sporocarps were collected three times (in May, August and September-October) between 2009 and 2010 in $35(40 \mathrm{~m} \times 40 \mathrm{~m})$ forest stands with different tree species compositions. Preferred tree species compositions and substrata of registered macrofungi are also listed.
\end{abstract}

Key words - Ascomycota - Basidiomycota - checklist - fungal diversity - mycobiota - Örs-erdő Project

\section{Introduction}

In this paper, an annotated checklist of macrofungi collected in the frame of a multitaxonomic study, Örs-erdő Project, is provided. Örs-erdő Project (carried out in Örség National Park, West Hungary) aims the exploration of relationships between the species diversity of many forest-dwelling organism groups and environmental conditions.

Considering macrofungi taxa, Örség National Park is one of the well-studied and most species rich regions in Hungary. Consequently, several studies have been published on macrofungi taxa from Örség; the most important ones are Vasas \& Locsmándi (1995), Zagyva (2000), Lukács et al. (2001), Bratek et al. (2003) and Siller (2003). Macrofungi species new to Hungary are being published from Örség National Park nowadays too. Hence, there is an emerging need for extensive surveys on macrofungi to get to know more about the diverse mycobiota of the region.

We aimed at providing fungi data for Örs-erdő Project, and getting a more detailed picture about the macrofungi community of the most frequent forest types of Örség National Park. 


\section{Materials \& Methods}

\section{Study sites}

This study has been carried out in Örség National Park, West Hungary (46 $51^{\circ}-55^{\prime}$ North, $16^{\circ} 06^{\prime}-26^{\prime}$ East, Fig. 1a). Örség National Park has an area of $440 \mathrm{~km}^{2}$; forest stands cover the majority $(80 \%)$ of the region (Dövényi 2010). Forests are rarely monodominant but more often mixed with great compositional diversity (Tímár et al. 2002). Woodlands are dominated by beech (Fagus sylvatica L.), sessile and pedunculate oak [Quercus petraea (Matuschka) Liebl. and $Q$. robur L.], hornbeam (Carpinus betulus L.) and Scots pine (Pinus sylvestris L.). The most frequent mixing trees are Norway maple (Acer platanoides L.), silver birch (Betula pendula Roth), sweet chestnut (Castanea sativa Mill.), hazelnut (Corylus avellana L.), Norway spruce (Picea abies (L.) Karst.), trembling poplar (Populus tremula L.), wild cherry (Prunus avium L.), red oak (Quercus rubra L.) and small-leaved lime (Tilia cordata Mill.).

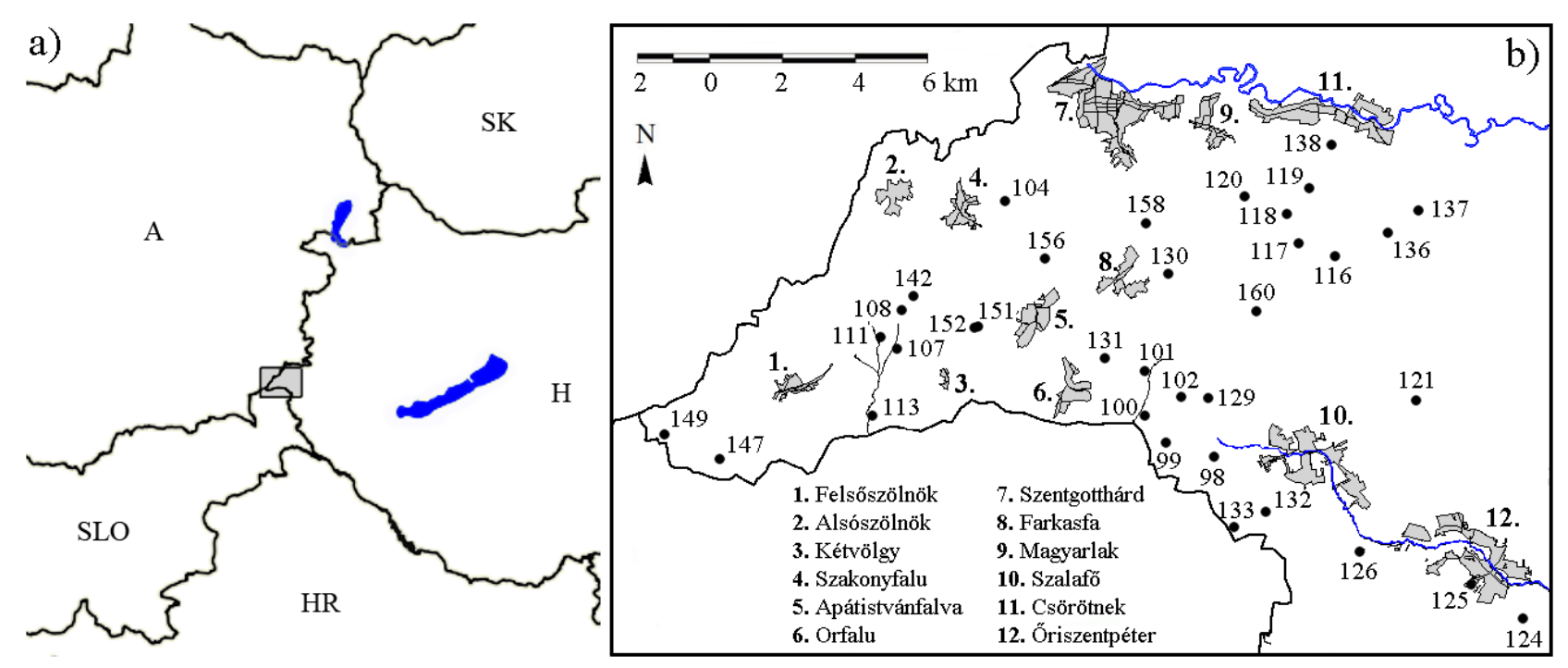

Fig. 1 - Borderline of West Hungary; the studied area is highlighted by grey (a). The geographical position of the 35 sampled plots (black dots) in Örség National Park; villages are numbered and shown by grey (b).

Örség is the most humid part of the country. The precipitation alters between 700 and 800 mm yearly. The annual mean temperature range is $9.0-9.5^{\circ} \mathrm{C}$. The landscape is divided into hills and wide valleys at the elevation range of 250-350 m above sea level. Bedrock consists of alluviated gravel and clay. Nutrient poor brown forest soils with pseudogley or lessivage are the most frequent soil types (Halász 2006, Dövényi 2010). Soil pH of stands is acidic; it tends to be altering from 3.9 through 4.4 (mean) up to 4.8 (Juhász et al. 2011).

In Örség National Park, we selected forest stands by stratified random sampling and using the Hungarian Forestry Database (Hungarian Central Agricultural Office, Forestry Directorate, www.nebih.gov). We chose 70-100 years old, spatially independent stands that are located in relatively plain areas and not influenced by water directly. We selected 35 stands randomly from these filtered ones representing a gradient along the characteristic tree species combinations of the region and then we assigned a $40 \mathrm{~m} \times 40 \mathrm{~m}$ plot in each stand. Fig. 1b and Table 1 show the geographical positions of plots. We carried out our field survey within these plots only. 
Table 1 Geographical coordinates of plots; name of nearby village is also shown.

\begin{tabular}{|c|c|c|c|}
\hline $\begin{array}{c}\text { Locality code } \\
\text { of plot }\end{array}$ & Geographical position & $\begin{array}{c}\text { Forest } \\
\text { Subcompartment }\end{array}$ & Village \\
\hline 98 & $4651^{\prime} 54.653^{\prime \prime} \mathrm{N}, 16$ 19' 15.296" E & $15 / \mathrm{L}$ & Szalafö 1 \\
\hline 99 & $4652^{\prime} 05.690^{\prime \prime} \mathrm{N}, 1618^{\prime} 12.649 " \mathrm{E}$ & $13 / \mathrm{I}$ & Szalafó 2 \\
\hline 100 & $4652^{\prime} 28.150^{\prime \prime} \mathrm{N}, 1617^{\prime} 43.240^{\prime \prime} \mathrm{E}$ & $12 / \mathrm{M}$ & Szalafö 3 \\
\hline 101 & 46 53'05.110" N, $1617^{\prime} 46.681^{\prime \prime} \mathrm{E}$ & $4 / \mathrm{A}$ & Orfalu 1 \\
\hline 102 & $4652^{\prime} 46.837^{\prime \prime} \mathrm{N}, 1618^{\prime} 29.870^{\prime \prime} \mathrm{E}$ & $3 / \mathrm{F}$ & Szalafö 4 \\
\hline 104 & $4655^{\prime} 33.982^{\prime \prime} \mathrm{N}, 1614^{\prime} 33.891^{\prime \prime} \mathrm{E}$ & $15 / \mathrm{G}$ & Szentgotthárd 1 \\
\hline 107 & $4653^{\prime} 19.188^{\prime \prime} \mathrm{N}, 1612^{\prime} 23.680^{\prime \prime} \mathrm{E}$ & $35 / \mathrm{G}$ & Kétvölgy 1 \\
\hline 108 & $4653^{\prime} 54.781^{\prime \prime} \mathrm{N}, 1612^{\prime} 25.385^{\prime \prime} \mathrm{E}$ & $4 / \mathrm{E}$ & Alsószölnök 1 \\
\hline 111 & $4653^{\prime} 30.615^{\prime \prime} \mathrm{N}, 1611^{\prime} 59.816^{\prime \prime} \mathrm{E}$ & $64 / J$ & Felsőszölnök 1 \\
\hline 113 & $4652^{\prime} 20.415^{\prime \prime} \mathrm{N}, 1611^{\prime} 50.458^{\prime \prime} \mathrm{E}$ & $50 / \mathrm{D}$ & Kétvölgy 2 \\
\hline 116 & 46 54' 55.997" N, 16 21' 42.780" E & $8 / \mathrm{F}$ & Csörötnek 1 \\
\hline 117 & $4655^{\prime} 06.374^{\prime \prime} \mathrm{N}, 1620^{\prime} 55.250^{\prime \prime} \mathrm{E}$ & $5 / \mathrm{E}$ & Csörötnek 2 \\
\hline 118 & $4655^{\prime} 31.548^{\prime \prime} \mathrm{N}, 1620^{\prime} 40.027^{\prime \prime} \mathrm{E}$ & $3 / \mathrm{E}$ & Csörötnek 3 \\
\hline 119 & $4655^{\prime} 59.289^{\prime \prime} \mathrm{N}, 1621^{\prime} 03.414^{\prime \prime} \mathrm{E}$ & 43/B & Csörötnek 4 \\
\hline 120 & $4655^{\prime} 45.747^{\prime \prime} \mathrm{N}, 1619^{\prime} 40.323^{\prime \prime} \mathrm{E}$ & $2 / \mathrm{F}$ & Magyarlak \\
\hline 121 & $4652^{\prime} 50.779^{\prime \prime} \mathrm{N}, 1623^{\prime} 31.846 " \mathrm{E}$ & $32 / \mathrm{K}$ & Öriszentpéter 1 \\
\hline 124 & $4649^{\prime} 40.442^{\prime \prime} \mathrm{N}, 1626^{\prime} 00.453^{\prime \prime} \mathrm{E}$ & $10 / \mathrm{C}$ & Öriszentpéter 2 \\
\hline 125 & $4650^{\prime} 09.071 " \mathrm{~N}, 1624^{\prime} 52.290 " \mathrm{E}$ & $61 / \mathrm{A}$ & Öriszentpéter 3 \\
\hline 126 & $4650^{\prime} 35.277^{\prime \prime} \mathrm{N}, 1622^{\prime} 27.295^{\prime \prime} \mathrm{E}$ & $25 / \mathrm{D}$ & Öriszentpéter 4 \\
\hline 129 & $4652^{\prime} 47.693 " \mathrm{~N}, 1619^{\prime} 05.507^{\prime \prime} \mathrm{E}$ & $10 / \mathrm{F}$ & Szalafó 5 \\
\hline 130 & 46 54' 34.661" N, 16 18' 08.796" E & $34 / \mathrm{B}$ & Szentgotthárd 2 \\
\hline 131 & $4653^{\prime} 17.735^{\prime \prime} \mathrm{N}, 1616^{\prime} 49.926^{\prime \prime} \mathrm{E}$ & $2 / \mathrm{H}$ & Orfalu 2 \\
\hline 132 & 46 51'06.913" N, 16 20' 22.909" E & $64 / \mathrm{C}$ & Szalafö 6 \\
\hline 133 & $4650^{\prime} 52.490^{\prime \prime} \mathrm{N}, 1619^{\prime} 43.349^{\prime \prime} \mathrm{E}$ & $66 / \mathrm{A}$ & Szalafó 7 \\
\hline 136 & $4655^{\prime} 18.223^{\prime \prime} \mathrm{N}, 1622^{\prime} 49.107^{\prime \prime} \mathrm{E}$ & 20/B & Csörötnek 5 \\
\hline 137 & $4655^{\prime} 39.989^{\prime \prime} \mathrm{N}, 1623^{\prime} 28.937^{\prime \prime} \mathrm{E}$ & $3 / \mathrm{C}$ & Rábagyarmat \\
\hline 138 & $4656^{\prime} 33.435^{\prime \prime} \mathrm{N}, 1621^{\prime} 33.252^{\prime \prime} \mathrm{E}$ & $41 / \mathrm{D}$ & Csörötnek 6 \\
\hline 142 & 46 54'08.387" N, 16 12' 42.110" E & 4/D & Alsószölnök 2 \\
\hline 147 & $4651^{\prime} 35.705^{\prime \prime} \mathrm{N}, 1608^{\prime} 39.744^{\prime \prime} \mathrm{E}$ & $6 / \mathrm{B}$ & Felsőszölnök 2 \\
\hline 149 & 46 51' 54.429" N, $1607^{\prime} 23.460 " \mathrm{E}$ & $2 / \mathrm{F}$ & Felsőszölnök 3 \\
\hline 151 & $4653^{\prime} 42.833^{\prime \prime} \mathrm{N}, 1614^{\prime} 05.108$ " E & $67 / \mathrm{C}$ & Szakonyfalu 1 \\
\hline 152 & $4653^{\prime} 40.821^{\prime \prime} \mathrm{N}, 1613^{\prime} 58.406 " \mathrm{E}$ & 24/D & Szakonyfalu 2 \\
\hline 156 & 46 54' 44.777" N, 16 15' 28.818" E & 33/A & Apátistvánfalva \\
\hline 158 & $4655^{\prime} 18.534^{\prime \prime} \mathrm{N}, 1617^{\prime} 36.418^{\prime \prime} \mathrm{E}$ & $5 / \mathrm{B}$ & Szentgotthárd 3 \\
\hline 160 & 46 54'04.947" N, $1620^{\prime} 03.882^{\prime \prime} \mathrm{E}$ & $75 / \mathrm{J}$ & Szentgotthárd 4 \\
\hline
\end{tabular}

\section{Tree species compositions and available substrata on sites}

In order to express tree species compositions we surveyed all the trees larger than $5 \mathrm{~cm}$ in diameter at breast height $(\mathrm{DBH})$ within the $40 \mathrm{~m} \times 40 \mathrm{~m}$ plots. We registered the identity of tree species, and the DBH and height of each tree individual. We computed the volume of tree individuals by species specific equations using DBH and tree height (Sopp \& Kolozs 2000). We calculated the percentage composition of frequent tree species for each plot by using the relative volume of tree species. Based on this, we classified each plot into 6 stand types. We summarized these in Table 2 with the lists of rare tree species identified on the relating plots and represented by one or two individuals only.

Considering available substrata of macrofungi, it is to be noted that each of our surveyed forest stand are managed. Hence, the amount of dead wood is restricted to relatively low volumes (av. $19.5 \mathrm{~m}^{3}$ ) per hectare with the preponderance of cut stumps and thinner $(5-10 \mathrm{~cm}$ in diameter) branches. Large logs and snags are usually missing. In our opinion ectomycorrhizal fungi are not independent of litter conditions; they also have saprotrophic activity (Lindahl et al. 2005), so we registered litter types (leaf, needle or mixed litter) for each identified ectomycorrhizal and terricolous saprotrophic macrofungi to get a more comprehensive picture about their substrate preferences. 
Table 2 Stand types and characteristic tree species compositions surveyed in this study.

\begin{tabular}{|c|c|c|c|}
\hline $\begin{array}{l}\text { Stand } \\
\text { type }\end{array}$ & $\begin{array}{l}\text { Locality code of } \\
\text { included plots }\end{array}$ & $\begin{array}{l}\text { Range of relative volumes of } \\
\text { frequent trees }(\%)\end{array}$ & Rare tree species \\
\hline 1 & $\begin{array}{l}107,111,116, \\
136,147,149 \\
151\end{array}$ & $\begin{array}{l}F . \text { sylvatica }(94-46), Q . \text { petraea }(29-1), \\
C . \text { betulus }(22-15), P \text {. sylvestris }(9-0), P \text {. } \\
\text { abies }(8-0)\end{array}$ & $\begin{array}{l}\text { A. incana, A. platanoides, B. pendula, } C . \\
\text { sativa, } P \text {. tremula, } Q . \text { robur }\end{array}$ \\
\hline 2 & $\begin{array}{l}113,117,118 \\
152,158\end{array}$ & $\begin{array}{l}\text { F. sylvatica }(55-26), Q . \text { petraea }(38-11), \\
P . \text { sylvestris }(30-15), \text { B. pendula }(15-0), \\
P . \text { abies }(14-0), Q . \text { robur }(9-0), C . \\
\text { betulus }(6-3)\end{array}$ & C. sativa, C. avellana, $P$. avium \\
\hline 3 & $\begin{array}{l}99,119,120 \\
125,130,137\end{array}$ & $\begin{array}{l}Q . \text { petraea }(97-10), Q . \text { robur }(65-43), F \text {. } \\
\text { sylvatica }(20-0), C . \text { betulus }(13-3), P . \\
\text { avium }(4-1)\end{array}$ & $\begin{array}{l}\text { A. glutinosa, B. pendula, C. avellana, } P \text {. } \\
\text { abies, T. cordata }\end{array}$ \\
\hline 4 & $\begin{array}{l}100,104,129 \\
131,132,133 \\
138\end{array}$ & $\begin{array}{l}Q . \text { petraea }(77-53), P . \text { sylvestris }(26-7), \\
\text { C. betulus }(15-0), F . \text { sylvatica }(13-0), Q \text {. } \\
\text { cerris }(7-0)\end{array}$ & $\begin{array}{l}\text { B. pendula, } C \text {. avellana, } C . \text { sativa, } L . \\
\text { decidua, } P \text {. abies, } P . \text { avium, } T . \text { cordata, } Q . \\
\text { robur }\end{array}$ \\
\hline 5 & 142 & $\begin{array}{l}P . \text { abies }(50), P . \text { sylvestris }(23), C \text {. betulus } \\
(18), P . \text { tremula }(3), Q . \text { robur }(2)\end{array}$ & A. glutinosa, B. pendula, F. sylvatica \\
\hline 6 & $\begin{array}{l}98,101,102 \\
108,121,124 \\
126,156,160\end{array}$ & $\begin{array}{l}P . \text { sylvestris }(77-55), F \text {. sylvatica }(32-0) \text {, } \\
Q . \text { petraea }(28-0), T \text {. platyphyllos }(6-0), \\
\text { B. pendula }(5-0), P . \text { abies }(5-0)\end{array}$ & $\begin{array}{l}\text { A. glutinosa, } C \text {. avellana, } C \text {. betulus, } C \text {. } \\
\text { monogyna, } P \text {. avium, } P \text {. pyraster, } P . \\
\text { tremula, } Q . \text { robur, } Q . \text { rubra, } S . \text { torminalis, } \\
\text { T. cordata, } U . \text { glabra }\end{array}$ \\
\hline
\end{tabular}

$A=$ Alnus, $A$. platanoides $=$ Acer platanoides, $B=$ Betula,$C=$ Carpinus, $C$. sativa $=$ Castanea sativa, $C$. avellana $=$ Corylus avellana, $C$. monogyna $=$ Crataegus monogyna, $F=$ Fagus, $L=$ Larix, $P$. abies $=$ Picea abies, $P$. avium $=$ Prunus avium, $P$. sylvestris $=$ Pinus sylvestris, $P$. tremula $=$ Populus tremula, $P$. pyraster $=$ Pyrus pyraster, $Q=$ Quercus, $S=$ Sorbus, $T=$ Tilia, $U=$ Ulmus

\section{Macrofungi surveys and conservation of specimens}

We registered all the macrofungi taxa belonging to phyla Basidiomycota (excluding most of Corticiaceae s.1.) and Ascomycota and develop sporocarps larger than $2 \mathrm{~mm}$. In order to find macrofungi of early and late fruiting alike, we performed three field surveys (I-III): one between $1^{\text {st }}$ and $8^{\text {th }}$ of August 2009 (I), and two others in spring (from $24^{\text {th }}$ until $31^{\text {st }}$ of May) (II) and autumn (between $19^{\text {th }}$ of September and $5^{\text {th }}$ of November) (III) 2010. We looked for sporocarps systematically within the $40 \mathrm{~m} \times 40 \mathrm{~m}$ plots on any kind of substrata: on soil, litter, dead or living wood (until two meters height), among mosses and on sporocarps of other fungi, etc. We stored dried specimens in fungarium to conserve sporocarps for further identification and proof. Drying was carried out by a fruit dryer machine. Specimens are available at Irén Siller, Szent István University, Budapest.

\section{Identification and nomenclature}

We performed species identifications in laboratory by using two optical microscopes (Labo America DN-200M and Zeiss Laboval 2/I/C) and applying lenses with 40× or 100× magnification powers, oil immersion technique and $10 \times$ or $15 \times$ eyepieces. We examined specimens (one sporocarp per specimen) in water or $2-10 \% \mathrm{KOH}$. When it was needed, we used special dyes like Melzer's reagent (for genera Cortinarius, Hebeloma, Mycena, etc.), Congo red (fixed in ammonium solution, for genus Inocybe) and cotton blue (for genus Ramaria). We measured length and width of 5-50 spores and calculated length/width ratio (Q-value). When it was necessary, we checked cystidia, basidia and structures of pileipellis too.

Sometimes we identified taxa at "sensu lato" level only due to hardships in separating species complexes (e.g. Schizopora paradoxa s.l. and some Cortinarius taxa) under microscope. We had identification problems with some Cortinarius and one Hydnum species because of the incomplete clarification of their taxonomy. In these cases we finished the identifications at genus level. 
We determined the identity and nomenclature of collected taxa by using the following monographs and books: Breitenbach \& Kränzlin (1984, 1986, 1991, 1995, 2000), Jülich (1984), Moser \& Jülich (1985), Kuyper (1986), Bas et al. (1990, 1995, 1999), Ryvarden \& Gilbertson (1993, 1994), Courtecuisse \& Duhem (1994), Galli (1996, 2001, 2006), Hansen \& Knudsen (1997, 2000), Sarnari (1998, 2005), Basso (1999), Heilmann-Clausen et al. (2000), Krieglsteiner (2000a, b, 2001, 2003), Ladurner \& Simonini (2003), Robich (2003), Bernicchia (2005), Vesterholt (2005), Christan (2008), Consiglio \& Setti (2008), Hausknecht (2009), Bernicchia \& Gorjón (2010), Krieglsteiner \& Gminder (2010) and Knudsen \& Vesterholt (2012). Sometimes we needed special literature for some identifications: Kobayasi (1941), Kobayasi \& Shimizu (1982), Brandrud et al. (1990, 1992, 1994, 1998), Bidaud et al. (2000), Bidaud et al. (2001, 2008, 2010), Bidaud et al. (2002-2004), Wagner \& Fischer (2002), Consiglio et al. (2003-2007), Huhtinen \& Ruotsalainen (2006), Miettinen et al. (2006), Niskanen (2008), Tomšovský (2008), Bello et al. (2009), Larsson et al. (2009), Roberts (2009), Carbone \& van Vooren (2010), Saar (2010), Olariaga et al. (2012) and Ghyselinck (2013).

In most cases we followed MycoBank (www.mycobank.org, assessed between $19^{\text {th }}$ and $20^{\text {th }}$ of April 2013) and more rarely Knudsen \& Vesterholt (2012) to verify the legitimate scientific name of collected macrofungi taxa. In the same time we used Index Fungorum (www.indexfungorum.org) to get abbreviated reference for each identified species.

\section{Checklist}

The species list is arranged alphabetically. After the Latin name of each taxon we indicate the abbreviated name of their author, following Kirk \& Ansell (1992), a suitable reference, the legitimate name of their family, the location(s) where they occurred (based on Table 1) and their preferred stand type(s) (detailed in Table 2) and substrata. We show the time of field survey(s) in brackets, indicated by Roman numerals (I-III), after the name of each location. We provide also a unique collection code (ORS-ERDO) with number and some microscopic features for taxa that are new to Hungary or were identified at genus level only. New species to Hungary are marked by an asterisk (*); the underlined ones are red-listed.

\section{Results}

In this study, we registered 13447 records in total and deposited 1604 specimens in fungarium. We fixed the vast majority of records $(11657 \mathrm{pc}$, ca. 87\%) during the third field survey between September and November 2010 due to the summer precipitation had been far above average. We stored a total of 1341 (ca. 10\%) records in August 2009 and 438 (ca. 3\%) in May 2010. Now, we list altogether 726 macrofungi taxa representing 214 genera, 84 classes and 2 phyla (Asco- and Basidiomycota). Registered taxa belonging to phylum Basidiomycota (654 species and 174 genera) were predominant over taxa of the phylum Ascomycota (71 species and 40 genera). Approximately one third (264, ca. 36\%) of all taxa were rare, i.e. represented by a single occurrence only. Sixty-one macrofungi species are new to the mycobiota of Hungary; 48 species are included in the proposed Hungarian Red List (Rimóczi et al. 1999). The three highest threat categories [such as Extinct (0), Critically Endangered (1) and Endangered (2)] were taken into consideration only.

\section{List of collected macrofungi taxa}

Agaricus essettei Bon, Docums. Mycol. 13(49): 56, 1983, Agaricaceae, found in plot Alsószölnök 2 (III), Öriszentpéter 1 (I) and 4 (III), in stand type 5 and 6, on mixed (needle and leaf) litter.

Agaricus semotus Fr., Monogr. Hymenomyc. Suec. (Upsaliae) 2(2): 347, 1863, Agaricaceae, found in plot Alsószölnök 2 (III) and Szakonyfalu 1 (III), in stand type 1 and 5, on mixed (needle and leaf) litter. 
Agaricus sylvaticus Schaeff., Fung. Bavar. Palat. 4: 62, 1774, Agaricaceae, found in plot Alsószölnök 2 (III), in stand type 5, on mixed (needle and leaf) litter.

Agrocybe firma (Peck) Singer, Revue Mycol. (Paris) 5: 11, 1940, Strophariaceae, found in plot Csörötnek 1 (III), in stand type 1, on leaf litter and decaying wood of Fagus sylvatica and Carpinus betulus.

Agrocybe praecox (Pers.) Fayod, Annls Sci. Nat. Bot., sér. 7, 9: 358, 1889, Strophariaceae, found in plot Csörötnek 1, 3 (II) and Felsőszölnök 3 (II), in stand type 1 and 2, on leaf litter and decaying wood of Fagus sylvatica.

Agrocybe vervacti (Fr.) Singer, Beih. Bot. Cbl. Abt. B 56: 167, 1936, Strophariaceae, found in plot Rábagyarmat (III), in stand type 3, on leaf litter.

Aleurodiscus disciformis (DC.) Pat., Bull. Soc. Mycol. Fr. 10: 80, 1894, Stereaceae, found in plot Alsószölnök 1 (III), Csörötnek 4 (I, III), 5 (III), Felsőszölnök 3 (II), Magyarlak (III), Orfalu 2 (III), Öriszentpéter 3 (III), Rábagyarmat (II), Szalafö 3 (I, III), 5 (II, III) and Szentgotthárd 3 (III), in stand type 1-4 and 6, on bark of living Quercus petraea.

Amanita argentea Huijsm., Bull. Soc. Mycol. Fr. 75: 14, 1959, Amanitaceae, found in plot Csörötnek 5 (I), Kétvölgy 2 (I), Öriszentpéter 2 (I, III) and Szalafö 2, 3, 6 (I), in stand type 1-4 and 6, mainly on leaf, sometimes on mixed (needle and leaf) litter.

Amanita caesarea (Scop.) Pers., Syn. Meth. Fung. (Göttingen) 2: 252, 1801, Amanitaceae, found in plot Csörötnek 4 (I) and Szalafö 2 (I), in stand type 3, mainly on leaf, sometimes on mixed (needle and leaf) litter.

Amanita citrina (Schaeff.) Pers., Syn. Meth. Fung. (Göttingen) 1: 251, 1801, Amanitaceae, found in plot Alsószölnök 1 (III), Apátistvánfalva (III), Csörötnek 5, 6 (III), Felsöszölnök 3 (III), Kétvölgy 1 (III), Orfalu 1 (III), Rábagyarmat (III), Szakonyfalu 1 (III), Szalafó 1-3, 7 (III) and Szentgotthárd 4 (I, III), in stand type 1, 3, 4 and 6, mainly on mixed (needle and leaf), sometimes on leaf litter.

Amanita eliae Quél., Mém. Soc. Émul. Montbéliard, sér. 2, 5: 230, 1872, Amanitaceae, found in plot Szentgotthárd 2 (I), in stand type 3, on leaf litter.

Amanita excelsa (Fr.) Bertill., Dict. Encyclop. Sci. Medic. 13: 499, 1866, Amanitaceae, found in plot Csörötnek 2 (II, III), Magyarlak (I), Öriszentpéter 1 (II), Szakonyfalu 1 (III), Szalafö 1 (I, III) and Szalafö 2 (I), in stand type 1-3 and 6, on mixed (needle and leaf) litter.

Amanita franchetii (Boud.) Fayod, Annls Sci. Nat., Bot., sér. 7, 9: 316, 1889, Amanitaceae, found in plot Csörötnek 1 (III), in stand type 1, on leaf litter.

Amanita fulva (Fr.) Fr., Observ. Mycol. (Havniae) 1: 2, 1815, Amanitaceae, found in plot Orfalu 1 (I), Szalafö 1 (I, III) and Szentgotthárd 4 (I), in stand type 6, on mixed (needle and leaf) litter.

Amanita gemmata (Fr.) Bertill., Essai Crypt. Exot. (Paris) 3: 496, 1866, Amanitaceae, found in plot Alsószölnök 1 (I), Csörötnek 2 (III) and Szalafö 1 (III), in stand type 2 and 6, on mixed (needle and leaf) litter.

Amanita muscaria (L.) Lam., Encycl. Méth. Bot. (Paris) 1(1): 111, 1783, Amanitaceae, found in plot Alsószölnök 1 (III) and Kétvölgy 2 (III), in stand type 2 and 6, on mixed (needle and leaf) litter.

Amanita phalloides (Fr.) Link, Handbuch zur Erkennung der nutzbarsten und am häufigsten vorkommenden Gewächse: 272, 1833, Amanitaceae, found in plot Alsószölnök 2 (I, III), Csörötnek 3 (III), 5 (I), Orfalu 2 (I), Öriszentpéter 2, 3 (III) and Szentgotthárd 2 (I), in stand type 1-6, mainly on leaf, sometimes on mixed (needle and leaf) litter.

Amanita porphyria Alb. \& Schwein., Consp. fung. (Leipzig): 142, 1805, Amanitaceae, found in plot Szalafö 1 (III), in stand type 6, on mixed (needle and leaf) litter.

Amanita rubescens Pers., Tent. Disp. Meth. Fung. (Lipsiae): 71, 1797, Amanitaceae, found in plot Alsószölnök 1 (I, III), Csörötnek 1, 2, 4 (I), Felsőszölnök 1 (III), Magyarlak (I), Orfalu 1 (I), Öriszentpéter 2 (III), 3 (I, III), Rábagyarmat (I), Szakonyfalu 1 (III), Szalafö 1 (III), 2 (I, III), 5 (I), 6 (I), Szentgotthárd 1 (III) and 2, 3 (I), in stand type 1-4 and 6, mainly on leaf, sometimes on mixed (needle and leaf) litter. 
Amanita vaginata (Bull.) Lam., Encycl. Méth. Bot. (Paris) 1(1): 109, 1783, Amanitaceae, found in plot Kétvölgy 2 (I) and Orfalu 2 (I), in stand type 2 and 4, on mixed (needle and leaf) litter.

Ampulloclitocybe clavipes (Pers.) Redhead, Lutzoni, Moncalvo \& Vilgalys, Mycotaxon 83: 36, 2002, Hygrophoraceae, found in plot Öriszentpéter 4 (III) and Szalafö 1 (III), in stand type 6 , among mosses, sometimes on mixed (needle and leaf) litter.

Annulohypoxylon cohaerens (Pers.) Y.-M. Ju, J.D. Rogers \& H.-M. Hsieh, Mycologia 97(4): 857, 2005, Xylariaceae, found in plot Kétvölgy 1 (I), Orfalu 1 (I) and Szakonyfalu 2 (I), in stand type 1, 2 and 6, on decaying wood of Fagus sylvatica.

Annulohypoxylon multiforme (Fr.) Y.-M. Ju, J.D. Rogers \& H.-M. Hsieh, Mycologia 97(4): 859, 2005, Xylariaceae, found in plot Csörötnek 6 (I), Öriszentpéter 1, 3 (I) and Szentgotthárd 2 (I), in stand type 3, 4 and 6, on decaying wood of Carpinus betulus and Quercus petraea.

Anthina flammea* (Jungh.) Fr., Syst. Mycol. (Lundae) 3: 283, 1832, incertae sedis, found in plot Csörötnek 5 (III) and Szentgotthárd 2 (III), in stand type 1 and 3, on leaf litter. Specimen examined: ORS-ERDO 136-56-1 (September 10, 2010). Anamorphs are known only; anamorphs form bright flame-like spines of aggregated mycelium; hyphae 3.0-4.0 $\mu \mathrm{m}$ wide, pigmented, without clamp connections.

Antrodia albida (Fr.) Donk, Persoonia 4(3): 339, 1966, Fomitopsidaceae, found in plot Csörötnek 1, 2 (III), 4 (II), Kétvölgy 1 (III), Szakonyfalu 1 (III), Szalafő 1 (III) and Szentgotthárd 2, 3 (III), in stand type 1-3 and 6, on decaying wood of Fagus sylvatica.

Antrodia heteromorpha (Fr.) Donk, Persoonia 4(3): 339, 1966, Fomitopsidaceae, found in plot Csörötnek 4 (I), in stand type 3, on decaying wood of Picea abies.

Antrodia malicola (Berk. \& M.A. Curtis) Donk, Persoonia 4(3): 339, 1966, Fomitopsidaceae, found in plot Csörötnek 1 (I, III), 3 (I), 6 (I), Felsőszölnök 1 (III), 2 (I), 3 (II), Kétvölgy 1 (I, III) and Szentgotthárd 4 (I), in stand type 1, 2, 4 and 6, on decaying wood of Fagus sylvatica.

Antrodia vaillantii (DC.) Ryvarden, Norw. Jl. Bot. 20(1): 8, 1973, Fomitopsidaceae, found in plot Szakonyfalu 1 (III), in stand type 1, on decaying wood of Pinus sylvestris.

Antrodiella faginea* Vampola \& Pouzar, Czech Mycol. 49(1): 25, 1996, Phanerochaetaceae, found in plot Csörötnek 1 (I), 2 (III), 4 (I), Öriszentpéter 2 (III), Szakonyfalu 1 (I), Szalafö 1 (III) and Szentgotthárd 3 (I), in stand type 1-3 and 6, on dead wood of broadleaved trees. Specimen examined: ORS-ERDO 124-25-1 (September 20, 2010). Spores 3.2-4.3 × 2.2 $\mu \mathrm{m}$, av. $4.0 \times 2.2 \mu \mathrm{m}, \mathrm{Qav}=1.883, \mathrm{n}=6$; generative hyphae with clamps, $2.2 \mu \mathrm{m}$ in diameter, skeletal hyphae $4.3 \mu \mathrm{m}$ wide.

Antrodiella fragrans (A. David \& Tortič) A. David \& Tortič, Cryptog. Mycol. 7(1): 4, 1986, Phanerochaetaceae, found in plot Apátistvánfalva (I), Csörötnek 1, 3 (I, III), 4 (III), 5 (I, III), 6 (I), Felsőszölnök 1-3 (I, III), Orfalu 2 (I), Öriszentpéter 1 (III), Szakonyfalu 1, 2 (IIII), Szalafö 1, 3, 4 (III), 5 (II, III), 6 (I-III), 7 (III) and Szentgotthárd 2, 4 (I-III), in stand type 1-4 and 6, on dead wood of broadleaved trees.

Antrodiella pallescens (Pilát) Niemelä \& Miettinen, Mycotaxon 96: 227, 2006, Phanerochaetaceae, found in plot Alsószölnök 2 (I), Csörötnek 1, 2 (I) and Felsőszölnök 1, 2 (I), in stand type 1, 2 and 5, on decaying wood of Fagus sylvatica and Carpinus betulus.

Antrodiella romellii* (Donk) Niemelä, Karstenia 22: 11, 1982, Phanerochaetaceae, found in plot Csörötnek 3-5 (I), in stand type 1-3, on decaying wood of Fagus sylvatica and Quercus petraea. Specimen examined: ORS-ERDO 15/18 (August 3, 2009). Spores 3.6-5.4 × 1.8 $\mu \mathrm{m}$; hyphae with clamps, $3.6 \mu \mathrm{m}$ wide; cystidia not observed.

Antrodiella serpula (P. Karst.) Spirin \& Niemelä, Mycotaxon 96: 231, 2006, Phanerochaetaceae, found in plot Csörötnek 2 (I) and Szakonyfalu 1 (III), in stand type 1 and 2, on decaying wood of Fagus sylvatica.

Armillaria lutea Gillet, Hyménomycètes (Alençon): 93, 1874, Physalacriaceae, found in plot Csörötnek 1, 5, 6 (III), Felsőszölnök 2, 3 (III), Kétvölgy 2 (III), Orfalu 2 (III), Rábagyarmat (III), Szalafó 7 (III) and Szentgotthárd 1, 3 (III), in stand type 1-4, on soil or on (buried) dead wood of broadleaved trees. 
Armillaria mellea (Vahl) P. Kumm., Führ. Pilzk. (Zwickau): 134, 1871, Physalacriaceae, found in plot Csörötnek 1 (III), in stand type 1, on dead wood of broadleaved trees.

Armillaria ostoyae (Romagn.) Herink, Sympozium o Václavce Obecné Armillaria mellea (Vahl ex Fr.) Kumm. (Brno): 42, 1973, Physalacriaceae, found in plot Szalafö 4 (III), in stand type 6, on needle litter and decaying wood of Pinus sylvestris.

Artomyces pyxidatus (Pers.) Jülich, Biblthca Mycol. 85: 399, 1982, Amylostereaceae, found in plot Felsőszölnök 2 (III), in stand type 1, on decaying wood of Fagus sylvatica.

Ascocoryne cylichnium (Tul.) Korf, Phytologia 21(4): 202, 1971, Heliotaceae, found in plot Csörötnek 1 (III), Kétvölgy 2 (III), Szalafö 2 (III) and Szentgotthárd 2 (III), in stand type 13 , on dead wood of broadleaved trees.

Ascocoryne sarcoides (Jacq.) J.W. Groves \& D.E. Wilson, Taxon 16(1): 40, 1967, Heliotaceae, found in plot Szakonyfalu 1 (III), Szalafö 5, 7 (III) and Szentgotthárd 2 (I), in stand type 1, 3 and 4, on decaying wood of Quercus petraea.

Ascotremella faginea* (Peck) Seaver, Mycologia 22(2): 53, 1930, Helotiaceae, found in plot Csörötnek 1 (I, III), in stand type 1 , on dead wood of broadleaved trees. Specimen examined: ORS-ERDO 23/13 (August 4, 2009). Spores 6.5-8.6 × 3.2-4.3 $\mu \mathrm{m}$, av. $7.6 \times 3.8$ $\mu \mathrm{m}, \mathrm{Qav}=2.017, \mathrm{n}=10$, ellipsoid with two oil drops; asci on av. $75.3 \times 8.6 \mu \mathrm{m}, 8$-spored, without iodine reaction; paraphyses filamentous.

Asterophora lycoperdoides (Bull.) Ditmar, J. Bot. (Schrader) 3: 56, 1809, Lyophyllaceae, found in plot Csörötnek 2 (III), Orfalu 2 (I), Öriszentpéter 2 (I), 2 (III), Szakonyfalu 1 (III), Szalafö 1 (III), 2 (I, III) and Szentgotthárd 3 (I), in stand type 1-4 and 6, on sporocarp of Russula nigricans or $R$. acrifolia.

Atheniella flavoalba (Fr.) Redhead, Moncalvo, Vilgalys, Desjardin, B.A. Perry, Index Fungorum, 14: 1, 2012, Porotheleaceae, found in plot Öriszentpéter 3, 4 (III), Szakonyfalu 2 (III) and Szalafó 1, 3-5 (III), in stand type 2-4 and 6, on mixed (needle and leaf) litter, sometimes among mosses.

Auricularia auricula-judae (Bull.) Quél., Enchir. fung. (Paris): 207, 1886, Auriculariaceae, found in plot Csörötnek 1 (III), Felsőszölnök 2 (I, III), 3 (I), Szakonyfalu 2 (II, III), Szalafö 3, 5 (II, III), 6 (III) and Szentgotthárd 4 (I-III), in stand type 1, 2, 4 and 6, on dead wood of broadleaved trees.

Auriscalpium vulgare Gray, Nat. Arr. Brit. Pl. (London) 1: 650, 1821, Auriscalpiaceae, found in plot Alsószölnök 1, 2 (III), Apátistvánfalva (III), Csörötnek 1-3, 5, 6 (III), Kétvölgy 2 (III), Orfalu 1 (I, III), 2 (III), Öriszentpéter 1-4 (III), Szakonyfalu 1 (I, III), 2 (II, III), Szalafö 1 (II, III), 3, 4, 6, 7 (III), Szentgotthárd 1 (III) and 3, 4 (I, III), in stand type 1-6, on fallen cones of Pinus sylvestris.

Baeospora myosura (Fr.) Singer, Revue Mycol. (Paris) 3: 193, 1938, Cyphellaceae, found in plot Alsószölnök 1, 2 (III), Apátistvánfalva (III), Csörötnek 1, 3 (III), Kétvölgy 2 (III), Orfalu 1 (III), Öriszentpéter 2, 4 (III), Szakonyfalu 1, 2 (III), Szalafö 1, 3 (III) and Szentgotthárd 4 (III), in stand type 1, 2 and 4-6, on fallen cones.

Bertia moriformis (Tode) De Not., G. Bot. Ital. 1(1): 335, 1844, Bertiaceae, found in plot Szakonyfalu 2 (I) and Szalafö 4 (I), in stand type 2 and 6, on decaying wood of Fagus sylvatica.

Biscogniauxia nummularia (Bull.) Kuntze, Revis. Gen. Pl. (Leipzig) 2: 398, 1891, Xylariaceae, found in plot Alsószölnök 1 (I), Csörötnek 1-6 (I), Felsőszölnök 1-3 (I), Kétvölgy 1 (I), Magyarlak (I), Rábagyarmat (I), Szakonyfalu 1 (I), Szalafö 4, 6, 7 (I) and Szentgotthárd 4 (I), in stand type 1-4 and 6, on dead wood of broadleaved trees.

Bisporella citrina (Batsch) Korf \& S.E. Carp., Mycotaxon 1: 58, 1974, Helotiaceae, found in plot Szakonyfalu 2 (I) and Szentgotthárd 2 (I), in stand type 2 and 3, on decaying wood of Fagus sylvatica and Quercus petraea.

Bjerkandera adusta (Willd.) P. Karst., Meddn. Soc. Fauna Flora Fenn. 5: 38, 1879, Meruliaceae, found in plot Csörötnek 1 (I, II), 3 (I), 5 (III), Felsőszölnök 3 (I, III), Kétvölgy 2 (I) and 
Öriszentpéter 3 (III), in stand type 1-3, on decaying wood of Fagus sylvatica and Carpinus betulus.

Bjerkandera fumosa (Pers.) P. Karst., Meddn. Soc. Fauna Flora Fenn. 5: 38, 1879, Meruliaceae, found in plot Felsőszölnök 3 (III), in stand type 1, on decaying wood of Fagus sylvatica.

Bolbitius pluteoides M.M. Moser, Fung. Rar. Icon. Col. 7: 27, 1978, Bolbitiaceae, found in plot Szentgotthárd 1 (III), in stand type 4, on dead wood of broadleaved trees.

Bolbitius reticulatus (Pers.) Ricken, Die Blätterpilze 1: 68, 1915, Bolbitiaceae, found in plot Felsöszölnök 3 (I), in stand type 1, on leaf litter.

Boletus edulis Bull., Herb. Fr. 2: tab. 60, 1782, Boletaceae, found in plot Alsószölnök 2 (III), Szakonyfalu 1 (III) and Szalafö 2, 3 (III), in stand type 1 and 3-5, mainly on leaf, sometimes on mixed (needle and leaf) litter.

Boletus reticulatus Schaeff., Fung. Bavar. Palat. 4: 78, 1774, Boletaceae, found in plot Öriszentpéter 3 (I) and Szalafö 5 (II), in stand type 3 and 4, on leaf litter.

Bulgaria inquinans (Pers.) Fr., Syst. Mycol. (Lundae) 2: 167, 1822, Bulgariaceae, found in plot Csörötnek 6 (I), Szalafö 1 (III) and Szentgotthárd 2 (I), in stand type 3, 4 and 6, on decaying wood of Quercus petraea.

Byssomerulius corium (Pers.) Parmasto, Eesti NSV Tead. Akad. Toim., Biol. seer 16(4): 383, 1967, Phanerochaetaceae, found in plot Alsószölnök 2 (III), Csörötnek 1 (III), Öriszentpéter 2-4 (III), Szentgotthárd 1 (III) and 2 (I, III), in stand type 1 and 3-6, on decaying wood of Fagus sylvatica and Carpinus betulus.

Callistosporium luteo-olivaceum (Berk. \& M.A. Curtis) Singer, Lloydia 89: 117, 1946, Tricholomataceae, found in plot Alsószölnök 2 (III) and Öriszentpéter 1 (III), in stand type 5 and 6, on decaying wood of Pinus sylvestris.

Calocera cornea (Batsch) Fr., Stirp. Agri. Femison. 5: 67, 1827, Dacrymycetaceae, found in plot Csörötnek 5 (III), Felsőszölnök 3 (I), Öriszentpéter 3 (I), Rábagyarmat (I) and Szakonyfalu 1 (III), in stand type 1 and 3, on dead wood of broadleaved trees.

Calocera furcata (Fr.) Fr., Compt. Rend. Assoc. Franç. Avancem. Sci. 9: 670, 1881, Dacrymycetaceae, found in plot Alsószölnök 1 (I), Csörötnek 1, 2, 5 (I), 5 (III), Felsőszölnök 3 (I, III), Öriszentpéter 4 (III), Rábagyarmat (III), Szakonyfalu 1 (III), Szalafö 2, 5 (III), 6 (II, III), Szentgotthárd 2 (II) and 3, 4 (I), in stand type 1-4 and 6, on dead wood of broadleaved trees.

Calocera viscosa (Pers.) Fr., Syst. mycol. (Lundae) 1: 486, 1827, Dacrymycetaceae, found in plot Alsószölnök 1 (III), Csörötnek 4 (III), Orfalu 1 (I), Rábagyarmat (III), Szakonyfalu 1 (III), Szentgotthárd 3 (I) and 4 (III), in stand type 1-3 and 6, on decaying wood of Pinus sylvestris.

Cantharellula umbonata (J.F. Gmel.) Singer, Revue Mycol., (Paris) 1: 281, 1936, Hygrophoraceae, found in plot Öriszentpéter 4 (III), in stand type 6, on buried decaying wood of Quercus petraea.

Cantharellus cibarius Fr., Syst. Mycol. (Lundae) 1: 318, 1821, Cantharellaceae, found in plot Alsószölnök 1 (I, III), Csörötnek 4 (II), Felsőszölnök 1-3 (I), 3 (III), Kétvölgy 1 (I-III), Orfalu 1, 2 (I), Szakonyfalu 1 (I, III), Szalafö 1, 2 (I, III), 3 (II, III) and 5 (I), in stand type 1, 3, 4 and 6, mainly on mixed (needle and leaf), sometimes on leaf litter.

Ceriporia purpurea (Fr.) Donk, Proc. K. Ned. Akad. Wet., ser. C, Biol. Med. Sci. 74(1): 28, 1971, Phanerochaetaceae, found in plot Csörötnek 2 (II), 4 (I) and Szalafö 3 (II), in stand type 24 , on dead wood of broadleaved trees.

Ceriporiopsis gilvescens (Bres.) Dom., Acta Soc. Bot. Pol. 32(4): 731, 1963, Phanerochaetaceae, found in plot Szalafö 6 (III), in stand type 4, on decaying wood of Quercus petraea.

Ceriporiopsis mucida (Pers.) Gilb. \& Ryvarden, Mycotaxon 22: 364, 1985, Phanerochaetaceae, found in plot Alsószölnök 2 (I), Apátistvánfalva (I), Csörötnek 3 (II), 6 (I), Öriszentpéter 1 (I) and Szalafö 3 (III), in stand type 2 and 4-6, on dead wood of broadleaved and coniferous trees. 
Cerrena unicolor (Bull.) Murrill, J. Mycol. 9(2): 91, 1903, Polyporaceae, found in plot Felsőszölnök 2 (I-III), in stand type 1, on living Fagus sylvatica trees.

Chalciporus piperatus (Bull.) Bataille, Bull. Soc. Hist. Nat. Doubs 15: 39, 1908, Boletaceae, found in plot Alsószölnök 1 (III), in stand type 6, on mixed (needle and leaf) litter.

Cheilymenia crucipila (Cooke \& W. Phillips) Le Gal, Discom. de Madagascar: 111, 1954, Pyronemataceae, found in plot Öriszentpéter 4 (I), in stand type 6, on soil.

Chlorociboria aeruginascens (Nyl.) Kanouse ex C.S. Ramamurthi, Korf \& L.R. Batra, Mycologia 49(6): 858, 1957, Heliotaceae, found in plot Alsószölnök 1 (III), 2 (I, III), Csörötnek 2 (III) and Szakonyfalu 1 (III), in stand type 1, 2, 5 and 6, on dead wood of broadleaved and coniferous trees.

Chlorophyllum olivieri (Barla) Vellinga, Mycotaxon 83: 416, 2002, Agaricaceae, found in plot Alsószölnök 1 (III) and Öriszentpéter 1, 4 (III), in stand type 6, on mixed (needle and leaf) litter.

Chroogomphus rutilus (Schaeff.) O.K. Mill., Mycologia 56(4): 543, 1964, Gomphidiaceae, found in plot Apátistvánfalva (III), Öriszentpéter 2 (I, III) and Szakonyfalu 1 (III), in stand type 1 and 6 , on mixed (needle and leaf) litter.

Ciboria cf. amentacea (Balb.) Fuckel, Jb. Nassau. Ver. Naturk. 23-24: 311, 1870, Sclerotiniaceae, found in plot Rábagyarmat (III), in stand type 3, on leaf litter.

Claussenomyces prasinulus* (P. Karst.) Korf \& Abawi, Can. J. Bot. 49(11): 1882, 1971, Helotiaceae, found in plot Szakonyfalu 1 (I), in stand type 1, on decaying wood of Betula pendula. Specimen examined: ORS-ERDO 51/12 (August 8, 2009). Spores 11.1-13.4 × 3.2-4.7 $\mu \mathrm{m}$, av. $12.0 \times 3.8 \mu \mathrm{m}$, Qav $=3.138, \mathrm{n}=6$, cylindrical, with 3 septa; asci on av. $94.7 \times 7.9 \mu \mathrm{m}$; paraphyses forked.

Clavariadelphus pistillaris (L.) Donk, Meddn. Bot. Mus. Herb. Rijhs. Universit. Utrecht. 9: 72 , 1933, Clavariadelphaceae, found in plot Felsöszölnök 2 (III), in stand type 1, on leaf litter.

Clavulina cinerea (Bull.) J. Schröt., Krypt.-Fl. Schlesien (Breslau) 3.1(25-32): 443, 1888, Clavulinaceae, found in plot Alsószölnök 2 (III), Csörötnek 1-6 (III), Felsőszölnök 1-3 (III), Kétvölgy 2 (III), Magyarlak (III), Orfalu 1, 2 (III), Öriszentpéter 1, 4 (III), Rábagyarmat (III), Szakonyfalu 2 (III), Szalafö 5-7 (III) and Szentgotthárd 2, 3 (III), in stand type 1-6, mainly on leaf, sometimes on mixed (needle and leaf) litter.

Clavulina coralloides (L.) J. Schröt., Krypt.-Fl. Schlesien (Breslau) 3.1(25-32): 443, 1888, Clavulinaceae, found in plot Alsószölnök 2 (III), Apátistvánfalva (III), Csörötnek 1-6 (III), Felsőszölnök 2 (III), Kétvölgy 1, 2 (III), Magyarlak (III), Orfalu 1 (III), Öriszentpéter 1, 2, 4 (III), Rábagyarmat (III), Szakonyfalu 1 (III), 2 (I, III), Szalafó 1-3, 5, 6, 7 (III) and Szentgotthárd 2-4 (III), in stand type 1-6, mainly on leaf, sometimes on mixed (needle and leaf) litter.

Clavulina rugosa (Bull.) J. Schröt., Krypt.-Fl. Schlesien (Breslau) 3.1(25-32): 442, 1888, Clavulinaceae, found in plot Csörötnek 4 (III), Felsőszölnök 1-3 (III), Kétvölgy 1, 2 (III), Orfalu 2 (III), Öriszentpéter 1 (III), Szakonyfalu 2 (III) and Szalafö 3, 6, 7 (III), in stand type 1-4 and 6, mainly on leaf, sometimes on mixed (needle and leaf) litter.

Clitocybe candicans (Pers.) P. Kumm., Führ. Pilzk. (Zwickau): 122, 1871, Tricholomataceae, found in plot Apátistvánfalva (III), Csörötnek 1 (III), Felsőszölnök 2 (III), Kétvölgy 2 (III), Orfalu 1 (III), Szakonyfalu 1 (III), Szalafö 2 (III) and Szentgotthárd 4 (III), in stand type 13 and 6 , on mixed (needle and leaf) litter.

Clitocybe ditopa (Fr.) Gillet, Hyménomycètes (Alençon): 166, 1874, Tricholomataceae, found in plot Apátistvánfalva (III), Csörötnek 1, 6 (III), Kétvölgy 2 (III), Orfalu 1 (III), Szalafö 1, 3, 7 (III) and Szentgotthárd 1, 4 (III), in stand type 1, 2, 4 and 6, on mixed (needle and leaf) litter.

Clitocybe fragrans (With.) P. Kumm., Führ. Pilzk. (Zwickau): 121, 1871, Tricholomataceae, found in plot Csörötnek 6 (III) and Öriszentpéter 4 (III), in stand type 4 and 6, on leaf litter. 
Clitocybe metachroa (Fr.) P. Kumm., Führ. Pilzk. (Zwickau): 120, 1871, Tricholomataceae, found in plot Csörötnek 1, 6 (III), Szalafö 4 (III) and Szentgotthárd 1 (III), in stand type 1, 4 and 6, on mixed (needle and leaf) litter.

Clitocybe nebularis (Batsch) P. Kumm., Führ. Pilzk. (Zwickau): 124, 1871, Tricholomataceae, found in plot Csörötnek 5, 6 (III), Felsőszölnök 2, 3 (III), Kétvölgy 1, 2 (III), Orfalu 1 (III), Öriszentpéter 1, 3, 4 (III), Szakonyfalu 2 (III), Szalafö 5 (III) and Szentgotthárd 1, 2, 4 (III), in stand type 1-4 and 6, on mixed (needle and leaf) litter.

Clitocybe odora (Bull.) P. Kumm., Führ. Pilzk. (Zwickau): 121, 1871, Tricholomataceae, found in plot Csörötnek 1 (III) and Öriszentpéter 3, 4 (III), in stand type 1, 3 and 6, on leaf litter.

Clitocybe phaeophthalma (Pers.) Kuyper, Persoonia 11(3): 386, 1981, Tricholomataceae, found in plot Csörötnek 1, 6 (III), Szalafö 3 (III) and Szentgotthárd 4 (III), in stand type 1, 4 and 6, mainly on leaf, sometimes on mixed (needle and leaf) litter.

Clitocybe phyllophila (Pers.) P. Kumm., Führ. Pilzk. (Zwickau): 122, 1871, Tricholomataceae, found in plot Csörötnek 1, 3 (III), Felsőszölnök 1 (III), Kétvölgy 1 (III), Orfalu 1 (III), Öriszentpéter 1 (III), Szalafő 3 (III) and Szentgotthárd 1 (III), in stand type 1, 2, 4 and 6, on mixed (needle and leaf) litter.

Clitocybula platyphylla (Pers.) Malençon \& Bertault, Trav. Inst. Sci. Chérifien, sér. Bot. Biol. Veg. 33: 398, 1975, Marasmiaceae, found in plot Csörötnek 1 (I-III), 3 (II), 5 (III), 6 (II), Felsőszölnök 2 (III), Öriszentpéter 2, 3 (II), Szalafő 3, 6 (II), Szentgotthárd 2 (II), 3, 4 (I) and 4 (II), in stand type 1-4 and 6, on leaf and needle litter.

Clitopilus prunulus (Scop.) P. Kumm., Führ. Pilzk. (Zwickau): 96, 1871, Entolomataceae, found in plot Alsószölnök 2 (III), Szakonyfalu 1 (III) and Szalafö 2 (III), in stand type 1, 3 and 5, on mixed (needle and leaf) litter.

Collybia cirrata (Schumach.) Quél., Mém. Soc. Émul. Montbéliard, sér. 2, 5: 96, 1872, Tricholomataceae, found in plot Csörötnek 3, 5 (III), Orfalu 1 (III), Rábagyarmat (III) and Szalafó 1, 3 (III), in stand type 1-4 and 6, on mixed (needle and leaf) litter.

Collybia cookei (Bres.) J.D. Arnold, Mycologia 27(4): 413, 1935, Tricholomataceae, found in plot Alsószölnök 2 (III), Öriszentpéter 2 (III), Szalafö 1 (III) and Szentgotthárd 4 (III), in stand type 5 and 6, on mixed (needle and leaf) litter.

Collybia tuberosa (Bull.) P. Kumm., Führ. Pilzk. (Zwickau): 119, 1871, Tricholomataceae, found in plot Alsószölnök 2 (III), Öriszentpéter 3 (III), Szakonyfalu 1 (III) and Szalafö 2, 3 (III), in stand type 1 and 3-5, on mixed (needle and leaf) litter.

Conocybe enderlei var. enderlei Hauskn., Öst. Z. Pilzk. 10: 202, 2001, Bolbitiaceae, found in plot Öriszentpéter 3, 4 (III), in stand type 3 and 6, mainly on leaf, sometimes on mixed (needle and leaf) litter.

Conocybe cf. macrocephala Kühner \& Watling, Notes R. Bot. Gdn. Edinb. 38(2): 335, 1980, Bolbitiaceae, found in plot Csörötnek 1 (III), in stand type 1, on leaf litter.

Conocybe moseri Watling, Notes R. Bot. Gdn. Edinb. 38(2): 342, 1980, Bolbitiaceae, found in plot Csörötnek 1 (III), Felsőszölnök 2 (III), Öriszentpéter 3 (III) and Szalafő 1 (III), in stand type 1,3 and 6 , on leaf litter.

Conocybe ochrostriata var. ochrostriata Hauskn., Öst. Z. Pilzk. 14: 246, 2005, Bolbitiaceae, found in plot Alsószölnök 2 (III), in stand type 5, on mixed (needle and leaf) litter.

Conocybe tetrasporoides* Hauskn., Öst. Z. Pilzk. 12: 78, 2003, Bolbitiaceae, found in plot Alsószölnök 2 (III), Kétvölgy 1 (III), 2 (I, III), Öriszentpéter 3, 4 (III) and Szentgotthárd 2 (III), in stand type $1-3,5$ and 6, on mixed (needle and leaf) litter. Specimen examined: ORS-ERDO 142-51-1 (September 23, 2010). Spores 8.6-10.3 × 4.3-5.4 $\mu \mathrm{m}$, av. $9.5 \times 5.2$ $\mu \mathrm{m}, \mathrm{Qav}=1.833, \mathrm{n}=5$, amygdaloid to citriform; caulo- and cheilocystidia lecythiform; pileipellis with 15.1-17.2 $\mu \mathrm{m}$ wide, spherical elements.

Coprinellus micaceus (Bull.) Vilgalys, Hopple \& Jacq. Johnson, Taxon 50(1): 234, 2001, Psathyrellaceae, found in plot Csörötnek 1 (III), 6 (I), Kétvölgy 2 (III) and Szentgotthárd 4 (II), in stand type 1, 2, 4 and 6, on dead wood of broadleaved trees. 
Coprinopsis jonesii (Peck) Redhead, Vilgalys \& Moncalvo, Taxon 50(1): 228, 2001, Psathyrellaceae, found in plot Felsőszölnök 3 (III), in stand type 1, on leaf litter.

Cordyceps larvicola* Quél., Bull. Soc. Bot. Fr. 25: 292, 1879, Cordycipitaceae, found in plot Szakonyfalu 1 (II), in stand type 1, among mosses, on buried pupa. Specimen examined: ORS-ERDO 151-36-2b (May 29, 2010). Spores 4.4-6.3 × 1.3-1.9 $\mu \mathrm{m}$, av. $5.2 \times 1.5 \mu \mathrm{m}$, Qav $=3.452, \mathrm{n}=10$, moniliform; asci cylindrical, capitate at apex.

Coriolopsis trogii (Berk.) Domański, Mała Flora Grzybów, I Basidiomycetes (Podstawczaki), Aphyllophorales (Bezblaszkowce). (5) Corticiaceae (Kraków) 1: 230, 1974, Polyporaceae, found in plot Alsószölnök 2 (II, III) and Szalafö 2 (I), in stand type 3 and 5, on decaying wood of Populus tremula.

Cortinarius acetosus (Velen.) Melot, Docums. Mycol. 17(68): 65, 1987, Cortinariaceae, found in plot Felsöszölnök 3 (III), Szalafö 7 (III) and Szentgotthárd 4 (III), in stand type 1, 4 and 6, on leaf litter.

Cortinarius acutus (Pers.) Fr. s.1., Epicr. Syst. Mycol. (Upsaliae): 314, 1838, Cortinariaceae, found in plot Öriszentpéter 2 (III) and Szalafö 1, 3 (III), in stand type 4 and 6, on mixed (needle and leaf) litter.

Cortinarius albocyaneus* Fr., Monogr. Hymenomyc. Suec. (Upsaliae), 2(1): 62, 1863, Cortinariaceae, found in plot Öriszentpéter 1 (III), in stand type 6, on mixed (needle and leaf) litter. Specimen examined: ORS-ERDO 121-52-3 (November 3, 2010). Spores 7.5-9.4 $\times 6.3-7.2 \mu \mathrm{m}$, av. $8.4 \times 6.7 \mu \mathrm{m}$, Qav $=1.260, \mathrm{n}=16$, broadly ellipsoid, densely verrucose.

Cortinarius alboviolaceus (Pers.) Fr., Epicr. Syst. Mycol. (Upsaliae): 280, 1838, Cortinariaceae, found in plot Szakonyfalu 1 (III) and Szalafö 1 (III), in stand type 1 and 6, on mixed (needle and leaf) litter.

Cortinarius anomalus (Fr.) Fr., Epicr. Syst. Mycol. (Upsaliae): 286, 1838, Cortinariaceae, found in plot Szentgotthárd 2 (III), in stand type 3, on leaf litter.

Cortinarius anserinus (Velen.) Rob. Henry, Bull. Trimest. Soc. Mycol. Fr. 102: 54, 1986, Cortinariaceae, found in plot Felsőszölnök 3 (III), in stand type 1, on mixed (needle and leaf) litter.

Cortinarius anthracinus (Fr.) Sacc., Syll. Fung. (Abellini) 5: 941, 1887, Cortinariaceae, found in plot Apátistvánfalva (III), Csörötnek 3, 5 (III), Kétvölgy 1 (III), Orfalu 1 (III), Szakonyfalu 2 (III) and Szalafó 1, 3, 5-7 (III), in stand type 1, 2, 4 and 6, mainly on mixed (needle and leaf), sometimes on leaf litter.

Cortinarius balaustinus Fr., Epicr. Syst. Mycol. (Upsaliae): 307, 1838, Cortinariaceae, found in plot Szakonyfalu 1 (III) and Szalafó 1 (III), in stand type 1 and 6, on mixed (needle and leaf) litter.

Cortinarius balteatocumatilis Rob. Henry ex P.D. Orton, Trans. Br. Mycol. Soc. 43(2): 207, 1960, Cortinariaceae, found in plot Szakonyfalu 1 (III), in stand type 1, on leaf litter.

Cortinarius barbatus (Batsch) Melot, Docums. Mycol. 20(77): 94, 1989, Cortinariaceae, found in plot Felsöszölnök 2 (III), in stand type 1, on leaf litter.

Cortinarius bataillei J. Favre, Ergebn. Wiss. Unters. Schweiz. NatnParks, N.S. (42): 515, 1960, Cortinariaceae, found in plot Kétvölgy 1 (III), in stand type 1, on mixed (needle and leaf) litter.

Cortinarius bolaris (Pers.) Fr., Epicr. Syst. Mycol. (Upsaliae): 282, 1838, Cortinariaceae, found in plot Orfalu 1 (I, III) and Szalafö 1 (III), in stand type 6, on mixed (needle and leaf) litter.

Cortinarius cagei Melot, Docums. Mycol. 20(80): 58, 1990, Cortinariaceae, found in plot Felsőszölnök 3 (III), Kétvölgy 1 (III), Rábagyarmat (III), Szakonyfalu 1, 2 (III), Szalafő 1, 2, 7 (III) and Szentgotthárd 1 (III), in stand type 1-4 and 6, on mixed (needle and leaf) litter.

Cortinarius callisteus (Fr.) Fr., Epicr. Syst. Mycol. (Upsaliae): 281, 1838, Cortinariaceae, found in plot Apátistvánfalva (III) and Szalafö 4 (III), in stand type 6, on mixed (needle and leaf) litter. 
Cortinarius calochrous (Pers.) Gray, Nat. Arr. Brit. Pl. (London) 1: 629, 1821, Cortinariaceae, found in plot Felsőszölnök 3 (III) and Szentgotthárd 4 (III), in stand type 1 and 6, on leaf litter.

Cortinarius camphoratus (Fr) Fr., Epicr. Syst. Mycol. (Upsaliae): 280, 1838, Cortinariaceae, found in plot Szalafö 3 (III), in stand type 4, on mixed (needle and leaf) litter.

Cortinarius caperatus (Pers.) Fr., Epicr. Syst. Mycol. (Upsaliae): 256, 1838, Cortinariaceae, found in plot Szalafö 3 (III), in stand type 4, on mixed (needle and leaf) litter.

Cortinarius casimiri (Velen.) Huijsman, Fungus (Wageningen) 25: 20, 1955, Cortinariaceae, found in plot Alsószölnök 2 (III), Apátistvánfalva (III), Csörötnek 1, 3 (III), Felsőszölnök 2 (III), Magyarlak (III), Orfalu 1 (III), Szakonyfalu 1 (III), Szalafö 1, 2, 6, 7 (III) and Szentgotthárd 2 (III), in stand type 1-6, mainly on mixed (needle and leaf), sometimes on leaf litter.

Cortinarius cinnabarinus Fr., Epicr. Syst. Mycol. (Upsaliae): 287, 1838, Cortinariaceae, found in plot Felsőszölnök 3 (III) and Szentgotthárd 2 (III), in stand type 1 and 3, on leaf litter.

Cortinarius cinnamomeus (L.) Gray, Nat. Arr. Brit. Pl. (London) 1: 630, 1821, Cortinariaceae, found in plot Alsószölnök 2 (III), in stand type 5, on mixed (needle and leaf) litter.

Cortinarius citrinus (J.E. Lange) P.D. Orton, Trans. Br. Mycol. Soc. 43(2): 208, 1960, Cortinariaceae, found in plot Szentgotthárd 4 (III), in stand type 6, on mixed (needle and leaf) litter.

Cortinarius comptulus* M.M. Moser, Nova Hedwigia, 14(2-4): 514, 1968, Cortinariaceae, found in plot Alsószölnök 1 (III), in stand type 6, on mixed (needle and leaf) litter. Specimen examined: ORS-ERDO 108-22-1b (September 23, 2010). Spores 5.6-6.9 × 4.7-5.9 $\mu \mathrm{m}$, av. $6.3 \times 5.1 \mu \mathrm{m}, \mathrm{Qav}=1.238, \mathrm{n}=16$, subglobose to broadly ellipsoid, densely verrucose, weakly dextrinoid.

Cortinarius croceocaeruleus (Pers.) Fr., Hymenomyc. Eur. (Upsaliae): 352, 1874, Cortinariaceae, found in plot Szentgotthárd 4 (III), in stand type 6, on mixed (needle and leaf) litter.

Cortinarius croceus (Schaeff.) Gray, Nat. Arr. Brit. Pl. (London) 1: 630, 1821, Cortinariaceae, found in plot Kétvölgy 1 (III) and Szalafó 1 (III), in stand type 1 and 6, on mixed (needle and leaf) litter.

Cortinarius decipiens (Pers.) Fr. s.1., Epicr. Syst. Mycol. (Upsaliae): 312, 1838, Cortinariaceae, found in plot Alsószölnök 1 (III), Apátistvánfalva (III), Csörötnek 1, 4, 5, 6 (III), Felsőszölnök 2, 3 (III), Kétvölgy 1, 2 (III), Orfalu 1, 2 (III), Öriszentpéter 2 (III), Szakonyfalu 1, 2 (III), Szalafö 1-7 (III) and Szentgotthárd 2, 4 (III), in stand type 1-4 and 6 , mainly on leaf, sometimes on mixed (needle and leaf) litter.

Cortinarius delibutus Fr., Epicr. Syst. Mycol. (Upsaliae): 276, 1838, Cortinariaceae, found in plot Orfalu 1 (III), in stand type 6, on mixed (needle and leaf) litter.

Cortinarius depressus Fr., Epicr. Syst. Mycol. (Upsaliae): 314, 1838, Cortinariaceae, found in plot Kétvölgy 1 (III), in stand type 1, on leaf litter.

Cortinarius diasemospermus var. diasemospermus Lamoure, Trav. Sci. Parc. Natl. Vanoise 9: 99, 1978, Cortinariaceae, found in plot Apátistvánfalva (III), Szakonyfalu 1, 2 (III), Szalafö 1, 3, 5 (III) and Szentgotthárd 4 (III), in stand type 1, 2, 4 and 6, mainly on mixed (needle and leaf), sometimes on leaf litter.

Cortinarius diasemospermus var. leptospermus H. Lindstr., Cortinarius. Flora photographica, 4: 20, 1998, Cortinariaceae, found in plot Csörötnek 5 (III), in stand type 1, on leaf litter.

Cortinarius duracinus Fr. s.1., Epicr. Syst. Mycol. (Upsaliae): 304, 1838, Cortinariaceae, found in plot Szalafö 3 (III) and Szentgotthárd 2 (III), in stand type 3 and 4, mainly on leaf, sometimes on mixed (needle and leaf) litter.

Cortinarius elatior Fr., Epicr. Syst. Mycol. (Upsaliae): 274, 1838, Cortinariaceae, found in plot Alsószölnök 1 (III), Apátistvánfalva (III), Csörötnek 4, 5 (III), Felsőszölnök 1-3 (III), Kétvölgy 1 (III), Szakonyfalu 2 (III), Szalafö 3, 5, 7 (III) and Szentgotthárd 4 (III), in stand type 1-4 and 6, mainly on leaf, sometimes on mixed (needle and leaf) litter. 
Cortinarius emollitoides Bidaud, Moënne-Locc. \& Reumaux, Atlas des Cortinaires (Meyzieu) 10: 491, 2000, Cortinariaceae, found in plot Csörötnek 5 (III) and Szalafö 1, 3 (III), in stand type 1, 4 and 6, mainly on mixed (needle and leaf), sometimes on leaf litter.

Cortinarius emunctus Fr., Epicr. Syst. Mycol. (Upsaliae): 275, 1838, Cortinariaceae, found in plot Apátistvánfalva (III), Szakonyfalu 1 (III) and Szalafö 2, 4 (III), in stand type 1, 3 and 6, mainly on mixed (needle and leaf), sometimes on leaf litter.

Cortinarius erubescens M.M. Moser, Nova Hedwigia, 14(2-4): 515, 1968, Cortinariaceae, found in plot Csörötnek 6 (III), Szalafö 1 (III) and Szentgotthárd 2 (III), in stand type 3, 4 and 6, mainly on leaf, sometimes on mixed (needle and leaf) litter.

Cortinarius flexipes var. flabellus (Fr.) H. Lindstr. \& Melot, Cortinarius. Flora photographica, 4: 15, 1998, Cortinariaceae, found in plot Csörötnek 3, 5, 6 (III), Felsőszölnök 3 (III), Kétvölgy 1 (III), Rábagyarmat (III), Szalafö 3, 6 (III) and Szentgotthárd 2 (III), in stand type 1-4, mainly on leaf, sometimes on mixed (needle and leaf) litter.

Cortinarius flexipes var. flexipes (Pers.) Fr., Epicr. Syst. Mycol. (Upsaliae): 300, 1838, Cortinariaceae, found in plot Apátistvánfalva (III), Csörötnek 3, 5 (III), Felsőszölnök 3 (III), Kétvölgy 1 (III), Orfalu 1 (III), Szakonyfalu 1, 2 (III), Szalafö 1-4, 7 (III) and Szentgotthárd 4 (III), in stand type 1-4 and 6, mainly on mixed (needle and leaf), sometimes on leaf litter.

Cortinarius flexipes var. inolens H. Lindstr., Cortinarius. Flora photographica, 4: 20, 1998, Cortinariaceae, found in plot Szakonyfalu 2 (III), in stand type 2, on mixed (needle and leaf) litter.

Cortinarius fulvescens Fr. s.1., Epicr. Syst. Mycol. (Upsaliae): 311, 1838, Cortinariaceae, found in plot Szalafö 1 (III), in stand type 6, on mixed (needle and leaf) litter.

Cortinarius glaucopus (Schaeff.) Gray, Nat. Arr. Brit. Pl. (London) 1: 629, 1821, Cortinariaceae, found in plot Apátistvánfalva (III) and Szentgotthárd 2 (III), in stand type 3 and 6, mainly on leaf, sometimes on mixed (needle and leaf) litter.

Cortinarius herpeticus Fr., Epicr. Syst. Mycol. (Upsaliae): 268, 1838, Cortinariaceae, found in plot Szalafó 2 (III), in stand type 3, on leaf litter.

Cortinarius hinnuleus Fr. s.1., Epicr. Syst. Mycol. (Upsaliae): 296, 1838, Cortinariaceae, found in plot Szalafö 2, 3, 7 (III), in stand type 3 and 4, on leaf litter.

Cortinarius infractus (Pers.) Fr. s.l., Epicr. Syst. Mycol. (Upsaliae): 261, 1838, Cortinariaceae, found in plot Apátistvánfalva (III), Felsőszölnök 3 (III), Öriszentpéter 3 (III), Szalafö 2-4 (III) and Szentgotthárd 4 (III), in stand type 1, 3, 4 and 6, mainly on mixed (needle and leaf), sometimes on leaf litter.

Cortinarius largus Fr., Epicr. Syst. Mycol. (Upsaliae): 259, 1838, Cortinariaceae, found in plot Apátistvánfalva (III), Kétvölgy 1 (III), Szalafö 2 (I) and Szentgotthárd 2 (III), in stand type 1,3 and 6, mainly on leaf, sometimes on mixed (needle and leaf) litter.

Cortinarius lebretonii Quél., Bull. Soc. Amis Sci. Nat. Rouen, sér. 2, 15: 164, 1880, Cortinariaceae, found in plot Szalafö 3 (III), in stand type 4, on mixed (needle and leaf) litter.

Cortinarius lepidopus* Cooke, Grevillea 16(78): 43, 1887, Cortinariaceae, found in plot Szalafö 1, 2 (III), in stand type 3 and 6, mainly on leaf, sometimes on mixed (needle and leaf) litter. Specimen examined: ORS-ERDO 99-11-4b (September 22, 2010). Spores 6.3-8.1 × 5.6-6.3 $\mu \mathrm{m}$, av. $7.2 \times 5.9 \mu \mathrm{m}, \mathrm{Qav}=1.221, \mathrm{n}=20$, subglobose to broadly ellipsoid, distinctly verrucose.

Cortinarius luhmannii Münzmay, Saar \& B. Oertel, Journal des JEC 7(6): 31, 2004, Cortinariaceae, found in plot Csörötnek 3 (III), Felsőszölnök 1 (III) and Szentgotthárd 4 (III), in stand type 1, 2 and 6, on mixed (needle and leaf) litter.

Cortinarius melleopallens (Fr.) Britzelm., Bot. Zbl. 51(2-3): 38, 1892, Cortinariaceae, found in plot Szalafó 1, 7 (III), in stand type 4 and 6, mainly on leaf, sometimes on mixed (needle and leaf) litter. 
Cortinarius nemorensis s. Saar (Fr.) J.E. Lange, Fl. Agaric. Danic. 5: 3, 1940, Cortinariaceae, found in plot Szakonyfalu 1 (III) and Szalafö 2 (III), in stand type 1 and 3, mainly on leaf, sometimes on mixed (needle and leaf) litter.

Cortinarius obtusus (Fr.) Fr., Epicr. Syst. Mycol. (Upsaliae): 313, 1838, Cortinariaceae, found in plot Szalafö 3 (III), in stand type 4, on mixed (needle and leaf) litter.

Cortinarius olidoamethysteus Rob. Henry \& Ramm, Bull. Trimest. Féd. Mycol. Dauphiné-Savoie 29(115): 11, 1989, Cortinariaceae, found in plot Alsószölnök 1 (III) and Felsőszölnök 3 (III), in stand type 1 and 6, mainly on mixed (needle and leaf), sometimes on needle litter.

Cortinarius olivaceofuscus Kühner, Bull. Mens. Soc. Linn. Lyon, 24: 39, 1955, Cortinariaceae, found in plot Csörötnek 3 (III) and Szalafö 6, 7 (III), in stand type 2 and 4, mainly on leaf, sometimes on mixed (needle and leaf) litter.

Cortinarius orellanus Fr., Epicr. Syst. Mycol. (Upsaliae): 288, 1838, Cortinariaceae, found in plot Alsószölnök 1 (III) and Szakonyfalu 1 (III), in stand type 1 and 6, on mixed (needle and leaf) litter.

Cortinarius praestigiosus (Fr.) M.M. Moser, Schweiz. Z. Pilzk. 43: 131, 1965, Cortinariaceae, found in plot Csörötnek 5 (III) and Szentgotthárd 2 (III), in stand type 1 and 3, on leaf litter.

Cortinarius psammocephalus (Bull.) Fr., Epicr. Syst. Mycol. (Upsaliae): 301, 1838, Cortinariaceae, found in plot Csörötnek 6 (III), Felsőszölnök 3 (III) and Szalafö 3, 7 (III), in stand type 1 and 4, mainly on leaf, sometimes on mixed (needle and leaf) litter.

Cortinarius purpurascens Fr., Epicr. Syst. Mycol. (Upsaliae): 265, 1838, Cortinariaceae, found in plot Alsószölnök 1 (III), in stand type 6, on mixed (needle and leaf) litter.

Cortinarius raphanoides (Pers.) Fr., Epicr. Syst. Mycol. (Upsaliae): 290, 1838, Cortinariaceae, found in plot Szalafö 1 (III), in stand type 6, on mixed (needle and leaf) litter.

Cortinarius renidens Fr., Epicr. Syst. Mycol. (Upsaliae): 308, 1838, Cortinariaceae, found in plot Apátistvánfalva (I, III) and Kétvölgy 1 (III), in stand type 1 and 6, mainly on mixed (needle and leaf), sometimes on leaf litter.

Cortinarius rigidipes* M.M. Moser, Nova Hedwigia, 14(2-4): 516, 1968, Cortinariaceae, found in plot Apátistvánfalva (III), Csörötnek 4 (III), Kétvölgy 2 (III), Öriszentpéter 3 (III), Szalafö 3, 7 (III) and Szentgotthárd 2 (III), in stand type 2-4 and 6, mainly on leaf, sometimes on mixed (needle and leaf) litter. Specimen examined: ORS-ERDO 100-12-1b (October 20, 2010). Spores 8.1-9.7 × 4.7-5.6 $\mu \mathrm{m}$, av. $9.1 \times 5.3 \mu \mathrm{m}$, Qav $=1.737, \mathrm{n}=16$, amygdaloid, strongly verrucose, strongly dextrinoid.

Cortinarius safranopes Rob. Henry, Bull. Trimest. Soc. Mycol. Fr. 54: 95, 1938, Cortinariaceae, found in plot Rábagyarmat (III) and Szalafó 2 (III), in stand type 3, on leaf litter.

Cortinarius scaurotraganoides Rob. Henry ex Rob. Henry, Bull. Soc. Mycol. Fr. 102: 78, 1986, Cortinariaceae, found in plot Orfalu 2 (III), in stand type 4, on leaf litter.

Cortinarius semisanguineus (Fr.) Gillet, Hyménomycètes (Alençon): 484, 1876, Cortinariaceae, found in plot Szalafö 1 (III), in stand type 6, on mixed (needle and leaf) litter.

Cortinarius sp.01, Cortinariaceae, found in plot Szalafó 2 (III), in stand type 3, on leaf litter. Specimen examined: ORS-ERDO 99-36-1b (September 22, 2010). Spores 7.2-8.3 × 5.6-6.3 $\mu \mathrm{m}$, av. $7.6 \times 6.1 \mu \mathrm{m}, \mathrm{Qav}=1.259, \mathrm{n}=15$, broadly ellipsoid to ovoid, densely but weakly verrucose, finely dextrinoid.

Cortinarius sp.02, Cortinariaceae, found in plot Szakonyfalu 1 (III), in stand type 1, on mixed (needle and leaf) litter. Specimen examined: ORS-ERDO 151-32-1b (September 24, 2010). Spores 6.3-7.5 × 4.1-4.7 $\mu \mathrm{m}$, av. $7.0 \times 4.3 \mu \mathrm{m}, \mathrm{Qav}=1.617, \mathrm{n}=20$, ellipsoid, finely verrucose, weakly dextrinoid.

Cortinarius sp.03, Cortinariaceae, found in plot Szalafö 1 (III), in stand type 6, on mixed (needle and leaf) litter. Specimen examined: ORS-ERDO 98-16-1b (September 21, 2010). Spores 8.1-10.6 $\times 5.0-6.3 \mu \mathrm{m}$, av. $9.5 \times 5.6 \mu \mathrm{m}$, Qav $=1.686, \mathrm{n}=15$, ellipsoid-amygdaloidobovoid, strongly and densely verrucose, moderately to fairly strongly dextrinoid. 
Cortinarius sp.04, Cortinariaceae, found in plot Csörötnek 4 (II, III), in stand type 3, on leaf litter. Specimen examined: ORS-ERDO 119-24-1 (October 24, 2010). Spores 6.3-7.5 × 3.8-5.6 $\mu \mathrm{m}$, av. $6.7 \times 4.6 \mu \mathrm{m}, \mathrm{Qav}=1.455, \mathrm{n}=15$, ellipsoid, weakly verrucose, indextrinoid.

Cortinarius sp.05, Cortinariaceae, found in plot Szakonyfalu 1 (III), in stand type 1, on mixed (needle and leaf) litter. Specimen examined: ORS-ERDO 151-53-1b (September 24, 2010). Spores 5.9-6.9 $\times 4.4-5.0 \mu \mathrm{m}$, av. $6.5 \times 4.6 \mu \mathrm{m}, \mathrm{Qav}=1.412, \mathrm{n}=20$, broadly ellipsoid to ellipsoid, finely verrucose, weakly dextrinoid.

Cortinarius sp.06, Cortinariaceae, found in plot Öriszentpéter 3 (III), in stand type 3, on leaf litter. Specimen examined: ORS-ERDO 125-15-5b (September 19, 2010). Spores 6.9-8.8 × 4.7$5.6 \mu \mathrm{m}$, av. $7.6 \times 5.1 \mu \mathrm{m}, \mathrm{Qav}=1.500, \mathrm{n}=30$, subglobose-obvoid-dacryoid, strongly verrucose, moderately to strongly dextrinoid.

Cortinarius sp.07, Cortinariaceae, found in plot Felsőszölnök 3 (III) and Szalafö 3 (III), in stand type 1 and 4, mainly on leaf, sometimes on mixed (needle and leaf) litter. Specimen examined: ORS-ERDO 149-42-1b (October 16, 2010). Spores 7.8-9.1 × 5.3-6.3 $\mu \mathrm{m}$, av. $8.6 \times 5.6 \mu \mathrm{m}, \mathrm{Qav}=1.530, \mathrm{n}=15$, dacryoid-obovoid-ellipsoid, distinctly and coarsely verrucose, moderately dextrinoid.

Cortinarius sp.08, Cortinariaceae, found in plot Csörötnek 5 (III), Rábagyarmat (III) and Szakonyfalu 1 (III), in stand type 1 and 3, mainly on leaf, sometimes on mixed (needle and leaf) litter. Specimen examined: ORS-ERDO 137-22-1 (October 10, 2010). Spores 6.3-7.5 $\times 4.4-5.0 \mu \mathrm{m}$, av. $7.0 \times 4.8 \mu \mathrm{m}, \mathrm{Qav}=1.466, \mathrm{n}=20$, ellipsoid-ovoid, distinctly verrucose (more at apex), moderately to fairly strongly dextrinoid.

Cortinarius sp.09, Cortinariaceae, found in plot Szakonyfalu 1 (III), in stand type 1, on mixed (needle and leaf) litter. Specimen examined: ORS-ERDO 151-43-1b (September 24, 2010). Spores 6.3-8.1 $\times 4.1-4.7 \mu \mathrm{m}$, av. 7.2 $\times 4.4 \mu \mathrm{m}$, Qav $=1.650, \mathrm{n}=25$, plum-shaped, fusoid to ellipsoid, verrucose, dextrinoid.

Cortinarius sp.10, Cortinariaceae, found in plot Szalafó 2 (III), in stand type 3, on leaf litter. Specimen examined: ORS-ERDO 99-11-2b (September 22, 2010). Spores 6.3-7.5 × 4.4-5.0 $\mu \mathrm{m}$, av. $6.9 \times 4.7 \mu \mathrm{m}, \mathrm{Qav}=1.472, \mathrm{n}=12$, ellipsoid to broadly ellipsoid, verrucose, moderately to fairly strongly dextrinoid.

Cortinarius sp.11, Cortinariaceae, found in plot Kétvölgy 1 (III), in stand type 1, on leaf litter. Specimen examined: ORS-ERDO 107-65-1b (October 17, 2010). Spores 8.1-10.0 × 5.6-7.2 $\mu \mathrm{m}$, av. $9.0 \times 6.0 \mu \mathrm{m}, \mathrm{Qav}=1.505, \mathrm{n}=15$, ellipsoid to broadly ellipsoid, moderately to fairly strongly verrucose, weakly to moderately dextrinoid.

Cortinarius sp.12, Cortinariaceae, found in plot Csörötnek 4 (III), in stand type 3, on leaf litter. Specimen examined: ORS-ERDO 119-56-1 (October 24, 2010). Spores 6.9-7.8 × 5.0-5.6 $\mu \mathrm{m}$, av. $7.3 \times 5.3 \mu \mathrm{m}, \mathrm{Qav}=1.374, \mathrm{n}=15$, broadly ellipsoid to obovoidly subglobose, densely or distinctly verrucose, strongly dextrinoid.

Cortinarius sp.13, Cortinariaceae, found in plot Öriszentpéter 3 (III), in stand type 3, on leaf litter. Specimen examined: ORS-ERDO 125-25-1b (September 19, 2010). Spores 8.4-9.4 × 5.0 $5.6 \mu \mathrm{m}$, av. $9.0 \times 5.3 \mu \mathrm{m}, \mathrm{Qav}=1.693, \mathrm{n}=15$, ellispoid-obovoid, distinctly and fairly strongly verrucose, moderately to fairly strongly dextrinoid.

Cortinarius sp.14, Cortinariaceae, found in plot Szakonyfalu 1 (III) and Szalafö 2, 3, 6 (III), in stand type 1, 3 and 4, mainly on leaf, sometimes on mixed (needle and leaf) litter. Specimen examined: ORS-ERDO 151-11-5b (September 24, 2010). Spores 6.9-8.4 × 4.3-5.0 $\mu \mathrm{m}$, av. $7.2 \times 4.6 \mu \mathrm{m}, \mathrm{Qav}=1.557, \mathrm{n}=20$, ellipsoid, verrucose, strongly dextrinoid.

Cortinarius sp.15, Cortinariaceae, found in plot Alsószölnök 2 (III), Apátistvánfalva (III), Csörötnek 1, 5, 6 (III), Felsöszölnök 2 (III), Orfalu 1 (III), Szakonyfalu 1 (III) and Szalafö $1-3,6,7$ (III), in stand type 1 and 3-6, mainly on leaf, sometimes on mixed (needle and leaf) litter. Specimen examined: ORS-ERDO 136-31-1 (October 9, 2010). Spores 5.9-7.6 $\times$ 4.1-5.0 $\mu \mathrm{m}$, av. $7.0 \times 4.5 \mu \mathrm{m}, \mathrm{Qav}=1.560, \mathrm{n}=21$, ellipsoid-obovoid-ovoid, moderately verrucose, moderately to fairly strongly dextrinoid. 
Cortinarius sp.16, Cortinariaceae, found in plot Apátistvánfalva (III), in stand type 6, on mixed (needle and leaf) litter. Specimen examined: ORS-ERDO 156-52-3b (October 19, 2010). Spores 7.2-8.8 $\times$ 4.9-5.6 $\mu \mathrm{m}$, av. $7.9 \times 5.1 \mu \mathrm{m}$, $\mathrm{Qav}=1.558, \mathrm{n}=20$, ellipsoid, moderatley verrucose, moderately dextrinoid.

Cortinarius sp.17, Cortinariaceae, found in plot Szalafö 3 (III), in stand type 4, on mixed (needle and leaf) litter. Specimen examined: ORS-ERDO 100-14-1b (October 20, 2010). Spores 5.8-7.8 $\times 4.4-5.3 \mu \mathrm{m}$, av. $6.6 \times 4.9 \mu \mathrm{m}, \mathrm{Qav}=1.367, \mathrm{n}=30$, subglobose to broadly ellipsoid, strongly verrucose, spiny.

Cortinarius sp.18, Cortinariaceae, found in plot Öriszentpéter 3 (III), in stand type 3, on leaf litter. Specimen examined: ORS-ERDO 125-12-5b (September 19, 2010). Spores 7.2-8.4 × 4.9$5.6 \mu \mathrm{m}$, av. $7.6 \times 5.2 \mu \mathrm{m}$, Qav $=1.446, \mathrm{n}=15$, ellipsoid-ovoid, strongly verrucose (more at apex), moderately to fairly strongly dextrinoid.

Cortinarius sp.19, Cortinariaceae, found in plot Szalafó 1 (III), in stand type 6, on mixed (needle and leaf) litter. Specimen examined: ORS-ERDO 98-35-2b (September 21, 2010). Spores 5.0-5.9 $\times 3.8-4.4 \mu \mathrm{m}$, av. $5.5 \times 4.2 \mu \mathrm{m}$, $\mathrm{Qav}=1.301, \mathrm{n}=15$, broadly ellipsoid to ovoid, weakly verrucose, indextrinoid.

Cortinarius sp.20, Cortinariaceae, found in plot Felsőszölnök 3 (III), in stand type 1, on leaf litter. Specimen examined: ORS-ERDO 149-24-2b (October 16, 2010). Spores 8.1-9.1 × 5.0-5.5 $\mu \mathrm{m}$, av. $8.6 \times 5.1 \mu \mathrm{m}, \mathrm{Qav}=1.676, \mathrm{n}=13$, ellispoid-obovoid (dacryoid), verrucose, fairly strongly dextrinoid.

Cortinarius sp.21, Cortinariaceae, found in plot Szalafó 2 (III), in stand type 3, on leaf litter. Specimen examined: ORS-ERDO 99-24-1b (September 22, 2010). Spores 7.2-8.8 × 4.5-5.0 $\mu \mathrm{m}$, av. $7.9 \times 4.9 \mu \mathrm{m}, \mathrm{Qav}=1.620, \mathrm{n}=20$, ellipsoid to obtusely ellipsoid, densely, distinctly verrucose, fairly strongly dextrinoid.

Cortinarius sp.22, Cortinariaceae, found in plot Szakonyfalu 1 (III) and Szalafö 2 (III), in stand type 1 and 3, mainly on mixed (needle and leaf), sometimes on leaf litter. Specimen examined: ORS-ERDO 99-11-3b (September 22, 2010). Spores 6.6-8.1 × 4.4-5.0 $\mu \mathrm{m}$, av. $7.5 \times 4.7 \mu \mathrm{m}, \mathrm{Qav}=1.604, \mathrm{n}=15$, ellipsoid, to obovoidly ellipsoid, densely but weakly verrucose, strongly to fairly strongly dextrinoid.

Cortinarius sp.23, Cortinariaceae, found in plot Öriszentpéter 2 (III), in stand type 6, on mixed (needle and leaf) litter. Specimen examined: ORS-ERDO 124-43-2b (September 20, 2010). Spores 8.1-10.0 × 5.5-6.3 $\mu \mathrm{m}$, av. $9.3 \times 5.9 \mu \mathrm{m}, \mathrm{Qav}=1.578, \mathrm{n}=15$, ellipsoid-obovoidovoid, densely and distinctly verrucose, weakly to fairly weakly dextrinoid (more at apex).

Cortinarius sp.24, Cortinariaceae, found in plot Szalafó 2 (III), in stand type 3, on leaf litter. Specimen examined: ORS-ERDO 99-15-1b (September 22, 2010). Spores 7.8-8.8 × 4.5-5.3 $\mu \mathrm{m}$, av. $8.3 \times 5.0 \mu \mathrm{m}, \mathrm{Qav}=1.664, \mathrm{n}=10$, amygdaloid to ellipsoid, very strongly (spiny) verrucose, more distinctly at apex, fairly strongly to strongly dextrinoid.

Cortinarius subbalaustinus Rob. Henry, Docums. Mycol. 16(61): 28, 1985, Cortinariaceae, found in plot Orfalu 1 (III), in stand type 6, on mixed (needle and leaf) litter.

Cortinarius subporphyropus Pilát, Česká Mykol. 8(1): 6, 1954, Cortinariaceae, found in plot Csörötnek 3, 5 (III), Rábagyarmat (III) and Szalafö 3, 5 (III), in stand type 1-4, mainly on leaf, sometimes on mixed (needle and leaf) litter.

Cortinarius subpurpurascens (Batsch) Fr., Epicr. Syst. Mycol. (Upsaliae): 265, 1838, Cortinariaceae, found in plot Szalafo' 2 (III), in stand type 3, on leaf litter.

Cortinarius tabularis* (Fr.) Fr., Epicr. Syst. Mycol. (Upsaliae): 284, 1838, Cortinariaceae, found in plot Csörötnek 4 (III), Öriszentpéter 1 (III), Szakonyfalu 1 (III) and Szalafö 1, 4, 7 (III), in stand type 1, 3, 4 and 6, mainly on mixed (needle and leaf), sometimes on leaf litter. Specimen examined: ORS-ERDO 102-66-2 (October 20, 2010). Spores 7.5-8.8 × 5.6-6.6 $\mu \mathrm{m}$, av. $8.0 \times 5.9 \mu \mathrm{m}, \mathrm{Qav}=1.353, \mathrm{n}=10$, broadly ellipsoid to subglobose, moderately to distinctly verrucose, fairly weakly to moderately dextrinoid. 
Cortinarius talus Fr., Epicr. Syst. Mycol. (Upsaliae): 263, 1838, Cortinariaceae, found in plot Kétvölgy 1 (III) and Szalafö 1, 2 (III), in stand type 1, 3 and 6, mainly on mixed (needle and leaf), sometimes on leaf litter.

Cortinarius terpsichores Melot, Docums. Mycol. 20(77): 96, 1989, Cortinariaceae, found in plot Szakonyfalu 1 (III), in stand type 1, on leaf litter.

Cortinarius torvus (Fr.) Fr., Epicr. Syst. Mycol. (Upsaliae): 293, 1838, Cortinariaceae, found in plot Csörötnek 4 (III), Felsőszölnök 1, 3 (III), Kétvölgy 1 (III), Szakonyfalu 1 (III) and Szalafö 2, 3 (III), in stand type 1, 3 and 4, mainly on leaf, sometimes on mixed (needle and leaf) litter.

Cortinarius trivialis J.E. Lange s.1., Fl. Agaric. Danic. 5: 3, 1940, Cortinariaceae, found in plot Csörötnek 4 (III), Felsőszölnök 1, 3 (III), Kétvölgy 1 (III), Szakonyfalu 1 (III) and Szalafö 2, 3, 5 (III), in stand type 1, 3 and 4, mainly on mixed (needle and leaf), sometimes on leaf litter.

Cortinarius turgidus Fr., Epicr. Syst. Mycol. (Upsaliae): 278, 1838, Cortinariaceae, found in plot Felsőszölnök 3 (III), in stand type 1, on leaf litter.

Cortinarius umbonatoides* Moënne-Locc. \& Reumaux, Atlas des Cortinaires (Meyzieu) 17: 1178, 2008, Cortinariaceae, found in plot Szakonyfalu 1 (II) and Szalafó 1, 2 (II), in stand type 1, 3 and 6, mainly on mixed (needle and leaf), sometimes on leaf litter. Specimen examined: ORS-ERDO 99-65-1b (May 26, 2010). Spores 8.1-10.0 × 4.4-5.6 $\mu \mathrm{m}$, av. $9.0 \times 5.0 \mu \mathrm{m}$, Qav $=1.809, \mathrm{n}=20$, amygdaloid, moderately verrucose, moderately dextrinoid.

Cortinarius urbicus (Fr.) Fr., Epicr. Syst. Mycol. (Upsaliae): 293, 1838, Cortinariaceae, found in plot Szalafö 3 (III), in stand type 4, on leaf litter.

Cortinarius valgus Fr., Epicr. Syst. Mycol. (Upsaliae): 290, 1838, Cortinariaceae, found in plot Orfalu 1 (III), in stand type 6, on mixed (needle and leaf) litter.

Cortinarius variecolor (Pers.) Fr., Epicr. Syst. Mycol. (Upsaliae): 259 1838, Cortinariaceae, found in plot Szentgotthárd 2 (III), in stand type 3, on leaf litter.

Cortinarius venetus (Fr.) Fr., Epicr. Syst. Mycol. (Upsaliae): 291, 1838, Cortinariaceae, found in plot Csörötnek 1 (III) and Szalafö 2-4, 7 (III), in stand type 1, 3, 4 and 6, mainly on leaf, sometimes on mixed (needle and leaf) litter.

Cortinarius veregregius* Rob. Henry, Bull. Trimest. Soc. Mycol. Fr. 54: 104, 1938, Cortinariaceae, found in plot Orfalu 1 (III) and Szakonyfalu 2 (III), in stand type 2 and 6, on mixed (needle and leaf) litter. Specimen examined: ORS-ERDO 152-22-1b (October 19, 2010). Spores 6.9-8.1 × 4.4-5.3 $\mu \mathrm{m}$, av. $7.4 \times 4.9 \mu \mathrm{m}, \mathrm{Qav}=1.519, \mathrm{n}=10$, ellipsoid, finely verrucose, weakly to moderately dextrinoid.

Cortinarius vibratilis (Fr.) Fr., Epicr. Syst. Mycol. (Upsaliae): 277, 1838, Cortinariaceae, found in plot Szalafó 1, 2 (III), in stand type 3 and 6, mainly on mixed (needle and leaf), sometimes on leaf litter.

Cortinarius violaceus (L.) Gray, Nat. Arr. Brit. Pl. (London) 1: 628, 1821, Cortinariaceae, found in plot Orfalu 1 (I, III), Szakonyfalu 1 (III) and Szalafó 4 (III), in stand type 1 and 6, on mixed (needle and leaf) litter.

Cortinarius vulpinus (Velen.) Rob. Henry, Bull. Trimest. Soc. Mycol. Fr. 62: 207, 1947, Cortinariaceae, found in plot Felsőszölnök 2 (III), in stand type 1, on leaf litter.

Cortinarius xanthocephalus P.D. Orton, Trans. Br. Mycol. Soc. 43(2): 214, 1960, Cortinariaceae, found in plot Öriszentpéter 1 (III), in stand type 6, on mixed (needle and leaf) litter.

Cortinarius xanthophyllus (Cooke) Rob. Henry, Revue Mycol. (Paris) 8 (suppl.): 30, 1943, Cortinariaceae, found in plot Szalafö 2 (III), in stand type 3, on leaf litter.

Craterellus cornucopioides (L.) Pers., Mycol. Eur. (Erlanga) 2: 5, 1825, Cantharellaceae, found in plot Alsószölnök 1 (III), Csörötnek 1, 3, 5, 6 (III), Orfalu 2 (III), Szalafö 1, 5 (III) and Szentgotthárd 2 (III), in stand type 1-4 and 6, mainly on leaf, sometimes on mixed (needle and leaf) litter. 
Craterellus lutescens (Pers.) Fr., Epicr. Syst. Mycol. (Upsaliae): 532, 1838, Cantharellaceae, found in plot Alsószölnök 1 (III), Apátistvánfalva (III), Orfalu 2 (III), Öriszentpéter 2 (III) and Szalafö 1, 4 (III), in stand type 4 and 6, on mixed (needle and leaf) litter.

Craterellus tubaeformis (Fr.) Quél., Fl. Mycol. France (Paris): 36, 1888, Cantharellaceae, found in plot Apátistvánfalva (III), Kétvölgy 1 (III) and Szakonyfalu 1 (III), in stand type 1 and 6, mainly on mixed (needle and leaf), sometimes on leaf litter.

Crepidotus applanatus (Pers.) P. Kumm., Führ. Pilzk. (Zwickau): 74, 1871, Crepidotaceae, found in plot Öriszentpéter 3 (II), in stand type 3, on decaying wood of Fagus sylvatica.

Crepidotus calolepis (Fr.) P. Karst., Bidr. Känn. Finl. Nat. Folk 32: 414, 1879, Crepidotaceae, found in plot Alsószölnök 2 (III), in stand type 5, on decaying wood of Populus tremula.

Crepidotus cesatii (Rabenh.) Sacc., Michelia 1(1): 2, 1877, Crepidotaceae, found in plot Apátistvánfalva (III), Csörötnek 5 (III), Orfalu 1 (III), Öriszentpéter 1, 2, 4 (III), Szakonyfalu 2 (II, III) and Szalafö 4 (III), in stand type 1, 2 and 6, on decaying wood of Fagus sylvatica and Carpinus betulus.

Crepidotus epibryus (Fr.) Quél., Mém. Soc. Émul. Montbéliard, sér. 2, 5: 138, 1872, Crepidotaceae, found in plot Szalafó 1, 5 (III), in stand type 4 and 6, on dead wood of broadleaved trees.

Crepidotus luteolus Sacc., Syll. Fung. (Abellini) 5: 888, 1887, Crepidotaceae, found in plot Szalafó 5 (III) and Szentgotthárd 2 (III), in stand type 3 and 4, on dead wood of broadleaved trees.

Crepidotus mollis (Schaeff.) Staude, Schwämme Mitteldeutschl. 25: 71, 1857, Crepidotaceae, found in plot Csörötnek 1 (I, III), Orfalu 1 (III), 2 (I) and Öriszentpéter 3 (III), in stand type 1, 3, 4 and 6, on dead wood of broadleaved and coniferous trees.

Crepidotus variabilis (Pers.) P. Kumm., Führ. Pilzk. (Zwickau): 74, 1871, Crepidotaceae, found in plot Alsószölnök 2 (II), Apátistvánfalva (III), Csörötnek 1 (I), 3, 5 (III), Orfalu 1 (III), Öriszentpéter 3 (III), 4 (II, III), Szakonyfalu 1 (II, III), Szalafö 1-4, 7 (III), Szentgotthárd 1 (III) and 2, 4 (I, III), in stand type 1-6, on dead wood of broadleaved trees.

Crepidotus versutus* (Peck) Sacc., Syll. Fung. (Abellini) 5: 888, 1887, Crepidotaceae, found in plot Szakonyfalu 2 (II), in stand type 2, on decaying wood of Fagus sylvatica. Specimen examined: ORS-ERDO 152-26-2 (May 29, 2010). Spores 11.8-12.9 × $6.5 \mu \mathrm{m}$, av. $12.7 \times$ $6.5 \mu \mathrm{m}, \mathrm{Qav}=1.976, \mathrm{n}=7$, amygdaloid; cheilocystidia not branched.

Cyathus striatus (Huds.) Willd., Fl. Berol. Prodr.: 399, 1787, Agaricaceae, found in plot Alsószölnök 2 (I, III), Csörötnek 1 (I, III), 2 (III), 3 (I, III), 5 (III), 6 (I, III), Felsőszölnök 3 (I, III), Öriszentpéter 1 (I, III), Rábagyarmat (I), Szakonyfalu 1 (III), Szalafö 5, 6 (III) and Szentgotthárd 4 (I, III), in stand type 1-6, on leaf litter and decaying wood of Fagus sylvatica and Carpinus betulus.

Cylindrobasidium laeve (Pers.) Chamuris, Mycotaxon 20: 587, 1984, Physalacriaceae, found in plot Öriszentpéter 2 (I), in stand type 6, on decaying wood of Carpinus betulus.

Cystoderma amianthinum (Scop.) Fayod, Annls Sci. Nat. Bot., sér. 7, 9: 351, 1889, Agaricaceae, found in plot Apátistvánfalva (III) and Szalafó 1, 3 (III), in stand type 4 and 6, on mixed (needle and leaf) litter.

Cystodermella cinnabarina (Alb. \& Schwein.) Harmaja, Karstenia 42: 45, 2002, Agaricaceae, found in plot Szalafö 4 (III), in stand type 6, on mixed (needle and leaf) litter.

Cystolepiota seminuda (Lasch) Bon, Docums. Mycol. 6(24): 43, 1976, Agaricaceae, found in plot Alsószölnök 2 (III) and Csörötnek 1 (III), in stand type 1 and 5, mainly on leaf, sometimes on mixed (needle and leaf) litter.

Dacrymyces capitatus* Schwein., Trans. Am. Phil. Soc., ser. 2, 4(2): 186, 1832, Dacrymycetaceae, found in plot Csörötnek 1 (I), Felsőszölnök 3 (I), Öriszentpéter 2 (III) and Szentgotthárd 1 (I), in stand type 1, 4 and 6, on dead wood of broadleaved and coniferous trees. Specimen examined: ORS-ERDO 23/2 (August 4, 2009). Spores 10.8-12.9 × 4.3-6.5 $\mu \mathrm{m}$, av. $12.5 \times$ $5.8 \mu \mathrm{m}, \mathrm{Qav}=2.148, \mathrm{n}=5$; conidia 5.4-7.2 $\times 5.4 \mu \mathrm{m}$.

Dacrymyces chrysospermus* Berk. \& M.A. Curtis, Grevillea 2(14): 20, 1873, Dacrymycetaceae, found in plot Alsószölnök 2 (III) and Felsőszölnök 3 (I), in stand type 1 and 5, on decaying 
wood of Picea abies. Specimen examined: ORS-ERDO 142-63-1 (September 23, 2010). Spores 12.9-17.2 × 3.9-5.4 $\mu \mathrm{m}$, av. $14.6 \times 4.4 \mu \mathrm{m}$, Qav = 3.301, $\mathrm{n}=5$, with 5-7 septa.

Dacrymyces lacrymalis* (Pers.) Sommerf., Suppl. Fl. Lapp. (Oslo): 1753, 1826, Dacrymycetaceae, found in plot Szakonyfalu 2 (II), in stand type 2, on decaying wood of Fagus sylvatica. Specimen examined: ORS-ERDO 152-24-2 (May 29, 2010). Spores 12.9-14.4 × 4.3-6.0 $\mu \mathrm{m}$, av. $13.5 \times 4.6 \mu \mathrm{m}, \mathrm{Qav}=2.907, \mathrm{n}=5$, cylindrical, with $1-3$ septa.

Dacrymyces stillatus Nees, Syst. Pilze (Würzburg): 89, 1816, Dacrymycetaceae, found in plot Csörötnek 2 (I), Rábagyarmat (I) and Szakonyfalu 1 (II), in stand type 1-3, on decaying wood of Fagus sylvatica and Quercus petraea.

Daedalea quercina (L.) Pers., Syn. Meth. Fung. (Göttingen) 2: 500, 1801, Fomitopsidaceae, found in plot Magyarlak (I-III), Rábagyarmat (I-III) and Szalafö 2 (I-III), in stand type 3, on decaying wood of Quercus petraea.

Daedaleopsis confragosa (Bolton) J. Schröt., Krypt.-Fl. Schlesien (Breslau) 3.1(25-32): 492, 1888, Polyporaceae, found in plot Csörötnek 1 (I, III), Kétvölgy 2 (I), Öriszentpéter 3 (III), Szakonyfalu 2 (I), Szalafö 1 (III) and 4 (I), in stand type 1-3 and 6, on dead wood of broadleaved trees.

Daedaleopsis tricolor (Bull.) Bond. \& Sing., Annls Mycol. 39(1): 64, 1941, Polyporaceae, found in plot Felsőszölnök 2 (III) and Szalafö 5 (III), in stand type 1 and 4, on decaying wood of Fagus sylvatica and Quercus petraea.

Daldinia concentrica (Bolton) Ces. \& De Not., Comm. Soc. Crittog. Ital. 1(4): 197, 1863, Xylariaceae, found in plot Szentgotthárd 2 (III), in stand type 3, on decaying wood of Betula pendula.

Datronia mollis (Sommerf.) Donk, Persoonia 4(3): 338, 1966, Polyporaceae, found in plot Felsőszölnök 2 (II), in stand type 1, on decaying wood of Fagus sylvatica.

Deconica inquilina (Fr.) Romagn., Revue Mycol. (Paris) 2(6): 244, 1937, Strophariaceae, found in plot Alsószölnök 2 (III), in stand type 5, on leaf litter.

Dentipellis fragilis (Pers.) Donk, Persoonia 2(2): 233, 1962, Hericiaceae, found in plot Alsószölnök 1 (I) and Orfalu 2 (I), in stand type 4 and 6, on dead wood of broadleaved and coniferous trees.

Diatrype disciformis (Hoffm.) Fr., Summa veg. Scand. (Stockholm) 2: 385, 1849, Diatrypaceae, found in plot Csörötnek 3 (I), Felsőszölnök 1, 3 (I), Kétvölgy 1 (I), Orfalu 2 (I) and Szentgotthárd 3 (I), in stand type 1, 2 and 4, on decaying wood of Fagus sylvatica.

Diatrype stigma (Hoffm.) Fr., Summa veg. Scand. (Stockholm) 2: 385, 1849, Diatrypaceae, found in plot Apátistvánfalva (I), Csörötnek 3 (I), Felsőszölnök 1 (I), 2 (I), Kétvölgy 1 (I), Orfalu 1, 2 (I), Öriszentpéter 3 (I), Szakonyfalu 1 (I), Szalafö 3, 5 (I) and Szentgotthárd 3, 4 (I), in stand type 1-4 and 6, on decaying wood of Fagus sylvatica.

Diatrypella favacea (Fr.) Ces. \& De Not., Comm. Soc. Crittog. Ital. 1(4): 205, 1863, Diatrypaceae, found in plot Csörötnek 6 (I), Szalafö 1, 3 (I) and Szentgotthárd 2 (I), in stand type 3, 4 and 6, on decaying wood of Quercus petraea.

Diatrypella quercina (Pers.) Cooke, J. Bot. (London) 4: 99, 1866, Diatrypaceae, found in plot Orfalu 2 (I) and Öriszentpéter 3 (I), in stand type 3 and 4, on decaying wood of Quercus petraea.

Dichomitus campestris (Quél.) Dom. \& Orlicz, Acta Soc. Bot. Pol. 35: 627, 1966, Polyporaceae, found in plot Szalafó 7 (III), in stand type 4, on decaying wood of Quercus petraea.

Elaphocordyceps ophioglossoides (Ehrh.) G.H. Sung, J.M. Sung \& Spatafora, Stud. Mycol. 57: 37 , 2007, Ophiocordycipitaceae, found in plot Felsőszölnök 2 (III), Szakonyfalu 1 (I, III) and Szalafö 1 (III), in stand type 1 and 6, on sporocarp of Elaphomyces muricatus.

Elaphomyces muricatus Fr., Syst. Mycol. (Lundae) 3: 59, 1829, Elaphomycetaceae, found in plot Felsőszölnök 2 (III), 3 (I), Szakonyfalu 1 (I, III) and Szalafö 1 (III), in stand type 1 and 6, in soil. 
Entoloma conferendum var. pusillum (Velen.) Noordel., Persoonia 10(4): 450, 1980, Entolomataceae, found in plot Szakonyfalu 2 (III), in stand type 2, on mixed (needle and leaf) litter.

Entoloma hebes (Romagn.) Trimbach, Docums. Mycol. 11(44): 6, 1981, Entolomataceae, found in plot Csörötnek 1 (III) and Kétvölgy 2 (III), in stand type 1 and 2, mainly on leaf, sometimes on mixed (needle and leaf) litter.

Entoloma jahnii Wölfel \& Winterh., Öst. Z. Pilzk. 2: 14, 1993, Entolomataceae, found in plot Csörötnek 2 (I), in stand type 2, on decaying wood of Pinus sylvestris.

Entoloma juncinum (Kühner \& Romagn.) Noordel., Persoonia 10(2): 255, 1979, Entolomataceae, found in plot Csörötnek 1, 5 (III), Szalafö 2, 7 (III) and Szentgotthárd 2 (III), in stand type 1,3 and 4, on leaf litter.

Entoloma politum* (Pers.) Donk, Bull. Bot. Gdns Buitenz. 18: 158, 1949, Entolomataceae, found in plot Csörötnek 5 (III), Kétvölgy 2 (III), Szakonyfalu 1 (III) and Szalafö 5 (III), in stand type 1, 2 and 4, mainly on leaf, sometimes on mixed (needle and leaf) litter. Specimen examined: ORS-ERDO 151-13-2 (September 24, 2010). Spores 7.5-8.6 × 6.5-7.5 $\mu \mathrm{m}$, av. $8.2 \times 6.7 \mu \mathrm{m}, \mathrm{Qav}=1.226, \mathrm{n}=5$, five- or six-angled; basidia 4-spored; cheilocystidia absent; hyphae of pileipellis $6.5-15.1 \mu \mathrm{m}$ wide with intracellular pigments.

Entoloma rhodopolium (Fr.) P. Kumm., Führ. Pilzk. (Zwickau): 98, 1871, Entolomataceae, found in plot Alsószölnök 2 (III), Csörötnek 1, 3, 5, 6 (III), Felsőszölnök 3 (III), Orfalu 2 (III), Öriszentpéter 2, 3 (III), Szalafö 1, 5, 7 (III) and Szentgotthárd 2-4 (III), in stand type 1-6, mainly on leaf, sometimes on mixed (needle and leaf) litter.

Eutypa flavovirens (Pers.) Tul. \& C. Tul., Select. Fung. Carpol. (Paris) 2: 57, 1863, Diatrypaceae, found in plot Szakonyfalu 2 (I), in stand type 2, on decaying wood of Fagus sylvatica.

Exidia glandulosa (Bull.) Fr., Syst. Mycol. (Lundae) 2: 224, 1822, Auriculariaceae, found in plot Apátistvánfalva (III), Csörötnek 4-6 (III), Öriszentpéter 2 (III), Rábagyarmat (III), Szalafö 1, 2, 7 (III) and Szentgotthárd 2, 4 (III), in stand type 1, 3, 4 and 6, on dead wood of broadleaved trees.

Exidia nigricans (With.) P. Roberts, Mycotaxon 109: 220, 2009, Auriculariaceae, found in plot Alsószölnök 2 (II, III), Apátistvánfalva (II), Csörötnek 2-4 (II, III), 5 (III), 6 (II, III), Felsőszölnök 1 (II), 2 (I, III), 3 (I, II), Kétvölgy 1 (I, III), Magyarlak (III), Orfalu 1 (III), 2 (II, III), Öriszentpéter 1 (II), 2, 3 (II, III), Rábagyarmat (II), Szakonyfalu 1, 2 (II, III), Szalafö 1, 2 (III), 3, 4 (II, III), 5-7 (III), Szentgotthárd 1 (II, III), 2 (II), 3 (III) and 4 (II, III), in stand type 1-6, on dead wood of broadleaved trees.

Flammulaster carpophilus (Fr.) Earle, Persoonia 13(1): 7, 1986, Tubariaceae, found in plot Öriszentpéter 3 (III), in stand type 3, on buried decaying wood of Quercus petraea.

Flammulaster limulatus var. lituus* Vellinga, Persoonia 13(1): 17, 1986, Tubariaceae, found in plot Csörötnek 1 (II), in stand type 1, on decaying wood of Carpinus betulus. Specimen examined: ORS-ERDO 116-44-2 (May 30, 2010). Spores 6.2-6.9 × 4.1-4.3 $\mu \mathrm{m}$, av. $6.5 \times$ $4.3 \mu \mathrm{m}, \mathrm{Qav}=1.522, \mathrm{n}=8$, amygdaloid.

Fomes fomentarius (L.) Fr., Summa veg. Scand. (Stockholm) 2: 237, 1849, Polyporaceae, found in plot Öriszentpéter 3 (II, III) and Szalafö 2 (I, II), in stand type 3, on dead wood of broadleaved trees.

Fomitiporia punctata (P. Karst.) Murrill, Lloydia 10: 254, 1947, Hymenochaetaceae, found in plot Szentgotthárd 2 (I, III), in stand type 3, on decaying wood of Corylus avellana.

Fomitiporia robusta (P. Karst.) Fiasson \& Niemelä, Karstenia 24: 25, 1984, Hymenochaetaceae, found in plot Csörötnek 1 (I) and Szalafö 5 (III), in stand type 1 and 4, on decaying wood of Quercus petraea.

Fomitopsis pinicola (Sw.) P. Karst., Meddn Soc. Fauna Flora Fenn. 6: 9, 1881, Fomitopsidaceae, found in plot Kétvölgy 2 (I), in stand type 2, on decaying wood of Picea abies.

Fuscoporia contigua (Pers.) G. Cunn., Bull. N.Z. Dept. Sci. Industr. Res. 73: 4, 1948, Hymenochaetaceae, found in plot Alsószölnök 1 (I), Csörötnek 4 (I), 6 (II), Orfalu 2 (I), 
Öriszentpéter 3, 4 (I), Rábagyarmat (I), Szakonyfalu 2 (I), Szalafö 2 (III) and Szentgotthárd 1-3 (I), in stand type 2-4 and 6, on decaying wood of Quercus petraea.

Fuscoporia ferruginosa (Schrad.) Murrill, N. Amer. Fl. (New York) 9(1): 5, 1907, Hymenochaetaceae, found in plot Csörötnek 3 (I), Orfalu 2 (I) and Szentgotthárd 4 (I), in stand type 2, 4 and 6, on dead wood of broadleaved and coniferous trees.

Galerina cf. camerina (Fr.) Kühner, Encyclop. Mycol. 7: 212, 1935, Hymenogasteraceae, found in plot Szakonyfalu 1 (III), in stand type 1, on decaying wood of Pinus sylvestris.

Galerina marginata (Batsch) Kühner, Encyclop. Mycol. 7: 225, 1935, Hymenogasteraceae, found in plot Alsószölnök 2 (III), Csörötnek 2-6 (III), Felsőszölnök 3 (III), Kétvölgy 2 (III), Orfalu 1 (III), Öriszentpéter 1 (III), Szakonyfalu 1, 2 (III) and Szalafö 2-4, 7 (III), in stand type 1-6, on dead wood of broadleaved and coniferous trees.

Galerina cf. pallida (Pilát) E. Horak \& M.M. Moser, K1. Krypt.-Fl., Edn. 3 (Stuttgart) 2b/2: 347, 1967, Hymenogasteraceae, found in plot Öriszentpéter 4 (II), in stand type 6, on decaying wood of Pinus sylvestris.

Galerina pruinatipes* A.H. Sm., Mycologia 45(6): 912, 1953, Hymenogasteraceae, found in plot Apátistvánfalva (III), Csörötnek 5 (III), Orfalu 1 (III), Szakonyfalu 1 (III) and Szalafö 1-3, 7 (III), in stand type 1, 3, 4 and 6, on soil among mosses and on decaying wood of Quercus petraea. Specimen examined: ORS-ERDO 98-43-1 (September 21, 2010). Spores 11.1-11.1 $\times 6.3-7.9 \mu \mathrm{m}$, av. $11.1 \times 7.1 \mu \mathrm{m}, \mathrm{Qav}=1.556, \mathrm{n}=4$, amygdaloid to citriform; cheilocystidia $42.6-50.5 \times 9.5-15.8 \mu \mathrm{m}$, caulocystidia $34.7-74.2 \times 9.5-23.7 \mu \mathrm{m}$, pileocystidia $34.7-47.4 \times 9.5-12.6 \mu \mathrm{m}$, each type of cystidia utriform; hyphae of pileipellis 7.9-15.8 $\mu \mathrm{m}$ wide.

Galerina sideroides* (Bull.) Kühner, Encyclop. Mycol. 7: 215, 1935, Hymenogasteraceae, found in plot Csörötnek 6 (III), Felsőszölnök 3 (III) and Szakonyfalu 2 (III), in stand type 1, 2 and 4, on leaf litter and decaying wood of Pinus sylvestris. Specimen examined: ORS-ERDO 13841-1 (October 24, 2010). Spores 6.3-7.4 × 3.9-4.7 $\mu \mathrm{m}$, av. $6.9 \times 4.4 \mu \mathrm{m}$, Qav $=1.550, \mathrm{n}=$ 5; basidia 4-spored, cheilocystidia 11.1-23.7 × 1.6-4.7 $\mu \mathrm{m}$, capitate, caulocystidia narrowly cylindrical; pileipellis with clamped, gelatinous hyphae, $11.1-23.7 \mu \mathrm{m}$ wide.

Galerina triscopa (Fr.) Kühner, Encyclop. Mycol. 7: 206, 1935, Hymenogasteraceae, found in plot Öriszentpéter 4 (III), in stand type 6, among mosses and on dead wood of broadleaved and coniferous trees.

Ganoderma applanatum (Pers.) Pat., Bull. Soc. Mycol. Fr. 5: 67, 1889, Ganodermataceae, found in plot Öriszentpéter 1 (I, III) and 3 (I), in stand type 3 and 6, on decaying wood of Fagus sylvatica and Carpinus betulus.

Gloeophyllum abietinum (Bull.) P. Karst., Bidr. Känn. Finl. Nat. Folk 37: 80, 1882, Gloeophyllaceae, found in plot Szalafö 3 (I), in stand type 4, on decaying wood of Picea abies.

Gloeophyllum sepiarium (Wulfen) P. Karst., Bidr. Känn. Finl. Nat. Folk 37: 79, 1882, Gloeophyllaceae, found in plot Orfalu 2 (I), in stand type 4, on decaying wood of Pinus sylvestris.

Gloeoporus dichrous (Fr.) Bres., Hedwigia 53: 74, 1913, Meruliaceae, found in plot Magyarlak (III), in stand type 3, on dead wood of broadleaved trees.

Gloeoporus taxicola (Pers.) Gilb. \& Ryvarden, Mycotaxon 22: 364, 1985, Meruliaceae, found in plot Felsöszölnök 2 (I), in stand type 1, on decaying wood of Pinus sylvestris.

Gomphidius roseus (Fr.) Fr., Epicr. Syst. Mycol. (Upsaliae): 319, 1838, Gomphidiaceae, found in plot Öriszentpéter 2 (III), in stand type 6, on mixed (needle and leaf) litter.

Guepiniopsis buccina (Pers.) L.L. Kenn., Mycologia 50(6): 888, 1959, Dacrymycetaceae, found in plot Szakonyfalu 1 (III), in stand type 1, on decaying wood of Fagus sylvatica.

Gymnopilus penetrans (Fr.) Murrill, Mycologia 4(5): 254, 1912, Strophariaceae, found in plot Apátistvánfalva (III), Csörötnek 3, 6 (III), Öriszentpéter 1, 2, 4 (III), Szakonyfalu 1 (III) and Szalafö 7 (III), in stand type 1, 2, 4 and 6, on decaying wood of Pinus sylvestris. 
Gymnopilus sapineus (Fr.) Murrill, Mycologia 4(5): 254, 1912, Strophariaceae, found in plot Csörötnek 3 (III), Felsőszölnök 1 (III), Kétvölgy 2 (III) and Öriszentpéter 1 (III), in stand type 1, 2 and 6, on dead wood of coniferous trees.

Gymnopus androsaceus (L.) J.L. Mata \& R.H. Petersen, Mycoscience 45(3): 220, 2004, Marasmiaceae, found in plot Alsószölnök 1 (III), Apátistvánfalva (III), Orfalu 1 (I, III), Öriszentpéter 2, 4 (III), Szalafö 1, 4 (III) and Szentgotthárd 4 (III), in stand type 6, on mixed (needle and leaf) litter.

Gymnopus aquosus (Bull.) Antonín \& Noordel., Mycotaxon 63: 363, 1997, Marasmiaceae, found in plot Alsószölnök 2 (II), Csörötnek 1 (II), Felsőszölnök 3 (II), Kétvölgy 1, 2 (II), Öriszentpéter 1, 2, 4 (II), Szakonyfalu 1, 2 (II), Szalafő 1, 2, 4, 5, 7 (II) and Szentgotthárd 2, 4 (II), in stand type 1-6, mainly on mixed (needle and leaf), sometimes on leaf litter.

Gymnopus confluens (Pers.) Antonín, Halling \& Noordel., Mycotaxon 63: 364, 1997, Marasmiaceae, found in plot Alsószölnök 2 (I, III), Csörötnek 5, 6 (III), Felsőszölnök 2 (III) and Szalafö 7 (III), in stand type 1, 4 and 5, on leaf litter.

Gymnopus dryophilus (Bull.) Murrill, N. Amer. Fl. (New York) 9(5): 362, 1916, Marasmiaceae, found in plot Csörötnek 1 (III), Öriszentpéter 3 (III), Szalafö 1 (III), Szentgotthárd 1 (III) and 2 (I), in stand type 1, 3, 4 and 6, mainly on leaf, sometimes on mixed (needle and leaf) litter.

Gymnopus erythropus (Pers.) Antonín, Halling \& Noordel., Mycotaxon 63: 364, 1997 , Marasmiaceae, found in plot Csörötnek 1, 3, 5 (III), Orfalu 1 (III), Öriszentpéter 2-4 (III), Rábagyarmat (III), Szalafó 2 (III) and Szentgotthárd 1 (III), in stand type 1-4 and 6, on leaf litter.

Gymnopus fusipes (Bull.) Gray, Nat. Arr. Brit. Pl. (London) 1: 604, 1821, Marasmiaceae, found in plot Csörötnek 1 (III) and Öriszentpéter 3 (I, III), in stand type 1 and 3, on leaf litter and dead wood of broadleaved trees.

Gymnopus ocior (Pers.) Antonín \& Noordel., Mycotaxon 63: 365, 1997, Marasmiaceae, found in plot Szalafö 1, 2 (III), in stand type 3 and 6, mainly on leaf, sometimes on mixed (needle and leaf) litter.

Gymnopus peronatus (Bolton) Antonín, Halling \& Noordel., Nat. Arr. Brit. Pl. (London) 1: 607, 1821, Marasmiaceae, found in plot Csörötnek 1 (I, III), 3, 5, 6 (III), Felsőszölnök 2, 3 (III), Kétvölgy 1 (III), Magyarlak (III), Orfalu 2 (III), Öriszentpéter 1, 3, 4 (III), Szalafö 1, 3, 5-7 (III), Szentgotthárd 1 (III) and 2-4 (I, III), in stand type 1-4 and 6, mainly on leaf, sometimes on mixed (needle and leaf) litter.

Gymnopus quercophilus (Pouzar) Antonín \& Noordel., Czech Mycol. 60(1): 25, 2008, Marasmiaceae, found in plot Apátistvánfalva (III), Szakonyfalu 2 (III) and Szentgotthárd 2 (II), in stand type 2, 3 and 6, mainly on leaf, sometimes on mixed (needle and leaf) litter.

Gyromitra infula (Schaeff.) Quél., Enchir. fung. (Paris): 272, 1886, Discinaceae, found in plot Szalafó 2 (III), in stand type 3, on decaying wood of Betula pendula.

Hapalopilus nidulans (Fr.) P. Karst., Revue Mycol. (Toulouse) 3(9): 18, 1881, Polyporaceae, found in plot Kétvölgy 2 (I), Orfalu 2 (I), Szalafö 7 (I) and Szentgotthárd 3, 4 (I), in stand type 2, 4 and 6, on dead wood of broadleaved trees.

Hebeloma birrus (Fr.) Sacc., Syll. Fung. (Abellini) 5: 794, 1887, Hymenogasteraceae, found in plot Alsószölnök 1 (III) and Szentgotthárd 2 (III), in stand type 3 and 6, mainly on leaf, sometimes on mixed (needle and leaf) litter.

Hebeloma candidipes* Bruchet, Bull. Mens. Soc. Linn. Lyon, 39 (suppl.): 125, 1970, Hymenogasteraceae, found in plot Kétvölgy 2 (III), in stand type 2, mainly on mixed (needle and leaf), sometimes on leaf litter. Specimen examined: ORS-ERDO 113-14-1b (October 17, 2010). Spores 10.0-12.5 × 5.6-6.9 $\mu \mathrm{m}$, av. $11.2 \times 6.2 \mu \mathrm{m}, \mathrm{Qav}=1.812, \mathrm{n}=$ 10 , amygdaloid to narrowly citriform, verruculose, moderately dextrinoid; cheilocystidia 4.4-5.6 $\mu \mathrm{m}$ wide at apex, ventricose, slender at upper part.

Hebeloma cavipes* Huijsman, Persoonia 2(1): 97, 1961, Hymenogasteraceae, found in plot Kétvölgy 1 (III), Öriszentpéter 3 (III) and Szalafö 2 (III), in stand type 1 and 3, on leaf litter. 
Specimen examined: ORS-ERDO 99-25-1b (September 22, 2010). Spores 10.0-12.8 × 5.6$6.9 \mu \mathrm{m}$, av. $11.1 \times 6.3 \mu \mathrm{m}, \mathrm{Qav}=1.773, \mathrm{n}=15$, amygdaloid to citriform, sometimes with loosening perispore, verrucose-verruculose, moderately to strongly dextrinoid; cheilocystidia $6.2-7.3 \mu \mathrm{m}$ wide at apex, cylindrical to clavate, subcapitate, widened both at apex and base.

Hebeloma crustuliniforme (Bull.) Quél., Mém. Soc. Émul. Montbéliard, sér. 2, 5: 128, 1872, Hymenogasteraceae, found in plot Csörötnek 5 (III), Felsőszölnök 1 (III) and Kétvölgy 1 (III), in stand type 1, on leaf litter.

Hebeloma hiemale Bres., Fung. Trident. 2(11-13): 52, 1892, Hymenogasteraceae, found in plot Csörötnek 6 (III) and Szalafö 1 (III), in stand type 4 and 6, mainly on mixed (needle and leaf), sometimes on leaf litter.

Hebeloma radicosum (Bull.) Ricken, Die Blätterpilze 1: 115, 1915, Hymenogasteraceae, found in plot Csörötnek 5 (III) and Felsőszölnök 3 (III), in stand type 1, mainly on mixed (needle and leaf), sometimes on leaf litter.

Hebeloma sacchariolens Quél., Bull. Soc. Amis Sci. Nat. Rouen, sér. 2, 15: 158, 1880, Hymenogasteraceae, found in plot Felsöszölnök 3 (III), in stand type 1, on leaf litter.

Hebeloma sordescens* Vesterh., Nordic Jl. Bot. 9(3): 307, 1989, Hymenogasteraceae, found in plot Alsószölnök 2 (III), Apátistvánfalva (III), Csörötnek 5 (III), Kétvölgy 1 (III), Öriszentpéter 2, 3 (III), Szakonyfalu 2 (III) and Szalafö 2, 3 (III), in stand type 1-6, mainly on mixed (needle and leaf), sometimes on leaf litter. Specimen examined: ORS-ERDO 12541-2b (September 19, 2010). Spores 8.8-10.3 × 4.7-5.6 $\mu \mathrm{m}$, av. 9.3 $\times 5.0 \mu \mathrm{m}$, $\mathrm{Qav}=1.863$, $\mathrm{n}=5$, narrowly amygdaloid to citriform, verruculose to distinctly verrucose, fairly strongly to strongly dextrinoid, sometimes with loosening perispore; cheilocystidia cylindrical to ventricose, lageniform with a widened lower part, apical part 3.0-8.0 $\mu \mathrm{m}$ wide.

Hebeloma velutipes Bruchet, Bull. Mens. Soc. Linn. Lyon, 39 (suppl.): 127, 1970, Hymenogasteraceae, found in plot Alsószölnök 2 (III), Apátistvánfalva (III), Csörötnek 5 (III), Orfalu 1 (III), Öriszentpéter 2, 3 (III), Rábagyarmat (III), Szakonyfalu 1, 2 (III), Szalafö 2, 3 (III) and Szentgotthárd 2 (III), in stand type 1-6, mainly on leaf, sometimes on mixed (needle and leaf) litter.

Helvella elastica Bull., Herb. Fr. 6: tab. 242, 1785, Helvellaceae, found in plot Alsószölnök 2 (III) and Felsőszölnök 2, 3 (III), in stand type 1 and 5, on soil among mixed (needle and leaf) litter.

Helvella lacunosa Afzel., K. Vetensk-Acad. Nya Handl. 4: 304, 1783, Helvellaceae, found in plot Felsőszölnök 3 (III) and Szalafö 2 (III), in stand type 1 and 3, on soil among leaf litter, sometimes on decaying wood of Quercus petraea.

Helvella macropus (Pers.) Gray, Bidr. Känn. Finl. Nat. Folk 19: 37, 1871, Helvellaceae, found in plot Szalafö 1, 2 (III), in stand type 3 and 6, on mixed (needle and leaf) litter.

Heterobasidion annosum (Fr.) Bref., Unters. Gesammtgeb. Mykol. (Liepzig) 8: 154, 1888, Bondarzewiaceae, found in plot Csörötnek 2 (I, III), Kétvölgy 2 (I, III), Orfalu 1 (I-III), Öriszentpéter 1, 4 (I, III), Szakonyfalu 1 (I-III), 2 (III), Szentgotthárd 1 (III) and 3 (I, II), in stand type 1, 2, 4 and 6, on decaying wood of Pinus sylvestris and Betula pendula.

Humaria hemisphaerica (F.H. Wigg.) Fuckel, Jb. Nassau. Ver. Naturk. 23-24: 322, 1870, Pyronemataceae, found in plot Csörötnek 1, 3, 5 (III), Felsőszölnök 3 (I, III), Kétvölgy 1, 2 (III), Öriszentpéter 3 (III), Szakonyfalu 2 (I, III), Szalafö 1-3, 5, 7 (III), Szentgotthárd 2 (I, III) and 4 (III), in stand type 1-4 and 6, on soil; mainly among leaf, sometimes among mixed (needle and leaf) litter.

Hydnellum concrescens (Pers.) Banker, Mem. Torrey Bot. Club 12: 157, 1906, Bankeraceae, found in plot Szalafö 2 (III), in stand type 3, on mixed (needle and leaf) litter.

Hydnum repandum L., Sp. Pl. 2: 1178, 1753, Hydnaceae, found in plot Alsószölnök 2 (III), Apátistvánfalva (I, III), Kétvölgy 1 (I, III), Orfalu 2 (III), Öriszentpéter 2 (III), Szakonyfalu 1 (I, III), Szalafö 1, 4 (III) and Szentgotthárd 1 (III), in stand type 1 and 4-6, mainly on mixed (needle and leaf), sometimes on leaf litter. 
Hydnum rufescens Pers., Observ. Mycol. (Lipsiae) 2: 95, 1800, Hydnaceae, found in plot Alsószölnök 2 (III), Apátistvánfalva (I, III), Csörötnek 1, 3, 5 (III), Felsőszölnök 2 (III), Kétvölgy 1 (III), Orfalu 1, 2 (III), Öriszentpéter 2 (III), Szakonyfalu 1 (I, III) and Szalafö 4, 5, 7 (III), in stand type 1, 2 and 4-6, mainly on mixed (needle and leaf), sometimes on leaf litter.

Hydnum sp., Hydnaceae, found in plot Szakonyfalu 1 (III), in stand type 1, on mixed (needle and leaf) litter. Specimen examined: ORS-ERDO 151-31-3b (September 24, 2010). Spores 6.4$8.6 \times 6.4-8.6 \mu \mathrm{m}$, av. $8.0 \times 6.9 \mu \mathrm{m}, \mathrm{Qav}=1.150, \mathrm{n}=10$.

Hydropus subalpinus (Höhn.) Singer, Sydowia 15(1-6): 66, 1962, Marasmiaceae, found in plot Csörötnek 5 (III), in stand type 1, on leaf litter.

Hygrophoropsis aurantiaca (Wulfen) Maire, L'Empoisonnem. Champ. 99, 1921, Hygrophoropsidaceae, found in plot Alsószölnök 1 (III), Kétvölgy 2 (III), Öriszentpéter 4 (III), Szakonyfalu 1, 2 (III) and Szalafö 1 (III), in stand type 1, 2 and 6, on mixed (needle and leaf) litter.

Hygrophorus agathosmus (Fr.) Fr., Epicr. Syst. Mycol. (Upsaliae): 325, 1838, Hygrophoraceae, found in plot Alsószölnök 2 (III), in stand type 5, on mixed (needle and leaf) litter.

Hygrophorus eburneus (Bull.) Fr., Epicr. Syst. mycol. (Upsaliae): 321, 1838, Hygrophoraceae, found in plot Csörötnek 5 (III), Felsőszölnök 1-3 (III), Szalafő 7 (III) and Szentgotthárd 4 (III), in stand type 1, 4 and 6, mainly on leaf, sometimes on mixed (needle and leaf) litter.

Hygrophorus lindtneri M.M. Moser, Z. Pilzk. 33: 3, 1967, Hygrophoraceae, found in plot Alsószölnök 2 (III), in stand type 5, on mixed (needle and leaf) litter.

Hygrophorus penarioides Jacobsson \& E. Larss., Mycotaxon 99: 341, 2007, Hygrophoraceae, found in plot Alsószölnök 1 (III), in stand type 6, on mixed (needle and leaf) litter.

Hygrophorus persoonii Arnolds, Persoonia 10(3): 365, 1979, Hygrophoraceae, found in plot Öriszentpéter 1, 3 (III) and Szalafö 3 (III), in stand type 3, 4 and 6, mainly on leaf, sometimes on mixed (needle and leaf) litter.

Hygrophorus poëtarum R. Heim, Bull. Soc. Mycol. Fr. 63: 127, 1948, Hygrophoraceae, found in plot Apátistvánfalva (III), Felsőszölnök 1-3 (III) and Szentgotthárd 4 (III), in stand type 1 and 6, mainly on leaf, sometimes on mixed (needle and leaf) litter.

Hygrophorus russula (Schaeff.) Kauffman, Publications Mich. Geol. Biol. Surv., Biol. Ser. 5, 26: 185, 1918, Hygrophoraceae, found in plot Szalafö 3, 5 (III), in stand type 4, mainly on leaf, sometimes on mixed (needle and leaf) litter.

Hygrophorus unicolor Gröger, Z. Mykol. 46(2): 160, 1980, Hygrophoraceae, found in plot Felsöszölnök 3 (III), in stand type 1, on mixed (needle and leaf) litter.

Hymenochaete rubiginosa (Dicks.) Lév., Annls Sci. Nat. Bot., sér. 3, 5: 151, 1846, Hymenochaetaceae, found in plot Alsószölnök 2 (I, III), Apátistvánfalva (I, III), Csörötnek 1, 2, 4, 6 (I, III), Felsőszölnök 1, 3 (I), Magyarlak (I, III), Orfalu 1 (I, III), 2 (I), Öriszentpéter 3 (I), 4 (I, III), Rábagyarmat (I, III), Szakonyfalu 1 (III), 2 (I), Szalafö 2, 3, 5, 6 (I, III), 7 (III), Szentgotthárd 1, 2 (I, III) and 3 (I), in stand type 1-6, on decaying wood of Quercus petraea.

Hymenopellis radicata (Relhan) R.H. Petersen, Nova Hedwigia, Beih. 137: 202, 2010, Physalacriaceae, found in plot Alsószölnök 1, 2 (I, III), Apátistvánfalva (I), Csörötnek 1 (I, III), 2 (I), 3 (III), 4 (I), 5 (III), Felsöszölnök 1 (I, III), 2 (I), 3 (I, III), Kétvölgy 2 (III), Orfalu 1 (III), Öriszentpéter 2 (III), 3 (I, III), Szakonyfalu 1, 2 (III), Szalafö 1 (I) and 2 (III), in stand type 1-3, 5 and 6, on buried decaying wood of broadleaved trees.

Hypholoma capnoides (Fr.) P. Kumm., Führ. Pilzk. (Zwickau): 72, 1871, Strophariaceae, found in plot Szakonyfalu 2 (III) and Szalafó 1 (III), in stand type 2 and 6, on decaying wood of Pinus sylvestris.

Hypholoma fasciculare (Huds.) P. Kumm., Führ. Pilzk. (Zwickau): 72, 1871, Strophariaceae, found in plot Csörötnek 1 (III), 5 (I, III), Felsőszölnök 2, 3 (III), Kétvölgy 1, 2 (III), Orfalu 1 (I, III), Rábagyarmat (III), Szakonyfalu 1 (II, III), 2 (III), Szalafó 1 (I, III), 5,7 (III), 
Szentgotthárd 1 (III) and 3 (I-III), in stand type 1-4 and 6, on dead wood of broadleaved and coniferous trees.

Hypholoma lateritium (Schaeff.) P. Kumm., Führ. Pilzk. (Zwickau): 72, 1871, Strophariaceae, found in plot Csörötnek 1, 2, 5 (III), Orfalu 1 (III), Rábagyarmat (III), Szakonyfalu 2 (III), Szalafó 1 (III) and Szentgotthárd 2 (III), in stand type 1-3 and 6, on dead wood of broadleaved and coniferous trees.

Hypocrea citrina (Pers.) Fr., Summa veg. Scand. (Stockholm) 2: 383, 1849, Hypocreaceae, found in plot Csörötnek 2, 3, 6 (I), Felsőszölnök 1 (I, III), 2 (I), 3 (I, III), Kétvölgy 1 (I), Öriszentpéter 2, 3 (III), Rábagyarmat (I), Szakonyfalu 1, 2 (I, III), Szalafö 6 (I, III), 7 (I) and Szentgotthárd 3, 4 (I), in stand type 1-4 and 6, on decaying or living wood of Fagus sylvatica and Carpinus betulus.

Hypocrea gelatinosa (Tode) Fr., Summa veg. Scand. (Stockholm) 1: 383, 1846, Hypocreaceae, found in plot Csörötnek 1 (I), Kétvölgy 2 (I) and Szentgotthárd 3 (I), in stand type 1 and 2, on decaying wood of Fagus sylvatica and Quercus petraea.

Hypocrea rufa (Pers.) Fr., Summa veg. Scand. (Stockholm) 2: 383, 1849, Hypocreaceae, found in plot Szakonyfalu 1 (III), Szalafó 2 (III) and Szentgotthárd 2, 4 (I), in stand type 1, 3 and 6, on decaying wood of Quercus petraea and Fagus sylvatica.

Hypocrea sulphurea (Schwein.) Sacc., Syll. Fung. (Abellini) 2: 535, 1883, Hypocreaceae, found in plot Szalafö 1 (III), in stand type 6, on decaying wood of Quercus petraea.

Hypoxylon cf. ferrugineum G.H. Otth, Mitt. Naturf. Ges. Bern: 41, 1868, Xylariaceae, found in plot Öriszentpéter 1 (I), in stand type 6, on decaying wood of Tilia cordata.

Hypoxylon fragiforme (Pers.) J. Kickx f., FI. Crypt. Louvain (Bruxelles): 116, 1835, Xylariaceae, found in plot Alsószölnök 1 (I), Apátistvánfalva (I), Csörötnek 4 (I), Felsőszölnök 1-3 (I), Kétvölgy 1, 2 (I), Szakonyfalu 1, 2 (I), Szalafö 4 (I) and Szentgotthárd 1, 3, 4 (I), in stand type 1-4 and 6, on decaying wood of Fagus sylvatica.

Hypoxylon fuscum (Pers.) Fr., Summa veg. Scand. (Stockholm) 2: 384, 1849, Xylariaceae, found in plot Csörötnek 6 (I), Öriszentpéter 2 (I) and Szentgotthárd 2 (I), in stand type 3, 4 and 6, on dead wood of broadleaved trees.

Hypoxylon howeanum Peck, Ann. Rep. N.Y. St. Mus. 24: 98, 1872, Xylariaceae, found in plot Csörötnek 1 (I), in stand type 1, on decaying wood of Carpinus betulus.

Hypoxylon rubiginosum (Pers.) Fr., Summa veg. Scand. (Stockholm) 2: 384, 1849, Xylariaceae, found in plot Alsószölnök 1 (I), Csörötnek 3, 6 (I) and Szentgotthárd 2 (I), in stand type 2-4 and 6 , on dead wood of broadleaved trees.

Infundibulicybe gibba (Pers.) Harmaja, Ann. Bot. Fenn. 40(3): 217, 2003, Tricholomataceae, found in plot Apátistvánfalva (III), Csörötnek 1, 5 (III), Öriszentpéter 2-4 (III) and Szalafö 1, 2 (III), in stand type 1, 3 and 6, mainly on mixed (needle and leaf), sometimes on leaf litter.

Inocybe cf. amblyospora Kühner, Bull. Soc. Nat. Oyonnax 9(suppl.): 3, 1955, Crepidotaceae, found in plot Szalafo 4 (III), in stand type 6, on mixed (needle and leaf) litter.

Inocybe assimilata Britzelm., Ber. Naturhist. Augsburg 26: 137, 1881, Crepidotaceae, found in plot Csörötnek 2, 5, 6 (III), Orfalu 2 (III), Öriszentpéter 4 (III), Szakonyfalu 1, 2 (III), Szalafö 1 (II, III), 2, 7 (III) and Szentgotthárd 1 (III), in stand type 1-4 and 6, mainly on leaf, sometimes on mixed (needle and leaf) litter.

Inocybe asterospora Quél., Bull. Soc. Bot. Fr. 26: 50, 1879, Crepidotaceae, found in plot Csörötnek 1, 3, 5, 6 (III) and Rábagyarmat (III), in stand type 1-4, mainly on leaf, sometimes on mixed (needle and leaf) litter.

Inocybe cf. auricoma (Batsch) J.E. Lange, Dansk Bot. Ark. 2(7): 37, 1917, Crepidotaceae, found in plot Szentgotthárd 2 (III), in stand type 3, on leaf litter.

Inocybe calida Velen., České Houby 2: 366, 1920, Crepidotaceae, found in plot Alsószölnök 2 (III) and Szakonyfalu 1 (III), in stand type 1 and 5, mainly on leaf, sometimes on mixed (needle and leaf) litter. 
Inocybe castanea* Peck, Bull. N.Y. St. Mus. 75: 16, 1904, Crepidotaceae, found in plot Szalafö 4 (III), in stand type 6, on mixed (needle and leaf) litter. Specimen examined: ORS-ERDO 102-46-1 (October 20, 2010). Spores 6.9-8.8 × 5.0-5.9 $\mu \mathrm{m}$, av. 7.7 × 5.5 $\mu \mathrm{m}$, Qav = 1.393, $\mathrm{n}=10$, nodulose; hymenial cystidia lageniform, thick-walled, walls up to $3.0 \mu \mathrm{m}$.

Inocybe cervicolor (Pers.) Quél., Enchir. fung. (Paris): 95, 1886, Crepidotaceae, found in plot Felsőszölnök 2, 3 (III), in stand type 1, mainly on leaf, sometimes on mixed (needle and leaf) litter.

Inocybe cincinnata (Fr.) Quél., Mém. Soc. Émul. Montbéliard, sér. 2, 5: 179, 1872, Crepidotaceae, found in plot Alsószölnök 2 (III), Öriszentpéter 2 (III), Szakonyfalu 2 (III) and Szalafö 1, 2 , 7 (III), in stand type 2-6, mainly on mixed (needle and leaf), sometimes on leaf litter.

Inocybe flocculosa Sacc., Syll. Fung. (Abellini) 5: 768, 1887, Crepidotaceae, found in plot Szentgotthárd 4 (III), in stand type 6, on mixed (needle and leaf) litter.

Inocybe furfurea Kühner, Bull. Soc. Nat. Oyonnax 9(suppl.): 4, 1955, Crepidotaceae, found in plot Felsőszölnök 3 (III) and Öriszentpéter 3 (III), in stand type 1 and 3, on leaf litter.

Inocybe fuscidula Velen., České Houby 2: 378, 1920, Crepidotaceae, found in plot Felsőszölnök 2 (III), Kétvölgy 1 (III), Orfalu 2 (III), Öriszentpéter 3 (III) and Szalafö 2 (III), in stand type 1,3 and 4, on leaf litter.

Inocybe geophylla (Fr.) P. Kumm., Führ. Pilzk. (Zwickau): 78, 1871, Crepidotaceae, found in plot Csörötnek 6 (III), Felsőszölnök 1-3 (III), Kétvölgy 2 (III), Orfalu 2 (III), Öriszentpéter 1 (III), Szalafö 3, 7 (III) and Szentgotthárd 4 (III), in stand type 1, 2, 4 and 6, mainly on leaf, sometimes on mixed (needle and leaf) litter.

Inocybe grammata Quél. \& Le Bret., Bull. Soc. Amis Sci. Nat. Rouen, sér. 2, 15: 162, 1880, Crepidotaceae, found in plot Csörötnek 1 (III), in stand type 1, mainly on leaf, sometimes on mixed (needle and leaf) litter.

Inocybe hirtella Bres., Fung. Trident. 1(4-5): 52, 1884, Crepidotaceae, found in plot Alsószölnök 2 (III), Öriszentpéter 3 (III) and Szentgotthárd 4 (III), in stand type 3, 5 and 6, mainly on leaf, sometimes on mixed (needle and leaf) litter.

Inocybe jacobi Kühner, Bull. Soc. Mycol. Fr. 71: 170, 1956, Crepidotaceae, found in plot Kétvölgy 2 (III) and Szalafö 1 (III), in stand type 2 and 6, on mixed (needle and leaf) litter.

Inocybe leiocephala D.E. Stuntz, Mycologia 42(1): 98, 1950, Crepidotaceae, found in plot Felsőszölnök 3 (III), in stand type 1, on leaf litter.

Inocybe lilacina (Peck) Kauffman, Publications Mich. Geol. Biol. Surv., Biol. ser. 5, 26: 466, 1918, Crepidotaceae, found in plot Felsőszölnök 2, 3 (III), Kétvölgy 2 (III), Szalafö 3 (III) and Szentgotthárd 4 (III), in stand type 1, 2, 4 and 6, mainly on mixed (needle and leaf), sometimes on leaf litter.

Inocybe microspora J.E. Lange, Dansk Bot. Ark. 2(7): 38, 1917, Crepidotaceae, found in plot Öriszentpéter 2 (III), in stand type 6, on mixed (needle and leaf) litter.

Inocybe mixtilis (Britzelm.) Sacc., Syll. Fung. (Abellini) 5: 780, 1887, Crepidotaceae, found in plot Öriszentpéter 3 (III) and Szalafö 7 (III), in stand type 3 and 4, on leaf litter.

Inocybe nitidiuscula (Britzelm.) Lapl., Mém. Soc. Linn. Normandie: 523, 1894, Crepidotaceae, found in plot Kétvölgy 2 (III) and Szalafö 3 (III), in stand type 2 and 4, mainly on mixed (needle and leaf), sometimes on leaf litter.

Inocybe petiginosa (Fr.) Gillet, Hyménomycètes (Alençon): 521, 1876, Crepidotaceae, found in plot Alsószölnök 1, 2 (III), Apátistvánfalva (III), Csörötnek 3, 5 (III), Felsőszölnök 1-3 (III), Kétvölgy 1, 2 (III), Orfalu 2 (III), Öriszentpéter 2 (III), Szakonyfalu 1, 2 (III), Szalafö 2-7 (III) and Szentgotthárd 2, 4 (III), in stand type 1-6, mainly on mixed (needle and leaf), sometimes on leaf litter.

Inocybe praetervisa Quél., Fung. Trident. 1(3): 35, 1883, Crepidotaceae, found in plot Csörötnek 1, 4 (III) and Szentgotthárd 2 (III), in stand type 1 and 3, mainly on leaf, sometimes on mixed (needle and leaf) litter.

Inocybe pseudoreducta* Stangl \& Glowinski, Karstenia 21: 30, 1981, Crepidotaceae, found in plot Apátistvánfalva (III) and Csörötnek 1 (III), in stand type 1 and 6, on leaf litter. Specimen 
examined: ORS-ERDO 156-11-1b (October 19, 2010). Spores 7.5-9.7 × 5.0-5.6 $\mu \mathrm{m}$, av. $8.8 \times 5.4 \mu \mathrm{m}, \mathrm{Qav}=1.630, \mathrm{n}=10$, amygdaloid; hymenial cystidia 50.4-57.7 $\times 14.4-17.0$ $\mu \mathrm{m}$, lageniform, without crystals, thick-walled, walls up to $2.5 \mu \mathrm{m}$.

Inocybe putilla* Bres., Fung. Trident. 1(6-7): 81, 1887, Crepidotaceae, found in plot Alsószölnök 2 (III), in stand type 5, on mixed (needle and leaf) litter. Specimen examined: ORS-ERDO 142-21-1b (September 23, 2010). Spores 8.4-10.0 × 5.6-6.9 $\mu \mathrm{m}$, av. $9.1 \times 6.2 \mu \mathrm{m}$, Qav = $1.457, \mathrm{n}=10$, strongly nodulose; pleurocystidia abundant, 37.0-66.6 × 16.3-22.2 $\mu \mathrm{m}$, utriform, sometimes with long neck, with crystals at top, thin-walled, walls up to 1.5-2.0 $\mu \mathrm{m}$.

Inocybe rimosa (Bull.) P. Kumm., Führ. Pilzk. (Zwickau): 78, 1871, Crepidotaceae, found in plot Csörötnek 1 (III), in stand type 1, on leaf litter.

Inocybe sindonia (Fr.) P. Karst., Bidr. Känn. Finl. Nat. Folk 32: 465, 1879, Crepidotaceae, found in plot Csörötnek 1, 5 (III) and Kétvölgy 2 (III), in stand type 1 and 2, mainly on leaf, sometimes on mixed (needle and leaf) litter.

Inocybe soluta* Velen., České Houby 2: 365, 1920, Crepidotaceae, found in plot Csörötnek 3 (III) and Öriszentpéter 3 (III), in stand type 2 and 3, mainly on leaf, sometimes on mixed (needle and leaf) litter. Specimen examined: ORS-ERDO 118-16-2 (October 10, 2010). Spores 6.6$8.1 \times 5.0-6.6 \mu \mathrm{m}$, av. $7.3 \times 5.7 \mu \mathrm{m}$, Qav $=1.288, \mathrm{n}=20$, nodulose with not prominent nodules; pleurocystidia 44.4-57.7 × 13.3-17.8 $\mu \mathrm{m}$, utriform, subfusiform, thin-walled, walls up to $1.0-1.5 \mu \mathrm{m}$, with crystals.

Inocybe splendens R. Heim, Encyclop. Mycol. 1: 328, 1932, Crepidotaceae, found in plot Orfalu 2 (III), in stand type 4, on leaf litter.

Inonotus nidus-pici Pilát, Sb. Nár. Muz. Praze, B: 108, 1953, Hymenochaetaceae, found in plot Felsőszölnök 2 (I), in stand type 1, on decaying wood of Fagus sylvatica.

Irpex lacteus (Fr.) Fr., Elench. fung. (Greifswald) 1: 142, 1828, Meruliaceae, found in plot Felsőszölnök 2 (I) and Orfalu 1 (III), in stand type 1 and 6, on decaying wood of Fagus sylvatica.

Junghuhnia nitida (Pers.) Ryvarden, Persoonia 7(1): 18, 1972, Meruliaceae, found in plot Alsószölnök 1, 2 (I), Csörötnek 1, 3 (I), 5 (II), 6 (I), Felsőszölnök 2 (I, III), 3 (I), Kétvölgy 1 (I), Szalafö 1 (III) and Szentgotthárd 4 (III), in stand type 1, 2 and 4-6, on dead wood of broadleaved trees.

Kretzschmaria deusta (Hoffm.) P.M.D. Martin, Jl. S. Afr. Bot. 36(2): 80, 1970, Xylariaceae, found in plot Alsószölnök 2 (I) and Csörötnek 1 (I), in stand type 1 and 5, on decaying wood of Fagus sylvatica and Carpinus betulus.

Laccaria amethystina Cooke, Grevillea 12(63): 70, 1884, Hydnangiaceae, found in plot Alsószölnök 1, 2 (III), Apátistvánfalva (III), Csörötnek 1-6 (III), Felsőszölnök 1-3 (III), Kétvölgy 1, 2 (III), Magyarlak (III), Orfalu 1, 2 (III), Öriszentpéter 1-3 (III), Rábagyarmat (III), Szakonyfalu 1, 2 (III), Szalafö 1-7 (III) and Szentgotthárd 1-4 (III), in stand type 1-6, mainly on mixed (needle and leaf), sometimes on leaf litter.

Laccaria bicolor (Maire) P.D. Orton, Trans. Br. Mycol. Soc. 43(2): 280, 1960, Hydnangiaceae, found in plot Szalafö 2 (III), in stand type 3, on leaf litter.

Laccaria laccata (Scop.) Cooke, Grevillea 12(63): 70, 1884, Hydnangiaceae, found in plot Alsószölnök 1 (III), Csörötnek 1-6 (III), Felsőszölnök 1-3 (III), Kétvölgy 1, 2 (III), Magyarlak (III), Orfalu 2 (III), Öriszentpéter 1, 3 (III), Rábagyarmat (III), Szakonyfalu 2 (III), Szalafö 1-3, 5-7 (III) and Szentgotthárd 2-4 (III), in stand type 1-4 and 6, mainly on leaf, sometimes on mixed (needle and leaf) litter.

Lachnum cf. fasciculare Velen., Monogr. Discom. Bohem. (Prague): 247, 1934, Hyaloscyphaceae, found in plot Szentgotthárd 3 (I), in stand type 2, on decaying wood of Quercus petraea.

Lactarius acris (Bolton) Gray, Nat. Arr. Brit. Pl. (London) 1: 625, 1821, Russulaceae, found in plot Felsőszölnök 1 (III), 2 (I, III), 3 (III), Kétvölgy 1, 2 (III), Szalafö 4 (III) and Szentgotthárd 4 (III), in stand type 1, 2 and 6, mainly on leaf, sometimes on mixed (needle and leaf) litter. 
Lactarius aurantiacus (Pers.) Gray, Nat. Arr. Brit. Pl. (London) 1: 624, 1821, Russulaceae, found in plot Csörötnek 5 (III), Öriszentpéter 1 (III), Szakonyfalu 2 (III), Szalafö 1, 3 (III) and Szentgotthárd 1, 3, 4 (III), in stand type 1, 2, 4 and 6, mainly on mixed (needle and leaf), sometimes on leaf litter.

Lactarius bertillonii (Neuhoff ex Z. Schaef.) Bon, Docums. Mycol. 10(37-38): 92, 1980, Russulaceae, found in plot Szalafó 1 (III), in stand type 6, on mixed (needle and leaf) litter.

Lactarius blennius (Fr.) Fr., Epicr. Syst. Mycol. (Upsaliae): 337, 1838, Russulaceae, found in plot Alsószölnök 1 (III), Apátistvánfalva (III), Csörötnek 1, 3-6 (III), Felsőszölnök 1-3 (III), Kétvölgy 1, 2 (III), Orfalu 1 (III), Rábagyarmat (III), Szakonyfalu 1 (III), 2 (I, III), Szalafö 1-7 (III) and Szentgotthárd 2, 4 (III), in stand type 1-4 and 6, mainly on mixed (needle and leaf), sometimes on leaf litter.

Lactarius camphoratus (Bull.) Fr., Epicr. Syst. Mycol. (Upsaliae): 346, 1838, Russulaceae, found in plot Alsószölnök 1 (III), Apátistvánfalva (III), Csörötnek 3 (III), 4 (II, III), 5 (III), Kétvölgy 1 (III), Orfalu 1 (I, III), 2 (III), Öriszentpéter 3 (III), Rábagyarmat (III), Szakonyfalu 1, 2 (I, III), Szalafö 1, 2 (I, III), 3, 5 (III) and Szentgotthárd 1 (III), in stand type 1-4 and 6, mainly on mixed (needle and leaf), sometimes on leaf litter.

Lactarius chrysorrheus Fr., Epicr. Syst. Mycol. (Upsaliae): 342, 1838, Russulaceae, found in plot Alsószölnök 1 (III), Apátistvánfalva (III), Csörötnek 3, 4, 6 (III), Magyarlak (III), Orfalu 1, 2 (III), Szalafó 1 (I, III), 2-4, 6, 7 (III), Szentgotthárd 1 (III), 2 (I, III) and 3, 4 (III), in stand type 2-4 and 6, mainly on mixed (needle and leaf), sometimes on leaf litter.

Lactarius circellatus Fr., Epicr. Syst. Mycol. (Upsaliae): 338, 1838, Russulaceae, found in plot Csörötnek 1 (III), Öriszentpéter 2 (I) and 3 (III), in stand type 1, 3 and 6, on leaf litter.

Lactarius deterrimus Gröger, Westf. Pilzb. 7: 10, 1968, Russulaceae, found in plot Alsószölnök 2 (III), in stand type 5, on mixed (needle and leaf) litter.

Lactarius flexuosus (Pers.) Gray, Nat. Arr. Brit. P1. (London) 1: 624, 1821, Russulaceae, found in plot Orfalu 1 (III) and Szalafó 1 (III), in stand type 6, on mixed (needle and leaf) litter.

Lactarius fluens Boud., Bull. Soc. Mycol. Fr. 15: 49, 1899, Russulaceae, found in plot Szalafö 1, 2 (III), in stand type 3 and 6, on mixed (needle and leaf) litter.

Lactarius fuliginosus (Fr.) Fr., Epicr. Syst. Mycol. (Upsaliae): 348, 1838, Russulaceae, found in plot Apátistvánfalva (I), Öriszentpéter 3 (III), Szakonyfalu 1, 2 (III) and Szalafö 2 (I, III), in stand type 1-3 and 6, mainly on leaf, sometimes on mixed (needle and leaf) litter.

Lactarius glaucescens Crossl., Naturalist (London): 5, 1900, Russulaceae, found in plot Felsőszölnök 2, 3 (I), Kétvölgy 1 (I), 2 (III), Szakonyfalu 1 (I), Szalafő 5 (I) and Szentgotthárd 4 (I), in stand type 1,2, 4 and 6, mainly on mixed (needle and leaf), sometimes on leaf litter.

Lactarius glyciosmus (Fr.) Fr., Epicr. Syst. Mycol. (Upsaliae): 348, 1838, Russulaceae, found in plot Szalafó 1 (III), in stand type 6, on mixed (needle and leaf) litter.

Lactarius necator (Bull.) Pers., Observ. Mycol. (Lipsiae) 1: 42, 1796, Russulaceae, found in plot Kétvölgy 2 (III), Orfalu 1 (III) and Szalafö 1 (III), in stand type 2 and 6, on mixed (needle and leaf) litter.

Lactarius pallidus Pers., Tent. Disp. Meth. Fung. (Lipsiae): 64, 1797, Russulaceae, found in plot Felsőszölnök 2 (III), in stand type 1, mainly on leaf, sometimes on mixed (needle and leaf) litter.

Lactarius pterosporus Romagn., Revue Mycol. (Paris) 14: 108, 1949, Russulaceae, found in plot Felsőszölnök 3 (III), Öriszentpéter 2 (III), Szakonyfalu 1 (III) and Szalafö 2, 3 (III), in stand type 1, 3, 4 and 6, mainly on mixed (needle and leaf), sometimes on leaf litter.

Lactarius quieticolor Romagn., Revue Mycol. (Paris) 23: 280, 1958, Russulaceae, found in plot Apátistvánfalva (III), Csörötnek 6 (III), Orfalu 1 (III), Öriszentpéter 1, 2 (III) and Szalafö 1, 3, 4, 7 (III), in stand type 4 and 6, mainly on mixed (needle and leaf), sometimes on needle litter.

Lactarius quietus (Fr.) Fr., Epicr. Syst. Mycol. (Upsaliae): 343, 1838, Russulaceae, found in plot Alsószölnök 1, 2 (III), Csörötnek 3, 4, 6 (III), Öriszentpéter 2-4 (III), Rábagyarmat (III), 
Szakonyfalu 2 (III), Szalafö 1-3 (III) and Szentgotthárd 1-4 (III), in stand type 2-6, mainly on leaf, sometimes on mixed (needle and leaf) litter.

Lactarius rostratus Heilm.-Claus., Fungi of Northern Europe (Greve) 2: 216, 1998, Russulaceae, found in plot Alsószölnök 2 (III), Apátistvánfalva (III), Csörötnek 3, 4 (III), Felsőszölnök 3 (III), Kétvölgy 1, 2 (III), Orfalu 1 (III), Szakonyfalu 1 (I, III), 2 (III), Szalafő 2-4, 7 (III) and Szentgotthárd 2 (III), in stand type 1-6, mainly on leaf, sometimes on mixed (needle and leaf) litter.

Lactarius ruginosus Romagn., Bull. Soc. Mycol. Fr. 72: 340, 1957, Russulaceae, found in plot Öriszentpéter 2 (I) and Szalafö 7 (I), in stand type 4 and 6, on leaf litter.

Lactarius serifluus (DC.) Fr., Epicr. Syst. Mycol. (Upsaliae): 345, 1838, Russulaceae, found in plot Alsószölnök 1 (III), Csörötnek 1, 4, 5 (III), Öriszentpéter 1, 2 (III), Rábagyarmat (III), Szalafö 2, 3, 7 (III) and Szentgotthárd 1 (III), in stand type 1, 3, 4 and 6, mainly on leaf, sometimes on mixed (needle and leaf) litter.

Lactarius subdulcis (Pers.) Gray, Nat. Arr. Brit. Pl. (London) 1: 625, 1821, Russulaceae, found in plot Alsószölnök 1 (III), Csörötnek 1-6 (III), Felsöszölnök 1-3 (III), Kétvölgy 1, 2 (III), Magyarlak (III), Orfalu 1 (III), Öriszentpéter 1, 2 (III), Rábagyarmat (III), Szakonyfalu 1, 2 (III), Szalafö 1, 2, 5-7 (III) and Szentgotthárd 1-3 (III), in stand type 1-4 and 6, mainly on leaf, sometimes on mixed (needle and leaf) litter.

Lactarius torminosus (Schaeff.) Pers., Tent. Disp. Meth. Fung. (Lipsiae): 64, 1797, Russulaceae, found in plot Orfalu 1 (III) and Szalafö 1 (III), in stand type 6, on mixed (needle and leaf) litter.

Lactarius uvidus (Fr.) Fr., Epicr. Syst. Mycol. (Upsaliae): 338, 1838, Russulaceae, found in plot Csörötnek 2 (III), Öriszentpéter 2 (III) and Szalafö 5-7 (III), in stand type 2, 4 and 6, mainly on leaf, sometimes on mixed (needle and leaf) litter.

Lactarius vellereus (Fr.) Fr., Epicr. Syst. Mycol. (Upsaliae): 340, 1838, Russulaceae, found in plot Felsőszölnök 2 (III), Kétvölgy 1, 2 (III), Orfalu 1 (III), Öriszentpéter 1, 3 (III), Szakonyfalu 1, 2 (III), Szalafó 1, 3, 4, 7 (III) and Szentgotthárd 4 (III), in stand type 1-4 and 6, mainly on mixed (needle and leaf), sometimes on leaf litter.

Lactarius vietus (Fr.) Fr., Epicr. Syst. Mycol. (Upsaliae): 344, 1838, Russulaceae, found in plot Szalafo' 1 (III), in stand type 6, on mixed (needle and leaf) litter.

Laxitextum bicolor (Pers.) Lentz, U.S. Dept. Agric. Monogr. 24: 19, 1956, Hericiaceae, found in plot Csörötnek 5 (I, III), Felsöszölnök 1, 2 (I, III), Kétvölgy 1 (I, III), 2 (I), Rábagyarmat (I), Szakonyfalu 1), 2 (I, III) and Szentgotthárd 4 (I), in stand type 1-3 and 6, on decaying wood of Fagus sylvatica.

Leccinum aurantiacum (Bull.) Gray, Nat. Arr. Brit. Pl. (London) 1: 646, 1821, Boletaceae, found in plot Apátistvánfalva (III), Szakonyfalu 1 (III), Szalafó 1, 2 (III) and 3 (I, III), in stand type 1, 3, 4 and 6, mainly on leaf, sometimes on mixed (needle and leaf) litter.

Leccinum crocipodium (Letell.) Watling, Trans. \& Proc. Bot. Soc. Edinb. 39(2): 200, 1961, Boletaceae, found in plot Szentgotthárd 2 (I), in stand type 3, on leaf litter.

Leccinum cyaneobasileucum Lannoy \& Estadès, Docums. Mycol. 21(81): 23, 1991, Boletaceae, found in plot Szalafö 1 (III), in stand type 6, on mixed (needle and leaf) litter.

Leccinum pseudoscabrum (Kallenb.) Šutara, Česká Mykol. 43(1): 6, 1989, Boletaceae, found in plot Öriszentpéter 2 (I, III), 3 (I), Szakonyfalu 1 (I), Szalafö 2, 6, 7 (I) and Szentgotthárd 2 (I), in stand type 1, 3, 4 and 6, mainly on leaf, sometimes on mixed (needle and leaf) litter.

Lentinellus cochleatus (Pers.) P. Karst., Bidr. Känn. Finl. Nat. Folk 32: 247, 1879, Auriscalpiaceae, found in plot Csörötnek 1 (III), in stand type 1, on leaf litter.

Lentinellus flabelliformis (Bolton) S. Ito, Mycol. Fl. Japan 2: 151, 1959, Auriscalpiaceae, found in plot Felsöszölnök 2 (III), in stand type 1, on decaying wood of Fagus sylvatica.

Lentinellus ursinus (Fr.) Kühner, Botaniste 17: 99, 1926, Auriscalpiaceae, found in plot Csörötnek 1 (III), 5 (I) and Szalafö 1, 4 (III), in stand type 1 and 6, on dead wood of broadleaved and coniferous trees. 
Lenzites betulina (L.) Fr., Epicr. Syst. Mycol. (Upsaliae): 405, 1838, Polyporaceae, found in plot Felsőszölnök 3 (III), Kétvölgy 2 (III) and Orfalu 1 (III), in stand type 1, 2 and 6, on decaying wood of Betula pendula.

Leotia lubrica (Scop.) Pers., Comm. fung. clav. (Lipsiae): 31, 1797, Leotiaceae, found in plot Alsószölnök 1, 2 (III), Csörötnek 5 (III), Felsőszölnök 2, 3 (III), Kétvölgy 1, 2 (III), Orfalu 1, 2 (III), Öriszentpéter 2 (III), Szakonyfalu 1 (I, III), 2 (III), Szalafö 1-7 (III) and Szentgotthárd 4 (III), in stand type 1-6, on soil; mainly among leaf, sometimes among mixed (needle and leaf) litter.

Lepiota boudieri Bres., Fung. Trident. 1(4-5): 43, 1884, Agaricaceae, found in plot Csörötnek 1 (III), in stand type 1, on leaf litter.

Lepiota castanea Quél., Compt. Rend. Assoc. Franç. Avancem. Sci. 9: 661, 1881, Agaricaceae, found in plot Alsószölnök 2 (III), Csörötnek 1, 6 (III), Felsőszölnök 3 (III), Öriszentpéter 3 (III), Szakonyfalu 2 (III), Szalafö 7 (III) and Szentgotthárd 4 (III), in stand type 1-6, mainly on leaf, sometimes on mixed (needle and leaf) litter.

Lepiota clypeolaria (Bull.) P. Kumm., Führ. Pilzk. (Zwickau): 137, 1871, Agaricaceae, found in plot Alsószölnök 2 (III), Csörötnek 1, 3, 6 (III), Felsőszölnök 2, 3 (III), Orfalu 1 (III), Öriszentpéter 3 (III), Szakonyfalu 2 (III), Szalafö 4, 6 (III) and Szentgotthárd 4 (III), in stand type 1-6, mainly on mixed (needle and leaf), sometimes on leaf litter.

Lepiota cristata (Bolton) P. Kumm., Führ. Pilzk. (Zwickau): 137, 1871, Agaricaceae, found in plot Csörötnek 1 (III), Öriszentpéter 3 (III) and Szalafö 6 (III), in stand type 1, 3 and 4, on leaf litter.

Lepiota ignivolvata Bousset \& Joss. ex Joss., Riv. Micol. 33(1): 30, 1990, Agaricaceae, found in plot Alsószölnök 2 (III), Apátistvánfalva (III) and Felsőszölnök 2 (III), in stand type 1, 5 and 6, mainly on mixed (needle and leaf), sometimes on leaf litter.

Lepista flaccida (Sowerby) Pat., Hyménomyc. Eur. (Paris): 96, 1887, Tricholomataceae, found in plot Alsószölnök 2 (III), Kétvölgy 2 (III), Orfalu 1 (III), Öriszentpéter 1, 4 (III), Szalafö 4, 6 (III) and Szentgotthárd 2, 4 (III), in stand type 2-6, on mixed (needle and leaf) litter.

Lepista glaucocana (Bres.) Singer, Lilloa 22: 193, 1951, Tricholomataceae, found in plot Szakonyfalu 1 (III), in stand type 1, on mixed (needle and leaf) litter.

Lepista nuda (Bull.) Cooke, Handb. Brit. Fungi 1: 192, 1871, Tricholomataceae, found in plot Apátistvánfalva (III), Csörötnek 3, 5 (III), Kétvölgy 2 (III), Orfalu 1 (III), Szakonyfalu 2 (III), Szalafö 3-6 (III) and Szentgotthárd 1-4 (III), in stand type 1-4 and 6, mainly on leaf, sometimes on mixed (needle and leaf) litter.

Leucocortinarius bulbiger (Alb. \& Schwein.) Singer, Lloydia 8: 141, 1945, Tricholomataceae, found in plot Szalafo 3 (III), in stand type 4, on mixed (needle and leaf) litter.

Lycoperdon excipuliforme (Scop.) Pers., Syn. Meth. Fung. (Göttingen) 1: 143, 1801, Agaricaceae, found in plot Apátistvánfalva (III), Felsőszölnök 3 (III), Öriszentpéter 3 (III), Szakonyfalu 2 (III) and Szentgotthárd 1 (III), in stand type 1-4 and 6, on mixed (needle and leaf) litter.

Lycoperdon lividum Pers., J. Bot. (Desvaux) 2: 18, 1809, Agaricaceae, found in plot Szentgotthárd 1 (III), in stand type 4, on mixed (needle and leaf) litter.

Lycoperdon molle Pers., Observ. Mycol. (Lipsiae) 2: 70, 1800, Agaricaceae, found in plot Alsószölnök 1 (III), Apátistvánfalva (III), Csörötnek 3, 5 (III), Kétvölgy 1 (III), Orfalu 1 (III), Öriszentpéter 1 (III), 2 (I, III), 3, 4 (III), Szalafö 1, 4, 6 (III) and Szentgotthárd 4 (III), in stand type 1-4 and 6, on mixed (needle and leaf) litter.

Lycoperdon nigrescens Pers., Neues Mag. Bot. 1: 87, 1794, Agaricaceae, found in plot Alsószölnök 1 (III), Kétvölgy 2 (III), Öriszentpéter 1, 4 (III), Szakonyfalu 1, 2 (III) and Szalafö 1 (III), in stand type 1, 2 and 6, on mixed (needle and leaf) litter.

Lycoperdon perlatum Pers., Observ. Mycol. (Lipsiae) 1: 145, 1796, Agaricaceae, found in plot Alsószölnök 2 (III), Apátistvánfalva (I), Csörötnek 1, 3, 5 (III), Felsőszölnök 3 (III), Kétvölgy 2 (III), Magyarlak (III), Orfalu 1 (III), 2 (I), Öriszentpéter 3 (III), 4 (I, III), Szakonyfalu 1, 2 (III), Szalafö 1 (III), 2 (I, III), 3, 5 (III), 6 (I, III), 7 (III), Szentgotthárd 1 
(I, III), 2 (III) and 3, 4 (I, III), in stand type 1-6, mainly on leaf, sometimes on mixed (needle and leaf) litter.

Lycoperdon pyriforme Willd., Fl. Berol. Prodr.: 411, 1787, Agaricaceae, found in plot Alsószölnök 2 (III), Apátistvánfalva (III), Csörötnek 1, 3, 5 (III), Felsőszölnök 2 (III), Kétvölgy 2 (III), Orfalu 1, 2 (III), Öriszentpéter 1 (I), 4 (III), Szakonyfalu 1 (III), Szalafö 1, 2, 6 (III) and Szentgotthárd 2 (III), in stand type 1-6, on dead wood of broadleaved and coniferous trees.

Lyophyllum baeospermum* Romagn., Bull. Soc. Nat. Oyonnax 8: 75, 1954, Lyophyllaceae, found in plot Öriszentpéter 4 (III), in stand type 6, on mixed (needle and leaf) litter. Specimen examined: ORS-ERDO 126-13-1 (September 20, 2010). Spores 3.9-4.7 × 3.2 $\mu \mathrm{m}$, av. $4.5 \times$ $3.2 \mu \mathrm{m}, \mathrm{Qav}=1.417, \mathrm{n}=5$; basidia av. $15.8 \times 4.7 \mu \mathrm{m}$, finely incrusted; cheilocystidia absent.

Lyophyllum boudieri* Kühner \& Romagn., Bull. Soc. Nat. Oyonnax 8: 75, 1954, Lyophyllaceae, found in plot Felsőszölnök 2 (III), in stand type 1, on leaf litter. Specimen examined: ORSERDO 147-46-1 (October 16, 2010). Spores 7.1-9.5 × 3.9-4.7 $\mu \mathrm{m}$, av. 8.1 × 4.4 $\mu \mathrm{m}$, Qav $=$ $1.846, \mathrm{n}=7$, finely verrucose; cheilocystidia absent; pileipellis with hyphae $12.6 \mu \mathrm{m}$ wide.

Lyophyllum leucophaeatum* (P. Karst.) P. Karst., Meddn. Soc. Fauna Flora Fenn. 6: 3, 1881, Lyophyllaceae, found in plot Csörötnek 1 (III) and Öriszentpéter 3 (III), in stand type 1 and 3 , on leaf litter. Specimen examined: ORS-ERDO 116-15-2b (September 25, 2010). Spores 5.0-7.2 $\times 3.3-4.5 \mu \mathrm{m}$, av. $6.1 \times 3.8 \mu \mathrm{m}, \mathrm{Qav}=1.580, \mathrm{n}=15$, ellipsoid to broadly ellipsoid (dacryoid), finely rough, amyloid; basidia siderophilous; cheilocystidia cylindrical, slightly capitate; hyphae of pileipellis 4.3-6.5 $\mu \mathrm{m}$ wide, clamped, with brown pigment.

Lyophyllum mephiticum (Fr.) Singer, Lilloa 22: 166, 1951, Lyophyllaceae, found in plot Csörötnek 1 (III), Szakonyfalu 2 (III), Szalafö 3 (III) and Szentgotthárd 1 (III), in stand type 1, 2 and 4, mainly on leaf, sometimes on mixed (needle and leaf) litter.

Lyophyllum platypum* Kühner, Bull. Soc. Nat. Oyonnax 8: 75, 1954, Lyophyllaceae, found in plot Alsószölnök 2 (III), Csörötnek 1 (III), Kétvölgy 2 (III), Öriszentpéter 2 (III) and Szalafö 1, 3, 4 (III), in stand type 1, 2 and 4-6, on mixed (needle and leaf) litter. Specimen examined: ORS-ERDO 98-65-2 (September 21, 2010). Spores 4.3-5.4 × 2.2-4.3 $\mu \mathrm{m}$, av. $4.5 \times 3.7 \mu \mathrm{m}$, Qav $=1.199, \mathrm{n}=9$; cheilocystidia absent; pileipellis with incrusted hyphae (3.2)-6.3-12.6 $\mu \mathrm{m}$ wide.

Lyophyllum rancidum (Fr.) Singer, Annls Mycol. 41(1-3): 103, 1943, Lyophyllaceae, found in plot Apátistvánfalva (III), in stand type 6, on mixed (needle and leaf) litter.

Macrocystidia cucumis (Pers.) Joss., Bull. Soc. Mycol. Fr. 49: 373, 1934, Macrocystidiaceae, found in plot Csörötnek 1 (III), in stand type 1, on leaf litter.

Macrolepiota mastoidea (Fr.) Singer, Lilloa 22: 417, 1951, Agaricaceae, found in plot Öriszentpéter 4 (III), in stand type 6, on mixed (needle and leaf) litter.

Macrolepiota procera (Scop.) Singer, Pap. Mich. Acad. Sci. 32: 141, 1948, Agaricaceae, found in plot Alsószölnök 1 (III), Csörötnek 5, 6 (III), Öriszentpéter 1 (I), Rábagyarmat (III) and Szakonyfalu 1 (III), in stand type 1, 3, 4 and 6, mainly on leaf, sometimes on mixed (needle and leaf) litter.

Macrotyphula juncea (Alb. \& Schwein.) Berthier, Bull. Mens. Soc. Linn. Lyon, 43: 186, 1974, Typhulaceae, found in plot Orfalu 1 (III), Öriszentpéter 4 (III), Szakonyfalu 2 (III) and Szalafö 1, 2, 4 (III), in stand type 2, 3 and 6, on mixed (needle and leaf) litter.

Marasmiellus ramealis (Bull.) Singer, Pap. Mich. Acad. Sci. 32: 130, 1948, Marasmiaceae, found in plot Csörötnek 1 (I-III), 3 (III), Öriszentpéter 2 (III), Rábagyarmat (III), Szalafö 4 (III) and Szentgotthárd 2 (I), in stand type 1-3 and 6, on dead wood of broadleaved trees.

Marasmius bulliardii Quél., Bull. Soc. Bot. Fr. 24: 323, 1878, Marasmiaceae, found in plot Csörötnek 1 (III), 5 (II), Kétvölgy 2 (III), Öriszentpéter 3 (I), 4 (III), Szalafö 1, 2 (III) and Szentgotthárd 2 (I), in stand type 1-3 and 6, mainly on leaf, sometimes on mixed (needle and leaf) litter or on dead wood of broadleaved and coniferous trees. 
Marasmius cohaerens (Pers.) Cooke \& Quél., Clavis Syn. Hymen. Europ. (London): 153, 1878, Marasmiaceae, found in plot Csörötnek 1, 6 (III) and Öriszentpéter 3 (III), in stand type 1, 3 and 4, on leaf litter.

Marasmius epiphyllus (Pers.) Fr., Epicr. Syst. Mycol. (Upsaliae): 386, 1838, Marasmiaceae, found in plot Szalafö 2 (III), in stand type 3, on leaf litter.

Marasmius rotula (Scop.) Fr., Epicr. Syst. Mycol. (Upsaliae): 385, 1838, Marasmiaceae, found in plot Csörötnek 1, 5, 6 (I), Öriszentpéter 3 (I, III), Szalafö 2 (III) and Szentgotthárd 2 (I), in stand type 1, 3 and 4, mainly on leaf litter, sometimes on dead wood of broadleaved trees.

Marasmius setosus (Sowerby) Noordel., Persoonia 13(3): 241, 1987, Marasmiaceae, found in plot Kétvölgy 2 (III), in stand type 2, on mixed (needle and leaf) litter.

Marasmius torquescens Quél., Mém. Soc. Émul. Montbéliard, sér. 2, 5: 221, 1872, Marasmiaceae, found in plot Alsószölnök 2 (III), Csörötnek 1 (I, III), 6 (III), Öriszentpéter 3 (III) and Szalafó 6 (III), in stand type 1 and 3-5, mainly on leaf, sometimes on mixed (needle and leaf) litter.

Marasmius wynneae Berk. \& Broome, Ann. Mag. Nat. Hist., ser. 3, 3: 358, 1859, Marasmiaceae, found in plot Csörötnek 1 (III), in stand type 1, on leaf litter.

Melogramma campylosporum Fr., Summa veg. Scand., Section Post. (Stockholm): 386, 1849, Melanconidaceae, found in plot Alsószölnök 2 (I), in stand type 5, on decaying wood of Carpinus betulus.

Mensularia nodulosa (Fr.) T. Wagner \& M. Fisch., Mycol. Res. 105(7): 781, 2001, Hymenochaetaceae, found in plot Csörötnek 1 (III), 2 (II), 5 (III) and Felsőszölnök 2 (III), in stand type 1 and 2, on decaying wood of Fagus sylvatica.

Mollisia cinerella Sacc., Syll. Fung. (Abellini) 8: 338, 1889, Dermateaceae, found in plot Csörötnek 6 (I), in stand type 4, on decaying wood of Quercus petraea.

Mollisia ligni (Desm.) P. Karst., Bidr. Känn. Finl. Nat. Folk 19: 204, 1871, Dermateaceae, found in plot Csörötnek 6 (I) and Szentgotthárd 4 (I), in stand type 4 and 6, on decaying wood of Quercus petraea.

Mollisia lividofusca (Fr.) Rehm, Rabenh. Krypt.-Fl., Edn 2 (Leipzig) 1.3 (lief. 36): 576, 1891, Dermateaceae, found in plot Csörötnek 1 (I), in stand type 1, on decaying wood of Fagus sylvatica.

Mucidula mucida (Schrad.) Pat., Hyménomyc. Eur. (Paris): 96, 1887, Physalacriaceae, found in plot Csörötnek 1, 4 (III), Felsőszölnök 2, 3 (III) and Szakonyfalu 1 (III), in stand type 1 and 3 , on decaying wood of Fagus sylvatica.

Mycena cf. abramsii (Murrill) Murrill, Mycologia 8(4): 220, 1916, Mycenaceae, found in plot Csörötnek 1 (III) and Öriszentpéter 4 (III), in stand type 1 and 6, on leaf litter, sometimes on decaying wood of Quercus petraea.

Mycena acicula (Schaeff.) P. Kumm., Führ. Pilzk. (Zwickau): 109, 1871, Mycenaceae, found in plot Szalafö 2 (II), in stand type 3, on leaf litter.

Mycena amicta (Fr.) Quél., Mém. Soc. Émul. Montbéliard, sér. 2, 5: 243, 1872, Mycenaceae, found in plot Csörötnek 5 (III), Öriszentpéter 2 (II), Szakonyfalu 1 (II), Szalafö 3, 4 (III) and Szentgotthárd 4 (III), in stand type 1, 4 and 6, mainly on leaf, sometimes on mixed (needle and leaf) litter.

Mycena arcangeliana Bres., Contr. Bolus Herb.: 78, 1904, Mycenaceae, found in plot Alsószölnök 2 (III), Csörötnek 1, 5 (III), Felsőszölnök 2 (III), Szakonyfalu 1 (III) and Szalafő 1, 2 (III), in stand type 1, 3, 5 and 6, on leaf litter or among mosses, on decaying wood of Fagus sylvatica and Pinus sylvestris.

Mycena aurantiomarginata (Fr.) Quél., Mém. Soc. Émul. Montbéliard, sér. 2, 5: 240, 1872, Mycenaceae, found in plot Alsószölnök 2 (III), Apátistvánfalva (III), Csörötnek 6 (III), Orfalu 1 (III), Szakonyfalu 1, 2 (III), Szalafö 1-4, 7 (III) and Szentgotthárd 4 (III), in stand type $1-6$, on mixed (needle and leaf) litter. 
Mycena capillaris (Schumach.) P. Kumm., Führ. Pilzk. (Zwickau): 108, 1871, Mycenaceae, found in plot Kétvölgy 2 (III) and Öriszentpéter 2-4 (III), in stand type 2, 3 and 6, mainly on leaf, sometimes on mixed (needle and leaf) litter.

Mycena cinerella (P. Karst.) P. Karst., Bidr. Känn. Finl. Nat. Folk 32: 113, 1879, Mycenaceae, found in plot Szakonyfalu 1 (III), in stand type 1, on mixed (needle and leaf) litter.

Mycena clavicularis* (Fr.) Gillet, Hyménomycètes (Alençon): 257, 1876, Mycenaceae, found in plot Alsószölnök 2 (III) and Szentgotthárd 2 (III), in stand type 3 and 5, on mixed (needle and leaf) litter, sometimes on decaying wood of Quercus robur. Specimen examined: ORSERDO 130-46-2 (November 2, 2010). Spores 6.5-7.5 × 4.3 $\mu \mathrm{m}$, av. $6.8 \times 4.3 \mu \mathrm{m}$, Qav $=$ $1.575, \mathrm{n}=6$.

Mycena crocata (Schrad.) P. Kumm., Führ. Pilzk. (Zwickau): 108, 1871, Mycenaceae, found in plot Csörötnek 1 (III) and Felsöszölnök 3 (III), in stand type 1, on leaf litter.

Mycena diosma* Krieglst. \& Schwöbel, Z. Mykol. 48(1): 32, 1982, Mycenaceae, found in plot Csörötnek 1 (III) and Szakonyfalu 2 (III), in stand type 1 and 2, mainly on leaf, sometimes on mixed (needle and leaf) litter. Specimen examined: ORS-ERDO 116-26-3 (September 25, 2010). Spores 5.4-6.5 × 3.2-4.3 $\mu \mathrm{m}$, av. 5.9 $\times 3.8 \mu \mathrm{m}$, $\mathrm{Qav}=1.571, \mathrm{n}=4$.

Mycena epipterygia (Scop.) Gray, Nat. Arr. Brit. Pl. (London) 1: 619, 1821, Mycenaceae, found in plot Alsószölnök 1, 2 (III), Apátistvánfalva (III), Csörötnek 1 (III), Kétvölgy 1 (III), Orfalu 1 (III), Öriszentpéter 4 (III), Szakonyfalu 1, 2 (III), Szalafö 1-4, 6, 7 (III) and Szentgotthárd 4 (III), in stand type $1-6$, on litter.

Mycena erubescens Höhn., Sber. Akad. Wiss. Wien, Math.-Naturw. Kl., Abt. 1 122(1): 267, 1913, Mycenaceae, found in plot Szalafó 3 (III), in stand type 4, on base of living Quercus petraea.

Mycena cf. fagetorum (Fr.) Gillet, Hyménomycètes (Alençon): 274, 1876, Mycenaceae, found in plot Csörötnek 3 (III) and Szalafö 1 (III), in stand type 2 and 6, on mixed (needle and leaf) litter.

Mycena filopes (Bull.) P. Kumm., Führ. Pilzk. (Zwickau): 110, 1871, Mycenaceae, found in plot Alsószölnök 2 (III), Rábagyarmat (III) and Szalafö 1 (III), in stand type 3, 5 and 6, on mixed (needle and leaf) litter, sometimes on decaying wood of Pinus sylvestris.

Mycena flavescens Velen., České Houby 2: 323, 1920, Mycenaceae, found in plot Alsószölnök 2 (III), Csörötnek 5 (III), Magyarlak (III), Öriszentpéter 2-4 (III), Szalafö 1-3, 5 (III) and Szentgotthárd 1, 3 (III), in stand type 1-6, mainly on leaf, sometimes on mixed (needle and leaf) litter.

Mycena galericulata (Scop.) Gray, Nat. Arr. Brit. Pl. (London) 1: 619, 1821, Mycenaceae, found in plot Alsószölnök 2 (III), Apátistvánfalva (III), Csörötnek 3, 6 (III), Kétvölgy 1, 2 (III), Orfalu 1 (III), Öriszentpéter 3, 4 (III), Szakonyfalu 1, 2 (III), Szalafö 2, 7 (III) and Szentgotthárd 2 (III), in stand type 1-6, on litter, on dead wood of broadleaved and coniferous trees.

Mycena galopus var. galopus (Pers.) P. Kumm., Führ. Pilzk. (Zwickau): 108, 1871, Mycenaceae, found in plot Alsószölnök 2 (III), Csörötnek 1, 5 (III), Kétvölgy 2 (III), Orfalu 1 (III), Öriszentpéter 4 (III), Szakonyfalu 1, 2 (III) and Szalafö 1-5 (III), in stand type 1-6, mainly on leaf, sometimes on mixed (needle and leaf) litter.

Mycena galopus var. leucogala (Cooke) J.E. Lange, Fl. Agaric. Danic. 2: 36, 1936, Mycenaceae, found in plot Csörötnek 5 (III), Kétvölgy 1 (III), Öriszentpéter 4 (III) and Szalafö 1, 2, 6 (III), in stand type 1, 3, 4 and 6, mainly on leaf, sometimes on mixed (needle and leaf) litter.

Mycena haematopus (Pers.) P. Kumm., Führ. Pilzk. (Zwickau): 108, 1871, Mycenaceae, found in plot Alsószölnök 1, 2 (III), Csörötnek 1, 5 (III), Öriszentpéter 2 (III), Szakonyfalu 1, 2 (III) and Szalafó 1, 2 (III), in stand type 1-3, 5 and 6, on litter, on dead wood of broadleaved trees.

Mycena hiemalis* (Osbeck) Quél., Mém. Soc. Émul. Montbéliard, sér. 2, 5: 110, 1872, Mycenaceae, found in plot Öriszentpéter 2 (III) and Szalafö 2 (III), in stand type 3 and 6, on 
decaying wood of Quercus petraea. Specimen examined: ORS-ERDO 124-53-1 (September 20, 2010). Spores 6.5-8.6 × 3.2-4.7 $\mu \mathrm{m}$, av. $7.6 \times 4.2 \mu \mathrm{m}$, Qav $=1.810, \mathrm{n}=7$.

Mycena inclinata (Fr.) Quél., Mém. Soc. Émul. Montbéliard, sér. 2, 5: 105, 1872, Mycenaceae, found in plot Csörötnek 1 (III), Magyarlak (III), Öriszentpéter 4 (III), Rábagyarmat (III), Szalafó 2 (III) and Szentgotthárd 2 (III), in stand type 1, 3 and 6, on dead wood of broadleaved trees.

Mycena leptocephala (Pers.) Gillet, Hyménomycètes (Alençon): 267, 1876, Mycenaceae, found in plot Alsószölnök 2 (III), Öriszentpéter 3 (III) and Szalafö 1, 2 (III), in stand type 3, 5 and 6, mainly on mixed (needle and leaf), sometimes on leaf litter.

Mycena maculata P. Karst., Meddn. Soc. Fauna Flora Fenn. 19: 89, 1890, Mycenaceae, found in plot Apátistvánfalva (III), Csörötnek 1, 6 (III), Felsőszölnök 1 (III), Öriszentpéter 2-4 (III), Szakonyfalu 1 (III), Szalafö 1, 2 (III) and Szentgotthárd 2 (III), in stand type 1, 3, 4 and 6, on litter.

Mycena metata (Fr.) P. Kumm., Führ. Pilzk. (Zwickau): 109, 1871, Mycenaceae, found in plot Kétvölgy 2 (III), Rábagyarmat (III) and Szakonyfalu 2 (III), in stand type 2 and 3, on mixed (needle and leaf) litter.

Mycena pelianthina (Fr.) Quél., Mém. Soc. Émul. Montbéliard, sér. 2, 5: 102, 1872, Mycenaceae, found in plot Csörötnek 1 (III), in stand type 1, on leaf litter.

Mycena polyadelpha (Lasch) Kühner, Encyclop. Mycol. 10: 262, 1938, Mycenaceae, found in plot Szentgotthárd 1 (III), in stand type 4, on mixed (needle and leaf) litter.

Mycena polygramma (Bull.) Gray, Nat. Arr. Brit. Pl. (London) 1: 619, 1821, Mycenaceae, found in plot Alsószölnök 1 (III), Csörötnek 1, 3, 6 (III), Orfalu 1, 2 (III), Öriszentpéter 2-4 (III), Rábagyarmat (III), Szakonyfalu 2 (III), Szalafó 1-3, 5, 7 (III) and Szentgotthárd 1, 4 (III), in stand type 1-4 and 6, on base of living and decaying wood of Quercus petraea.

Mycena pseudocorticola Kühner, Encyclop. Mycol. 10: 687, 1938, Mycenaceae, found in plot Öriszentpéter 3 (III), in stand type 3, on base of living Quercus petraea.

Mycena pura (Pers.) P. Kumm., Führ. Pilzk. (Zwickau): 107, 1871, Mycenaceae, found in plot Alsószölnök 2 (III), Apátistvánfalva (III), Csörötnek 1-3, 5, 6 (III), Felsőszölnök 2, 3 (III), Kétvölgy 2 (III), Orfalu 1 (III), Öriszentpéter 1, 4 (III), Szakonyfalu 1, 2 (III), Szalafö 1, 2 , 4, 6, 7 (III) and Szentgotthárd 2, 4 (III), in stand type 1-6, mainly on leaf, sometimes on mixed (needle and leaf) litter.

Mycena cf. rebaudengi Robich, Riv. Micol. 44(1): 26 2001, Mycenaceae, found in plot Öriszentpéter 2 (III), in stand type 6, on mixed (needle and leaf) litter.

Mycena rhenana* Maas Geest. \& Winterh., Z. Mykol. 51(2): 247, 1985, Mycenaceae, found in plot Orfalu 2 (III), in stand type 4, on decaying cupule litter of Fagus sylvatica. Specimen examined: ORS-ERDO 131-52-1 (November 4, 2010). Spores 6.5-8.6 × 3.2-4.3 $\mu \mathrm{m}$, av. $7.0 \times 3.9 \mu \mathrm{m}, \mathrm{Qav}=1.793, \mathrm{n}=8$.

Mycena rosea Gramberg, Iconogr. Gen. Pl. 1: 36, 1912, Mycenaceae, found in plot Apátistvánfalva (III), Csörötnek 1 (III), Felsőszölnök 3 (III), Kétvölgy 2 (III), Öriszentpéter 2-4 (III) and Szalafö 2-4, 6 (III), in stand type 1-4 and 6, mainly on leaf, sometimes on mixed (needle and leaf) litter.

Mycena rosella (Fr.) P. Kumm., Führ. Pilzk. (Zwickau): 109, 1871, Mycenaceae, found in plot Alsószölnök 2 (III), Apátistvánfalva (III), Kétvölgy 2 (III), Öriszentpéter 3 (III) and Szakonyfalu 2 (III), in stand type 2, 3, 5 and 6, on mixed (needle and leaf) litter.

Mycena rubromarginata (Fr.) P. Kumm., Führ. Pilzk. (Zwickau): 109, 1871, Mycenaceae, found in plot Öriszentpéter 4 (III) and Szakonyfalu 1 (III), in stand type 1 and 6, on mixed (needle and leaf) litter, sometimes on decaying wood of Pinus sylvestris.

Mycena sanguinolenta (Alb. \& Schwein.) P. Kumm., Führ. Pilzk. (Zwickau): 108, 1871, Mycenaceae, found in plot Alsószölnök 1 (III), 2 (I, III), Apátistvánfalva (III), Csörötnek 1, 3, 5 (III), Felsőszölnök 1 (I), Orfalu 1 (III), Öriszentpéter 1-4 (III), Szakonyfalu 1-2 (III), Szalafó 1, 2, 4 (III) and Szentgotthárd 4 (III), in stand type 1-3, 5 and 6, mainly on mixed (needle and leaf), sometimes on leaf litter. 
Mycena silvae-nigrae Maas Geest. \& Schwöbel, Beitr. Kenntn. Pilze Mitteleur. 3: 149, 1987, Mycenaceae, found in plot Öriszentpéter 4 (II) and Szentgotthárd 1 (III), in stand type 4 and 6, on decaying wood of Pinus sylvestris.

Mycena stipata Maas Geest. \& Schwöbel, Beitr. Kenntn. Pilze Mitteleur. 3: 147, 1987, Mycenaceae, found in plot Felsöszölnök 1, 3 (III) and Szakonyfalu 1 (III), in stand type 1, on dead wood of broadleaved and coniferous trees.

Mycena stylobates (Pers.) P. Kumm., Führ. Pilzk. (Zwickau): 108, 1871, Mycenaceae, found in plot Csörötnek 1 (I, III), 5 (III), Szalafö 1, 2 (III) and Szentgotthárd 4 (I), in stand type 1, 3 and 6 , on leaf litter.

Mycena viridimarginata* P. Karst., Hedwigia 31: 218, 1892, Mycenaceae, found in plot Szakonyfalu 2 (I), in stand type 2, on decaying wood of Pinus sylvestris. Specimen examined: ORS-ERDO 49/18 (August 8, 2009). Spores 10.8-12.9 ×6.5 $\mu \mathrm{m}$, av. $11.1 \times 6.5$ $\mu \mathrm{m}, \mathrm{Qav}=1.722, \mathrm{n}=6$, subglobose; cheilocystidia and caulocystidia lageniform.

Mycena vitilis (Fr.) Quél., Mém. Soc. Émul. Montbéliard, sér. 2, 5: 106, 1872, Mycenaceae, found in plot Csörötnek 1 (II, III), 2, 3, 5, 6 (III), Felsőszölnök 3 (III), Kétvölgy 2 (III), Magyarlak (III), Orfalu 1 (III), Öriszentpéter 2-4 (III), Rábagyarmat (III), Szakonyfalu 1 (III), 2 (II, III), Szalafó 1-7 (III) and Szentgotthárd 1, 2, 4 (III), in stand type 1-4 and 6, on needle and leaf litter, sometimes on dead wood of broadleaved trees.

Mycena vulgaris (Pers.) P. Kumm., Führ. Pilzk. (Zwickau): 108, 1871, Mycenaceae, found in plot Szakonyfalu 2 (III), in stand type 2, on decaying wood of Pinus sylvestris.

Mycena zephirus (Fr.) P. Kumm., Führ. Pilzk. (Zwickau): 110, 1871, Mycenaceae, found in plot Alsószölnök 2 (III), Apátistvánfalva (III), Csörötnek 1 (III), Orfalu 1 (III), Öriszentpéter 2, 4 (III), Szakonyfalu 1 (III) and Szalafó 1-3 (III), in stand type 1 and 3-6, on mixed (needle and leaf) litter.

Mycetinis alliaceus (Jacq.) Earle ex A.W. Wilson \& Desjardin, Mycologia 97(3): 677, 2005, Marasmiaceae, found in plot Alsószölnök 2 (III), Apátistvánfalva (III), Csörötnek 1 (I-III), 2-5 (III), Felsőszölnök 1-3 (III), Kétvölgy 1 (III), Orfalu 1 (III), Rábagyarmat (III), Szakonyfalu 1, 2 (III), Szalafö 5, 7 (III) and Szentgotthárd 3, 4 (III), in stand type 1-6, on leaf litter.

Mycetinis scorodonius (Fr.) A. Wilson \& Desjardin, Mycologia 97(3): 678, 2005, Marasmiaceae, found in plot Szalafo" 3 (III), in stand type 4, on leaf litter.

Mycoacia aurea (Fr.) J. Erikss. \& Ryvarden, Cortic. N. Eur. (Oslo) 4: 877, 1976, Meruliaceae, found in plot Szalafö 3 (I), in stand type 4, on decaying wood of Quercus petraea.

Mycoacia uda (Fr.) Donk, Medded. Nedl. Mycol. Ver. 18-20: 151, 1931, Meruliaceae, found in plot Felsöszölnök 3 (I), in stand type 1, on decaying wood of Quercus petraea.

Naucoria bohemica* Velen., České Houby 3: 527, 1921, Hymenogasteraceae, found in plot Csörötnek 1 (III), Öriszentpéter 4 (III), Szakonyfalu 1 (III) and Szalafö 1 (III), in stand type 1 and 6, mainly on leaf, sometimes on mixed (needle and leaf) litter. Specimen examined: ORS-ERDO 126-64-1b (September 20, 2010). Spores 11.9-13.8 × 6.3-7.8 $\mu \mathrm{m}$, av. $12.8 \times$ $7.4 \mu \mathrm{m}, \mathrm{Qav}=1.726, \mathrm{n}=10$, citriform, moderately dextrinoid, coarsely verrucose.

Nemania atropurpurea* (Fr.) Pouzar, Česká Mykol. 39(1): 19, 1985, Xylariaceae, found in plot Apátistvánfalva (I), in stand type 6, on decaying wood of Quercus petraea. Specimen examined: ORS-ERDO 47/7 (August 8, 2009). Spores 10.8-12.9 × 6.5-7.5 $\mu \mathrm{m}$, av. $12.5 \times$ $6.6 \mu \mathrm{m}, \mathrm{Qav}=1.881, \mathrm{n}=6$.

Nemania serpens (Pers.) Gray, Nat. Arr. Brit. Pl. (London) 1: 516, 1821, Xylariaceae, found in plot Csörötnek 4 (I), Felsőszölnök 1, 3 (I) and Magyarlak (I), in stand type 1 and 3, on decaying wood of Quercus petraea and Fagus sylvatica.

Neobulgaria pura (Pers.) Petr., Annls Mycol. 19(1-2): 45, 1921, Helotiaceae, found in plot Szakonyfalu 2 (I), in stand type 2, on dead wood of broadleaved trees.

Neolentinus schaefferi (Weinm.) Redhead \& Ginns, Trans. Mycol. Soc. Japan 26(3): 357, 1985, Gloeophyllaceae, found in plot Szalafó 2 (I), in stand type 3, on decaying wood of Quercus petraea. 
Orbilia sarraziniana* Boud., Revue Mycol., (Toulouse) 7: 221, 1885, Orbiliaceae, found in plot Kétvölgy 2 (I) and Szentgotthárd 1 (I), in stand type 2 and 4, on dead wood of broadleaved trees.

Orbilia xanthostigma (Fr.) Fr., Summa veg. Scand., Section Post. (Stockholm): 357, 1849, Orbiliaceae, found in plot Felsőszölnök 2 (I), in stand type 1, on decaying wood of Fagus sylvatica.

Otidea alutacea (Pers.) Massee, Brit. Fung.-Fl. (London) 4: 446, 1895, Pyronemataceae, found in plot Felsöszölnök 3 (III), Kétvölgy 1 (III), Öriszentpéter 3 (III), Szalafö 3 (III) and Szentgotthárd 4 (III), in stand type 1, 3, 4 and 6, on soil; mainly among leaf, sometimes among mixed (needle and leaf) litter.

Otidea bufonia (Pers.) Boud., Hist. Class. Discom. Eur. (Paris): 52, 1907, Pyronemataceae, found in plot Apátistvánfalva (III), Szalafö 2, 7 (III) and Szentgotthárd 4 (III), in stand type 3, 4 and 6, on soil; mainly on mixed (needle and leaf), sometimes on leaf litter.

Otidea fuckelii* M. Carbone \& Van Vooren, Riv. Micol. 52(4): 322, 2010, Pyronemataceae, found in plot Felsőszölnök 2 (III), in stand type 1, on soil; mainly among leaf, sometimes among mixed (needle and leaf) litter. Specimen examined: ORS-ERDO 147-62-1 (October 16, 2010). Spores 8.6-12.9 × 4.7-6.5 $\mu \mathrm{m}$, av. $10.8 \times 5.9 \mu \mathrm{m}$, Qav $=1.846, \mathrm{n}=10$; paraphyses slightly curved.

Otidea grandis* (Pers.) Arnould, Bull. Soc. Mycol. Fr. 9: 111, 1893, Pyronemataceae, found in plot Öriszentpéter 3 (III), in stand type 3, on soil among leaf litter. Specimen examined: ORS-ERDO 125-36-5 (September 19, 2010). Spores 15.1-17.2 × 8.2-9.7 $\mu \mathrm{m}$, av. $16.1 \times 8.8$ $\mu \mathrm{m}, \mathrm{Qav}=1.837, \mathrm{n}=9$; paraphyses curved, $4.3 \mu \mathrm{m}$ wide, diameter of curves $10.8 \mu \mathrm{m}$.

Otidea onotica (Pers.) Fuckel, Jb. Nassau. Ver. Naturk. 23-24: 330, 1870, Pyronemataceae, found in plot Csörötnek 3, 5, 6 (III), Kétvölgy 1 (III), Orfalu 1 (III), Öriszentpéter 3 (III), Szakonyfalu 1, 2 (III), Szalafó 2, 5 (III) and Szentgotthárd 2 (III), in stand type 1-4 and 6, on soil; mainly among leaf, sometimes among mixed (needle and leaf) litter.

Otidea cf. propinquata (P. Karst.) Harmaja, Karstenia 15: 32, 1976, Pyronemataceae, found in plot Csörötnek 1 (II), in stand type 1, on decaying wood of Carpinus betulus.

Oxyporus latemarginatus (Durieu \& Mont.) Donk, Persoonia 4(3): 342, 1966, Schizoporaceae, found in plot Csörötnek 2 (I), Magyarlak (I) and Öriszentpéter 1 (I-II), in stand type 2, 3 and 6 , on dead wood of broadleaved trees.

Oxyporus cf. obducens (Pers.) Donk, Meddn. Bot. Mus. Herb. Rijhs. Universit. Utrecht. 9: 202, 1933, Schizoporaceae, found in plot Öriszentpéter 3 (III), in stand type 3, on decaying wood of Quercus petraea.

Oxyporus populinus (Schumach.) Donk, Meddn. Bot. Mus. Herb. Rijhs. Universit. Utrecht. 9: 204, 1933, Schizoporaceae, found in plot Apátistvánfalva (II), in stand type 6, on decaying wood of Quercus rubra.

Panellus stipticus (Bull.) P. Karst., Bidr. Känn. Finl. Nat. Folk 32: 96, 1879, Mycenaceae, found in plot Alsószölnök 1 (I), Csörötnek 6 (III), Felsőszölnök 1 (III), 3 (I, III), Kétvölgy 2 (III), Orfalu 1 (I), 2 (I, III), Szakonyfalu 1 (III), Szalafö 2 (III), 3 (I, III) and Szentgotthárd 2, 4 (III), in stand type 1-4 and 6, on dead wood of broadleaved trees.

Paxillus involutus (Batsch) Fr., Epicr. Syst. Mycol. (Upsaliae): 317, 1838, Paxillaceae, found in plot Csörötnek 1, 3, 5 (III), Öriszentpéter 2, 4 (III), Szakonyfalu 1 (III), Szalafö 2 (III) and Szentgotthárd 2 (III), in stand type 1-3 and 6, mainly on mixed (needle and leaf), sometimes on leaf litter.

Pezicula carpinea (Pers.) Tul. \& C. Tul. ex Fuckel, Jb. Nassau. Ver. Naturk. 23-24: 279, 1870, Dermateaceae, found in plot Csörötnek 1 (I), in stand type 1, on living Carpinus betulus trees.

Peziza cf. arvernensis Roze \& Boud., Bull. Soc. Bot. Fr. 26(suppl.): LXXVI, 1879, Pezizaceae, found in plot Csörötnek 1 (III), in stand type 1, on leaf litter.

Peziza badia Pers., Observ. Mycol. (Lipsiae) 2: 78, 1800, Pezizaceae, found in plot Csörötnek 1 (II), in stand type 1, on leaf litter. 
Peziza micropus Pers., Icon. Desc. Fung. Min. Cognit. (Leipzig) 2: 30, 1800, Pezizaceae, found in plot Csörötnek 1 (II), Kétvölgy 2 (III), Szakonyfalu 2 (III) and Szalafö 4 (III), in stand type 1,2 and 6 , on dead wood and litter of broadleaved trees.

Peziza phyllogena Cooke, Mycographia, seu Icones Fungorum 1(4): 148, 1877, Pezizaceae, found in plot Öriszentpéter 2 (II), in stand type 6, on soil among mixed (needle and leaf) litter.

Peziza saniosa Schrad., J. Bot. (Schrader) 2(1): 64, 1799, Pezizaceae, found in plot Alsószölnök 2 (III) and Szalafö 2 (III), in stand type 3 and 5, on soil among needle or leaf litter.

Peziza succosa Berk., Ann. Mag. Nat. Hist., ser. 1, 6: 358, 1841, Pezizaceae, found in plot Öriszentpéter 3 (III), in stand type 3, on soil among leaf litter.

Phaeolus schweinitzii (Fr.) Pat., Essai Tax. Hyménomyc. (Lons-le-Saunier): 86, 1900, Fomitopsidaceae, found in plot Öriszentpéter 4 (III), in stand type 6, on needle litter.

Phaeomarasmius erinaceus (Fr.) Scherff. ex Romagn., Revue Mycol. (Paris) 2(5): 195, 1937, Tubariaceae, found in plot Csörötnek 1 (I, III), in stand type 1, on decaying wood of Carpinus betulus.

Phallus impudicus L., Sp. Pl. 2: 1179, 1753, Phallaceae, found in plot Csörötnek 1 (I-III), 5 (I) and Szentgotthárd 3 (I), in stand type 1 and 2, on soil among leaf litter.

Phellinidium ferrugineofuscum* (P. Karst.) Fiasson \& Niemelä, Karstenia 24: 26, 1984, Hymenochaetaceae, found in plot Apátistvánfalva (I) and Szalafó 4 (I), in stand type 6, on decaying wood of Pinus sylvestris. Specimen examined: ORS-ERDO 10/11 (August 2, 2009). Spores 3.6-4.5 × 1.8-2.1 $\mu \mathrm{m}$, cylindrical; seta straight, 45.0-54.0 × $7.2 \mu \mathrm{m}$.

Phellinus pomaceus (Pers.) Maire, Mus. Barcin. Scient. Nat. Op., ser. Bot. 37, 1933, Hymenochaetaceae, found in plot Öriszentpéter 3 (III), in stand type 3, on decaying wood of Prunus avium.

Phellinus tremulae (Bondartsev) Bondartsev \& P.N. Borisov, The Polyporaceae of the European USSR and Caucasia, 358, 1953, Hymenochaetaceae, found in plot Alsószölnök 2 (I, II), in stand type 5, on decaying wood of Populus tremula.

Phellinus viticola (Schwein.) Donk, Persoonia 4(3): 342, 1966, Hymenochaetaceae, found in plot Alsószölnök 2 (I, III), Csörötnek 6 (I, II), Szakonyfalu 1 (I, III), 2 (I, II) and Szalafö 4, 7 (III), in stand type 1, 2 and 4-6, on dead wood of conifers.

Phellodon melaleucus (Sw. ex Fr.) P. Karst., Revue Mycol. (Toulouse) 3(9): 19, 1881, Bankeraceae, found in plot Orfalu 2 (III), in stand type 4, on leaf litter.

Phlebia livida (Pers.) Bres., Atti Acad. Agiato Rovereto 3: 105, 1897, Meruliaceae, found in plot Csörötnek 1 (III), Felsőszölnök 2 (I) and Szentgotthárd 2 (II), in stand type 1 and 3, on decaying wood of Fagus sylvatica and Carpinus betulus.

Phlebia radiata Fr., Syst. Mycol. (Lundae) 1: 427, 1821, Meruliaceae, found in plot Csörötnek 1 (II), 3 (I), Öriszentpéter 1 (I), 3 (III) and Szentgotthárd 3 (II), in stand type 1-3 and 6, on dead wood of broadleaved trees.

Phlebia rufa (Pers.) M.P. Christ., Dansk Bot. Ark. 19(2): 164, 1960, Meruliaceae, found in plot Alsószölnök 1 (II), Csörötnek 1 (I, III), 3, 4 (II), Orfalu 2 (I), Öriszentpéter 3, 4 (II), 4 (III), Szalafó 1 (I) and 5-7 (II), in stand type 1-4 and 6, on dead wood of broadleaved trees.

Phlebia tremellosa (Schrad.) Nakasone \& Burds., Mycotaxon 21: 245, 1984, Meruliaceae, found in plot Csörötnek 1 (III), Kétvölgy 2 (III) and Szalafö 3 (III), in stand type 1, 2 and 4, on decaying wood of Carpinus betulus.

Phlebiella vaga (Fr.) P. Karst., Hedwigia 29: 271, 1890, Meruliaceae, found in plot Alsószölnök 1 (III), in stand type 6, on decaying wood of Pinus sylvestris.

Phloeomana speirea (Fr.) Redhead, Index Fungorum, 15: 2, 2013, Porotheleaceae, found in plot Öriszentpéter 4 (III) and Szalafó 2 (III), in stand type 3 and 6, on dead wood and litter of broadleaved and coniferous trees.

Pholiota flammans (Batsch) P. Kumm., Führ. Pilzk. (Zwickau): 84, 1871, Strophariaceae, found in plot Alsószölnök 2 (I), Öriszentpéter 2 (III) and Szalafö 7 (III), in stand type 4-6, on dead wood of conifers. 
Pholiota gummosa (Lasch) Singer, Lilloa 22: 517, 1951, Strophariaceae, found in plot Csörötnek 1 (III), in stand type 1 , on leaf litter.

Pholiota jahnii Tjall.-Beuk. \& Bas, Persoonia 13(1): 77, 1986, Strophariaceae, found in plot Felsőszölnök 3 (III), in stand type 1, on decaying wood of Fagus sylvatica.

Pholiota lenta (Pers.) Singer, Lilloa 22: 516, 1951, Strophariaceae, found in plot Csörötnek 4 (III), Felsőszölnök 2, 3 (III), Kétvölgy 1 (III), Magyarlak (III), Rábagyarmat (III), Szalafö 3 (III) and Szentgotthárd 1 (III), in stand type 1, 3 and 4, on leaf litter.

Pholiota scamba (Fr.) M.M. Moser, Persoonia 13(1): 81, 1986, Strophariaceae, found in plot Szalafö 1 (III), in stand type 6, on decaying wood of Pinus sylvestris.

Pholiota spumosa (Fr.) Singer, Lilloa 22: 517, 1951, Strophariaceae, found in plot Felsőszölnök 3 (III), in stand type 1, on leaf litter.

Pholiotina brunnea (Watling) Singer, Beih. Sydowia 7: 79, 1973, Bolbitiaceae, found in plot Kétvölgy 2 (III), Orfalu 2 (I) and Szakonyfalu 2 (I), in stand type 2 and 4, on leaf litter.

Physisporinus vitreus (Pers.) P. Karst., Bidr. Känn. Finl. Nat. Folk 48: 324, 1889, Meripilaceae, found in plot Csörötnek 1 (II, III) and Szentgotthárd 1 (I), in stand type 1 and 4, on dead wood of broadleaved and coniferous trees.

Piptoporus betulinus (Bull.) P. Karst., Revue Mycol. (Toulouse) 3(11): 9, 1881, Fomitopsidaceae, found in plot Alsószölnök 2 (I), Szakonyfalu 1 (I), Szalafö 1 (I, III), 3 (I) and 4 (II, III), in stand type 1 and 4-6, on decaying wood of Betula pendula.

Pleurotus pulmonarius (Fr.) Quél., Mém. Soc. Émul. Montbéliard, sér. 2, 5: 113, 1872, Pleurotaceae, found in plot Szakonyfalu 1 (III), in stand type 1, on decaying wood of Fagus sylvatica.

Plicaturopsis crispa (Pers.) D.A. Reid, Persoonia 3(1): 150, 1964, incertae sedis, found in plot Alsószölnök 2 (III), Apátistvánfalva (III), Felsőszölnök 2 (III), Kétvölgy 1, 2 (III), Orfalu 1 (III), Öriszentpéter 3 (III), Szakonyfalu 1 (I, III) and 2 (III), in stand type 1-3, 5 and 6, on dead wood of broadleaved trees.

Pluteus cervinus (Schaeff.) P. Kumm., Führ. Pilzk. (Zwickau): 99, 1871, Pluteaceae, found in plot Csörötnek 1 (II, III), 3, 4 (III), 5 (II, III), Kétvölgy 2 (I, III), Magyarlak (II), Öriszentpéter 3 (II), Rábagyarmat (III), Szalafö 2 (III), 4 (II), 7 (III), Szentgotthárd 1 (I) and 4 (III), in stand type 1-4 and 6, on dead wood of broadleaved trees.

Pluteus exiguus* (Pat.) Sacc., Syll. Fung. (Abellini) 5: 671, 1887, Pluteaceae, found in plot Szalafó 5 (III), in stand type 4, on decaying wood of Quercus petraea. Specimen examined: ORSERDO 129-43-1 (November 4, 2010). Spores 4.7-6.5 × 4.3-6.5 $\mu \mathrm{m}$, av. $6.0 \times 5.0 \mu \mathrm{m}$, Qav $=1.196, \mathrm{n}=10$; pileipellis trichoderm; cheilocystidia mucronate.

Pluteus leoninus (Schaeff.) P. Kumm., Führ. Pilzk. (Zwickau): 98, 1871, Pluteaceae, found in plot Alsószölnök 2 (I) and Öriszentpéter 3 (III), in stand type 3 and 5, on dead wood of broadleaved and coniferous trees.

Pluteus nanus (Pers.) P. Kumm., Führ. Pilzk. (Zwickau): 98, 1871, Pluteaceae, found in plot Csörötnek 1 (III), in stand type 1, on decaying wood of Fagus sylvatica.

Pluteus pellitus (Pers.) P. Kumm., Führ. Pilzk. (Zwickau): 98, 1871, Pluteaceae, found in plot Szentgotthárd 2 (I), in stand type 3, on decaying wood of Quercus petraea.

Pluteus podospileus Sacc. \& Cub., Syll. Fung. (Abellini) 5: 672, 1887, Pluteaceae, found in plot Öriszentpéter 4 (III) and Szalafö 2 (III), in stand type 3 and 6, on decaying wood of Quercus petraea.

Pluteus romellii (Britzelm.) Sacc., Syll. Fung. (Abellini) 11: 44, 1895, Pluteaceae, found in plot Öriszentpéter 3 (III), in stand type 3, on leaf litter.

Pluteus salicinus (Pers.) P. Kumm., Führ. Pilzk. (Zwickau): 99, 1871, Pluteaceae, found in plot Csörötnek 1 (III), in stand type 1, on decaying wood of Carpinus betulus.

Pluteus satur Kühner \& Romagn., Bull. Soc. Mycol. Fr. 72: 182, 1956, Pluteaceae, found in plot Szalafó 1 (III), in stand type 6, on decaying wood of Betula pendula. 
Pluteus semibulbosus (Lasch) Quél., Hyménomycètes (Alençon): 395, 1876, Pluteaceae, found in plot Csörötnek 1 (II), Öriszentpéter 4 (II), Szakonyfalu 1 (III), Szalafö 1 (I) and 2 (II), in stand type 1, 3 and 6, on dead wood of broadleaved trees.

Pluteus thomsonii (Berk. \& Broome) Dennis, Trans. Br. Mycol. Soc. 31(3-4): 206, 1948, Pluteaceae, found in plot Csörötnek 6 (II) and Öriszentpéter 3 (III), in stand type 3 and 4, on decaying wood of Quercus petraea.

Polyporus alveolaris (DC.) Bondartsev \& Singer, Annls Mycol. 39(1): 58, 1941, Polyporaceae, found in plot Alsószölnök 2 (I), Apátistvánfalva (I), Csörötnek 1, 2 (I), Szakonyfalu 1 (IIII), 2 (I, III), Szalafó 4 (I, III) and Szentgotthárd 4 (III), in stand type 1, 2, 5 and 6, on decaying wood of Fagus sylvatica and Carpinus betulus.

Polyporus arcularius (Batsch) Fr., Syst. Mycol. (Lundae) 1: 342, 1821, Polyporaceae, found in plot Csörötnek 5 (II), Szakonyfalu 1 (III) and Szentgotthárd 4 (III), in stand type 1 and 6, on decaying wood of Fagus sylvatica.

Polyporus brumalis (Pers.) Fr., Observ. Mycol. (Havniae) 2: 255, 1818, Polyporaceae, found in plot Csörötnek 4-6 (III) and Felsöszölnök 1 (III), in stand type 1, 3 and 4, on decaying wood of Fagus sylvatica and Quercus petraea.

Polyporus ciliatus Fr., Observ. Mycol. (Havniae) 1: 123, 1815, Polyporaceae, found in plot Alsószölnök 1 (III), Csörötnek 1, 5 (II), Orfalu 1 (I), Rábagyarmat (I), Rábagyarmat (II) and Szalafö 1 (II), in stand type 1, 3 and 6, on decaying wood of Fagus sylvatica and Quercus petraea.

Polyporus tuberaster (Jacq. ex Pers.) Fr., Syst. Mycol. (Lundae) 1: 347, 1821, Polyporaceae, found in plot Szakonyfalu 2 (II), Szalafó 5 (I) and Szentgotthárd 2 (II), in stand type 2-4, on decaying wood of Fagus sylvatica and Quercus petraea.

Polyporus varius (Pers.) Fr., Syst. Mycol. (Lundae) 1: 352, 1821, Polyporaceae, found in plot Alsószölnök 2 (I), Apátistvánfalva (I), Csörötnek 1 (I, III), Felsőszölnök 1, 2 (I, III), 3 (III), Orfalu 2 (I), Öriszentpéter 3 (III), Szakonyfalu 1 (I, III), 2 (I), Szalafö 4 (III), 5 (I, III), 6 (III) and Szentgotthárd 4 (I, III), in stand type 1-6, on dead wood of broadleaved trees.

Porostereum spadiceum (Pers.) Hjortstam \& Ryvarden, Syn. Fung. (Oslo) 4: 51, 1990, Phanerochaetaceae, found in plot Csörötnek 2 (I, III) and Felsöszölnök 3 (I, III), in stand type 1 and 2, on decaying wood of Fagus sylvatica.

Porotheleum fimbriatum* (Pers.) Fr., Observ. Mycol. (Havniae) 2: 272, 1818, Meripilaceae, found in plot Apátistvánfalva (I), Felsöszölnök 2 (I), Kétvölgy 1 (III) and 2 (I), in stand type 1, 2 and 6, on decaying wood of Fagus sylvatica and Quercus petraea. Specimen examined: ORS-ERDO 46/18 (August 8, 2009). Spores 4.3-4.7 × 2.2-3.0 $\mu \mathrm{m}$, av. $4.4 \times 2.5 \mu \mathrm{m}$, Qav $=$ $1.759, \mathrm{n}=5$, short cylindrical to ellipsoid; septa with clamps; cystidia absent.

Postia caesia (Schrad.) P. Karst., Revue Mycol. (Toulouse) 3(9): 19, 1881, Fomitopsidaceae, found in plot Csörötnek 6 (III), Öriszentpéter 1, 2 (III) and Szakonyfalu 1, 2 (III), in stand type 1, 2, 4 and 6, on dead wood of conifers.

Postia fragilis (Fr.) Jülich, Persoonia 11(4): 423, 1982, Fomitopsidaceae, found in plot Csörötnek 6 (III), Szakonyfalu 1 (I) and 2 (III), in stand type 1, 2 and 4, on decaying wood of Pinus sylvestris.

Postia ptychogaster (F. Ludw.) Westerh., Nordic Jl. Bot. 16(2): 213, 1996, Fomitopsidaceae, found in plot Alsószölnök 2 (III) and Szakonyfalu 1 (III), in stand type 1 and 5, on dead wood of conifers.

Postia simanii (Pilát ex Pilát) Jülich, Persoonia 11(4): 423, 1982, Fomitopsidaceae, found in plot Felsőszölnök 1 (I), Szakonyfalu 1 (II) and 2 (I, II), in stand type 1 and 2, on decaying wood of Fagus sylvatica.

Postia stiptica (Pers.) Jülich, Persoonia 11(4): 424, 1982, Fomitopsidaceae, found in plot Csörötnek 2 (I), 3 (I, III), 6 (III), Felsőszölnök 3 (II, III), Kétvölgy 1 (III), Öriszentpéter 1 (III), 4 (I), Rábagyarmat (III), Szakonyfalu 2 (III), Szalafö 3 (II), 4 (I), 5 (II) and 7 (III), in stand type 1-4 and 6 , on dead wood of broadleaved and coniferous trees. 
Postia subcaesia (A. David) Jülich, Persoonia 11(4): 424, 1982, Fomitopsidaceae, found in plot Alsószölnök 1 (I), Csörötnek 1 (III), 3 (I, III), 4, 5 (III), Felsőszölnök 1, 2 (III), Kétvölgy 1 (III), Orfalu 1 (III), Öriszentpéter 2 (III), Rábagyarmat (III), Szakonyfalu 1, 2 (III), Szalafö 1 (III) and Szentgotthárd 4 (III), in stand type 1-3 and 6, on dead wood of broadleaved trees.

Postia tephroleuca (Fr.) Jülich, Persoonia 11(4): 424, 1982, Fomitopsidaceae, found in plot Csörötnek 1 (III), Szalafö 1, 2 (III) and Szentgotthárd 4 (III), in stand type 1, 3 and 6, on dead wood of broadleaved trees.

Psathyrella cernua* (Vahl) G. Hirsch, Wiss. Z. Friedrich Schiller-Univ. Jena, Math.-Nat. Reihe 33(6): 815, 1984, Psathyrellaceae, found in plot Csörötnek 5 (III) and Szentgotthárd 4 (III), in stand type 1 and 6, on leaf litter. Specimen examined: ORS-ERDO 136-35-3 (October 9, 2010). Spores 7.1-8.2 × 3.9-4.3 $\mu \mathrm{m}$, av. $7.6 \times 4.0 \mu \mathrm{m}, \mathrm{Qav}=1.902, \mathrm{n}=6$, light brown to yellowish brown, germ pore more or less absent; cheilocystidia 15.1-25.8 $\times 8.6-10.8 \mu \mathrm{m}$, lageniform with crystals, pleurocystidia $25.8-28.0 \times 8.6 \mu \mathrm{m}$, lageniform; pileipellis with isodiametrical, 15.1-32.3 $\mu \mathrm{m}$ wide elements and crystals.

Psathyrella cortinarioides* P.D. Orton, Trans. Br. Mycol. Soc. 43(2): 369, 1960, Psathyrellaceae, found in plot Szakonyfalu 2 (II), in stand type 2, on mixed (needle and leaf) litter. Specimen examined: ORS-ERDO 152-25-1b (May 29, 2010). Spores 6.9-8.8 × 4.4-5.0 $\mu \mathrm{m}$, av. $7.8 \times$ $4.7 \mu \mathrm{m}, \mathrm{Qav}=1.664, \mathrm{n}=30$, ellipsoid to phaseoliform, without germ pore; pleurocystidia 30.0-66.0 × 10.0-15.0 $\mu \mathrm{m}$, lageniform, cheilocystidia of two types: lageniform and clavate.

Psathyrella fagetophila* Örstadius \& Enderle, Beitr. Kenntn. Pilze Mitteleur. 10: 45, 1996, Psathyrellaceae, found in plot Kétvölgy 2 (II), in stand type 2, on mixed (needle and leaf) litter. Specimen examined: ORS-ERDO 113-42-1b (May 27, 2010). Spores 8.8-11.3 × 5.0$6.3 \mu \mathrm{m}$, av. $9.6 \times 5.3 \mu \mathrm{m}, \mathrm{Qav}=1.808, \mathrm{n}=30$, ellipsoid to slightly phaseoliform, with germ pore; basidia 4-spored; pleurocystidia 40.0-55.0 × 10.0-15.0 $\mu \mathrm{m}$, lageniform; cheilocystidia $16.0-19.0 \times 7.5-9.0 \mu \mathrm{m}$, clavate.

Psathyrella gossypina* (Bull.) A. Pearson \& Dennis, Trans. Br. Mycol. Soc. 31(3-4): 184, 1948, Psathyrellaceae, found in plot Csörötnek 6 (II) and Felsőszölnök 1 (II), in stand type 1 and 4, on leaf litter. Specimen examined: ORS-ERDO 138-51-1b (May 25, 2010). Spores 7.5$8.1 \times 4.4-5.0 \mu \mathrm{m}$, av. $7.8 \times 4.8 \mu \mathrm{m}, \mathrm{Qav}=1.645, \mathrm{n}=15$, ellipsoid to phaseoliform, with a small germ pore; basidia 4-spored; pleurocystidia lageniform, with central oil drop, sometimes branched, cheilocystidia clavate.

Psathyrella lutensis (Romagn.) Bon, Docums. Mycol. 12(46): 52, 1983, Psathyrellaceae, found in plot Felsőszölnök 2, 3 (III) and Kétvölgy 1 (III), in stand type 1, on leaf litter.

Psathyrella microrrhiza (Lasch) Konrad \& Maubl., Encyclop. Mycol. 14: 123, 1948, Psathyrellaceae, found in plot Csörötnek 1 (III), in stand type 1, mainly on leaf litter, sometimes on decaying wood of Carpinus betulus.

Psathyrella cf. olympiana A.H. Sm., Contr. Univ. Mich. Herb. 5: 36, 1941, Psathyrellaceae, found in plot Alsószölnök 2 (III), in stand type 5, on decaying wood of Betula pendula.

Psathyrella piluliformis (Bull.) P.D. Orton, Notes R. Bot. Gdn. Edinb. 29(1): 116, 1969, Psathyrellaceae, found in plot Csörötnek 4 (III), Kétvölgy 2 (III), Öriszentpéter 3 (III), Szakonyfalu 1 (III), Szalafő 2, 7 (III) and Szentgotthárd 1 (III), in stand type 1-4, on dead wood and litter of broadleaved trees.

Psathyrella prona (Fr.) Gillet, Hyménomycètes (Alençon): 618, 1878, Psathyrellaceae, found in plot Felsőszölnök 3 (III), in stand type 1, on leaf litter.

Psathyrella pygmaea (Bull.) Singer, Lilloa 22: 467, 1951, Psathyrellaceae, found in plot Alsószölnök 2 (III), Csörötnek 1, 5 (III), Felsőszölnök 2 (III), Kétvölgy 2 (III), Öriszentpéter 2, 4 (III), Szakonyfalu 1, 2 (III) and Szalafö 2 (III), in stand type 1-3, 5 and 6, on dead wood and litter of broadleaved trees.

Psathyrella spadiceogrisea (Schaeff.) Maire, Mém. Soc. Sci. Nat. Maroc. 45: 113, 1937, Psathyrellaceae, found in plot Csörötnek 1 (II), in stand type 1, on decaying wood of Fagus sylvatica. 
Pseudocraterellus undulatus (Pers.) Rauschert, Feddes Repert. Spec. Nov. Regni Veg. 98(11-12): 661, 1987, Cantharellaceae, found in plot Alsószölnök 1 (III), Apátistvánfalva (III), Csörötnek 1, 3, 5 (III), Felsőszölnök 1-3 (III), Kétvölgy 1, 2 (III), Orfalu 1, 2 (III), Öriszentpéter 3 (III), Rábagyarmat (III), Szakonyfalu 1, 2 (I, III), Szalafő 1-5, 7 (III) and Szentgotthárd 4 (III), in stand type 1-4 and 6, mainly on leaf, sometimes on mixed (needle and leaf) litter.

Pseudohydnum gelatinosum (Scop.) P. Karst., Not. Sällsk. Fauna et Fl. Fenn. Förh. 9: 374, 1868, incertae sedis, found in plot Alsószölnök 1 (I), 2 (I, III), Orfalu 1 (I, III), Öriszentpéter 2 (III), Szakonyfalu 1, 2 (I, III), Szalafö 4, 7 (III) and Szentgotthárd 1 (I, III), in stand type 1, 2 and 4-6, on decaying wood of Pinus sylvestris.

Pseudomerulius aureus* (Fr.) Jülich, Persoonia 10(3): 330, 1979, Tapinellaceae, found in plot Apátistvánfalva (I) and Szalafó 1 (I, III), in stand type 6, on decaying wood of Pinus sylvestris. Specimen examined: ORS-ERDO 7/13 (August 2, 2009). Spores 3.9-4.3 × 1.3$1.9 \mu \mathrm{m}$, av. $4.0 \times 1.8 \mu \mathrm{m}, \mathrm{Qav}=2.306 \mathrm{n}=6$, cylindrical, smooth-walled; hyphal system monomitic.

Ramaria apiculata* (Fr.) Donk, Biblthca Mycol. 21: 105, 1933, Gomphaceae, found in plot Alsószölnök 1 (III), Orfalu 1 (III) and Szakonyfalu 1 (III), in stand type 1 and 6, on decaying wood of Pinus sylvestris. Specimen examined: ORS-ERDO 151-56-1 (September 24, 2010). Spores 7.9-9.5 × 3.2-3.9 $\mu \mathrm{m}$, av. 8.6 × 3.8 $\mu \mathrm{m}$, Qav $=2.263, \mathrm{n}=10$, brown in $\mathrm{KOH}$, warty-bulgeous; rhizomorphs with rosette-like crystals.

Ramaria eumorpha (P. Karst.) Corner, Ann. Bot. Memoir 1: 575, 1950, Gomphaceae, found in plot Szalafö 1 (III), in stand type 6, on mixed (needle and leaf) litter.

Ramaria cf. fagetorum Maas Geest. ex Schild, Z. Mykol. 44(2): 174, 1978, Gomphaceae, found in plot Szakonyfalu 1 (III), in stand type 1, on mixed (needle and leaf) litter.

Ramaria cf. fennica var. fennica (P. Karst.) Ricken, Vadem. Pilzfr.: 264, 1920, Gomphaceae, found in plot Csörötnek 3 (III) and Szalafö 1 (III), in stand type 2 and 6, on mixed (needle and leaf) litter, sometimes on decaying wood of Pinus sylvestris.

Ramaria fennica var. fumigata (Peck) Schild, Z. Mykol. 61(2): 149, 1995, Gomphaceae, found in plot Felsőszölnök 3 (I) and Szakonyfalu 2 (III), in stand type 1 and 2, on mixed (needle and leaf) litter.

Ramaria flaccida (Fr.) Bourdot, Rev. Sci. du Bourb. 11: 235, 1898, Gomphaceae, found in plot Apátistvánfalva (I, III), Felsőszölnök 2 (III), Szalafő 3 (III) and Szentgotthárd 1 (III), in stand type 1, 4 and 6, on mixed (needle and leaf) litter.

Ramaria cf. flavescens (Schaeff.) R.H. Petersen, Am. J. Bot. 61(7): 740, 1974, Gomphaceae, found in plot Apátistvánfalva (III) and Szalafö 4 (III), in stand type 6, on mixed (needle and leaf) litter.

Ramaria formosa (Pers.) Quél., Fl. Mycol. France (Paris): 466, 1888, Gomphaceae, found in plot Kétvölgy 1 (I), in stand type 1 , on leaf litter.

Ramaria stricta (Pers.) Quél., Fl. Mycol. France (Paris): 464, 1888, Gomphaceae, found in plot Apátistvánfalva (III), Csörötnek 1, 3, 5, 6 (III), Felsőszölnök 1, 2 (III), Orfalu 1 (III), Öriszentpéter 1-3 (III), Szakonyfalu 1, 2 (III), Szalafö 2, 4 (III) and Szentgotthárd 4 (III), in stand type 1-4 and 6, on dead wood and litter of broadleaved and coniferous trees.

Resupinatus applicatus (Batsch) Gray, Nat. Arr. Brit. Pl. (London) 1: 617, 1821, Tricholomataceae, found in plot Alsószölnök 1 (I), Csörötnek 3 (III), Felsőszölnök 3 (I), Szalafö 2 (III) and Szentgotthárd 4 (I), in stand type 1-3 and 6, on dead wood of broadleaved and coniferous trees.

Resupinatus trichotis (Pers.) Singer, Persoonia 2(1): 48, 1961, Tricholomataceae, found in plot Öriszentpéter 2 (III), in stand type 6, on decaying wood of Quercus petraea.

Rhizopogon roseolus (Corda) Th. Fr., Svensk Bot. Tidskr. 3: 282, 1909, Rhizopogonaceae, found in plot Orfalu 2 (I) and 2 (III), in stand type 4, in soil.

Rhodocollybia butyracea (Bull.) Lennox, Mycotaxon 9: 218, 1979, Marasmiaceae, found in plot Alsószölnök 2 (III), Csörötnek 1, 3, 5, 6 (III), Felsőszölnök 2 (III), Orfalu 1 (III), 
Öriszentpéter 2, 4 (III), Szakonyfalu 1, 2 (III), Szalafö 1, 2 (III) and Szentgotthárd 1, 2, 4 (III), in stand type 1-6, mainly on mixed (needle and leaf), sometimes on leaf litter.

Rhodocollybia prolixa var. distorta (Fr.) Antonín, Halling \& Noordel., Mycotaxon 63: 365, 1997, Marasmiaceae, found in plot Orfalu 1 (II), in stand type 6, on decaying wood of Pinus sylvestris.

Rhodocybe gemina (Paulet) Kuyper \& Noordel., Persoonia 13(3): 379, 1987, Entolomataceae, found in plot Öriszentpéter 3, 4 (III), in stand type 3 and 6, mainly on mixed (needle and leaf), sometimes on leaf litter.

Rickenella fibula (Bull.) Raithelh., Metrodiana 4: 67, 1973, Repetobasidiaceae, found in plot Alsószölnök 2 (III), Csörötnek 1 (III), Öriszentpéter 4 (III), Rábagyarmat (III), Szakonyfalu 1, 2 (III) and Szalafo" 1, 2 (III), in stand type 1-3, 5 and 6, among mosses.

Rickenella swartzii (Fr.) Kuyper, Persoonia 12(2): 188, 1984, Repetobasidiaceae, found in plot Orfalu 1 (III), Öriszentpéter 4 (III), Szalafö 2 (III) and Szentgotthárd 4 (III), in stand type 3 and 6 , among mosses.

Rigidoporus sanguinolentus (Alb. \& Schwein.) Donk, Persoonia 4(3): 341, 1966, Meripilaceae, found in plot Szakonyfalu 1 (III), in stand type 1, on decaying wood of Pinus sylvestris.

Ripartites tricholoma (Alb. \& Schwein.) P. Karst., Bidr. Känn. Finl. Nat. Folk 32: 477, 1879, Tricholomataceae, found in plot Öriszentpéter 1, 4 (III) and Szalafö 4 (III), in stand type 6, on mixed (needle and leaf) litter.

Roridomyces roridus (Scop.) Rexer, Die Gattung Mycena s.l., Studien zu Ihrer Anatomie, Morphologie und Systematik (Tübingen): 132, 1994, Myceanaceae, found in plot Öriszentpéter 2, 4 (III), Szakonyfalu 2 (III) and Szalafö 1, 2 (III), in stand type 2, 3 and 6, mainly on mixed (needle and leaf), sometimes on leaf litter.

Rosellinia corticium (Schwein.) Sacc., Syll. Fung. (Abellini) 1: 253, 1882, Xylariaceae, found in plot Csörötnek 6 (I), in stand type 4, on decaying wood of Quercus petraea.

Rosellinia desmazieri (Berk. \& Broome) Sacc., Michelia 1(4): 371, 1878, Xylariaceae, found in plot Csörötnek 1 (I), in stand type 1, on decaying wood of Fagus sylvatica.

Russula acrifolia Romagn., Docums. Mycol. 26(104): 32, 1997, Russulaceae, found in plot Apátistvánfalva (I), Orfalu 1, 2 (I), Öriszentpéter 2 (I), Szakonyfalu 1 (I, III), 2 (I), Szalafö 2 (I), 3 (I, III), 5, 6 (I) and Szentgotthárd 1, 3, 4 (I), in stand type 1-4 and 6, mainly on mixed (needle and leaf), sometimes on leaf litter.

Russula aeruginea Lindblad, Monogr. Hymenomyc. Suec. (Upsaliae), 2(2): 198, 1863, Russulaceae, found in plot Orfalu 1 (III), in stand type 6, on mixed (needle and leaf) litter.

Russula amarissima Romagn. \& E.-J. Gilbert, Bull. Soc. Mycol. Fr. 59: 71, 1943, Russulaceae, found in plot Alsószölnök 2 (III), in stand type 5, on mixed (needle and leaf) litter.

Russula amoenolens Romagn., Bull. Mens. Soc. Linn. Lyon, 21: 111, 1952, Russulaceae, found in plot Alsószölnök 2 (I), Csörötnek 1 (III), Öriszentpéter 4 (I, III), Rábagyarmat (III) and Szalafö 1 (I), in stand type 1, 3, 5 and 6, mainly on mixed (needle and leaf), sometimes on leaf litter.

Russula aquosa Leclair, Bull. Trimest. Soc. Mycol. Fr. 48: 303, 1932, Russulaceae, found in plot Alsószölnök 1 (III), Szakonyfalu 1 (I), Szalafö 1 (III) and 2 (I), in stand type 1, 3 and 6, on mixed (needle and leaf) litter.

Russula caerulea Fr., Epicr. Syst. Mycol. (Upsaliae): 353, 1838, Russulaceae, found in plot Apátistvánfalva (III), Orfalu 1 (III), Öriszentpéter 2 (I), 2 (III), Szalafö 4 (I, III) and Szentgotthárd 1 (III), in stand type 4 and 6, mainly on mixed (needle and leaf), sometimes on needle litter.

Russula chloroides (Krombh.) Bres., Fung. Trident. 2(14): 89, 1900, Russulaceae, found in plot Szakonyfalu 2 (I) and Szalafö 5, 7 (I), in stand type 2 and 4, mainly on leaf, sometimes on mixed (needle and leaf) litter.

Russula clavipes Velen., České Houby 1: 143, 1920, Russulaceae, found in plot Szalafö 1 (III), in stand type 6, on mixed (needle and leaf) litter. 
Russula cremeoavellanea* Singer, Revue Mycol. (Paris) 1: 288, 1936, Russulaceae, found in plot Szalafo' 1 (III), in stand type 6, on mixed (needle and leaf) litter. Specimen examined: ORSERDO 98-53-2b (September 21, 2010). Spores 7.2-8.1 × 5.6-6.9 $\mu \mathrm{m}$, av. $7.8 \times 6.2 \mu \mathrm{m}$, Qav $=1.262, \mathrm{n}=11$, strongly isolated verrucose to spiny; pileipellis with incrusted primordial hyphae.

Russula cyanoxantha (Schaeff.) Fr., Monogr. Hymenomyc. Suec. (Upsaliae), 2(2): 194, 1863, Russulaceae, found in plot Alsószölnök 1 (I), 2 (I, III), Apátistvánfalva (I, III), Csörötnek 1 (I), 2 (I, III), 3, 4, 5 (I), 6 (III), Felsőszölnök 1 (I), 2, 3 (I, III), Kétvölgy 1, 2 (I), Orfalu 1 (I, III), 2 (I, II), Öriszentpéter 1-4 (I, III), Rábagyarmat (I), Szakonyfalu 1, 2 (I, III), Szalafő 1 (I), 2, 3 (I, III), 4-6 (I), 7 (I, III), Szentgotthárd 1, 2 (I), 3 (I, III) and 4 (I), in stand type 1-6, mainly on mixed (needle and leaf), sometimes on leaf litter.

Russula densifolia Secr. ex Gillet, Hyménomycètes (Alençon): 231, 1876, Russulaceae, found in plot Alsószölnök 2 (III), Kétvölgy 2 (I), Orfalu 2 (I), Öriszentpéter 2 (III), Szalafö 1, 2 (III) and Szentgotthárd 4 (III), in stand type 2-6, mainly on mixed (needle and leaf), sometimes on leaf litter.

Russula emetica (Schaeff.) Pers., Observ. Mycol. (Lipsiae) 1: 100, 1796, Russulaceae, found in plot Alsószölnök 1 (I, III), Apátistvánfalva (III), Csörötnek 3-5 (III), Felsőszölnök 1-3 (III), Kétvölgy 1, 2 (III), Magyarlak (I), Orfalu 1 (III), Rábagyarmat (III), Szakonyfalu 1, 2 (III), Szalafö 1-3 (III), 4 (I, III), 5-7 (III) and Szentgotthárd 1, 4 (III), in stand type 1-4 and 6, mainly on mixed (needle and leaf), sometimes on leaf litter.

Russula farinipes Romell, Mém. Soc. Linn. Normandie 9: 239, 1893, Russulaceae, found in plot Felsőszölnök 2 (III), in stand type 1, on leaf litter.

Russula fellea (Fr.) Fr., Epicr. Syst. Mycol. (Upsaliae): 354, 1838, Russulaceae, found in plot Alsószölnök 1 (I, III), Apátistvánfalva (III), Csörötnek 2-6 (III), Felsőszölnök 1 (III), 2 (I, III), 3 (III), Kétvölgy 1 (III), Orfalu 1 (III), Öriszentpéter 1 (III), Rábagyarmat (III), Szakonyfalu 1, 2 (III), Szalafö 1 (I), 4, 6, 7 (III), Szentgotthárd 1 (I, III) and 2, 4 (III), in stand type 1-4 and 6, mainly on mixed (needle and leaf), sometimes on leaf litter.

Russula foetens Pers., Observ. Mycol. (Lipsiae) 1: 102, 1796, Russulaceae, found in plot Kétvölgy 1 (III) and Orfalu 1 (III), in stand type 1 and 6, on mixed (needle and leaf) litter.

Russula fragilis Fr., Epicr. Syst. Mycol. (Upsaliae): 359, 1838, Russulaceae, found in plot Alsószölnök 1 (III), Apátistvánfalva (III), Csörötnek 4, 6 (III), Orfalu 1, 2 (III), Öriszentpéter 2, 3 (III), Rábagyarmat (III), Szakonyfalu 1 (III), Szalafö 1, 3-7 (III) and Szentgotthárd 1-4 (III), in stand type 1-4 and 6, mainly on mixed (needle and leaf), sometimes on leaf litter.

Russula fragrantissima Romagn., Russules d'Europe Afr. Nord: 350, 1967, Russulaceae, found in plot Alsószölnök 2 (I) and Felsőszölnök 2 (I), in stand type 1 and 5, on mixed (needle and leaf) litter.

Russula grata Britzelm., Ber. Naturhist. Augsburg 9: 239, 1898, Russulaceae, found in plot Alsószölnök 2 (I), Felsőszölnök 2 (I), Kétvölgy 2 (III), Öriszentpéter 1, 3 (I), Szakonyfalu 1 (I, III), Szalafö 1 (I, III), 3, 5-7 (I) and Szentgotthárd 1, 4 (I), in stand type 1-6, mainly on leaf, sometimes on mixed (needle and leaf) litter.

Russula graveolens Romell, Bot. Cbl. 54(3): 100, 1885, Russulaceae, found in plot Felsőszölnök 2 (I) and Szalafó 1 (III), in stand type 1 and 6, mainly on mixed (needle and leaf), sometimes on leaf litter.

Russula grisea Fr., Epicr. Syst. Mycol. (Upsaliae): 361, 1838, Russulaceae, found in plot Csörötnek 1 (II, III), in stand type 1, on leaf litter.

Russula heterophylla (Fr.) Fr., Epicr. Syst. Mycol. (Upsaliae): 352, 1838, Russulaceae, found in plot Csörötnek 3, 5 (I), Kétvölgy 2 (I), Orfalu 1, 2 (I), Öriszentpéter 2-4 (I), Szalafö 2, 5-7 (I) and Szentgotthárd 2, 3 (I), in stand type 1-4 and 6, mainly on leaf, sometimes on mixed (needle and leaf) litter.

Russula illota Romagn., Bull. Mens. Soc. Linn. Lyon, 23: 175, 1954, Russulaceae, found in plot Felsőszölnök 2 (I), Kétvölgy 2 (I), Öriszentpéter 2 (I, III), 3 (I), Szakonyfalu 1 (I, III), 2 (I), 
Szalafö 2 (III), 3 (I) and Szentgotthárd 1 (I), in stand type 1-4 and 6, mainly on leaf, sometimes on mixed (needle and leaf) litter.

Russula lilacea Quél., Bull. Soc. Bot. Fr. 23: 330, 1877, Russulaceae, found in plot Szalafö 7 (I), in stand type 4 , on leaf litter.

Russula lutensis* Romagn. \& Le Gal, Bull. Soc. Mycol. Fr. 56: 66, 1940, Russulaceae, found in plot Szakonyfalu 1 (III), in stand type 1, on mixed (needle and leaf) litter. Specimen examined: ORS-ERDO 151-11-1b (September 24, 2010). Spores 7.1-8.8 × 5.6-6.9 $\mu \mathrm{m}$, av. $7.9 \times 6.2 \mu \mathrm{m}, \mathrm{Qav}=1.290, \mathrm{n}=35$, subglobose to broadly ellipsoid, isolated verrucose (with coarse warts), amyloid.

Russula mairei Singer, Bull. Soc. Mycol. Fr. 45: 103, 1929, Russulaceae, found in plot Apátistvánfalva (III), Felsőszölnök 2, 3 (III), Kétvölgy 1 (III), Szalafő 1 (I, III) and Szentgotthárd 4 (I, III), in stand type 1 and 6, mainly on mixed (needle and leaf), sometimes on leaf litter.

Russula minutula Velen., České Houby 1: 133, 1920, Russulaceae, found in plot Felsőszölnök 3 (I), in stand type 1, on leaf litter.

Russula nigricans Fr., Epicr. Syst. Mycol. (Upsaliae): 350, 1838, Russulaceae, found in plot Alsószölnök 2 (I, III), Csörötnek 2, 3 (I, III), 4 (III), 5, 6 (I, III), Kétvölgy 1 (I), Magyarlak (I, III), Orfalu 1, 2 (I, III), Öriszentpéter 1 (I, III), 2 (I), 3 (I, III), 4 (III), Rábagyarmat (III), Szakonyfalu 1 (I), Szalafö 5 (III) and Szentgotthárd 1-3 (I, III), in stand type 1-6, mainly on leaf, sometimes on mixed (needle and leaf) litter.

Russula nitida (Pers.) Fr., Epicr. Syst. Mycol. (Upsaliae): 361, 1838, Russulaceae, found in plot Szalafö 1 (III), in stand type 6, on mixed (needle and leaf) litter.

Russula ochroleuca Pers., Observ. Mycol. (Lipsiae) 1: 102, 1796, Russulaceae, found in plot Alsószölnök 2 (I, III), Apátistvánfalva (III), Csörötnek 3, 5 (III), Kétvölgy 1, 2 (III), Orfalu 1 (I, III), Öriszentpéter 3 (III), Szakonyfalu 1 (I, III), 2 (III), Szalafö 1 (III) and Szentgotthárd 1 (III), in stand type 1-6, mainly on mixed (needle and leaf), sometimes on leaf litter.

Russula odorata Romagn., Bull. Mens. Soc. Linn. Lyon 19: 76, 1950, Russulaceae, found in plot Öriszentpéter 3 (III), Szakonyfalu 1 (III) and Szalafö 1 (III), in stand type 1, 3 and 6, mainly on mixed (needle and leaf), sometimes on leaf litter.

Russula pectinatoides Peck, Bull. N.Y. St. Mus. 116: 43, 1907, Russulaceae, found in plot Alsószölnök 2 (I), Csörötnek 1 (III) and Öriszentpéter 3 (III), in stand type 1, 3 and 5, mainly on leaf, sometimes on mixed (needle and leaf) litter.

Russula pseudointegra Arnould \& Goris, Bull. Soc. Mycol. Fr. 23: 177, 1907, Russulaceae, found in plot Öriszentpéter 3 (III), in stand type 3, on leaf litter.

Russula puellaris Fr., Epicr. Syst. Mycol. (Upsaliae): 362, 1838, Russulaceae, found in plot Alsószölnök 1 (III) and Szentgotthárd 1 (III), in stand type 4 and 6, mainly on mixed (needle and leaf), sometimes on leaf litter.

Russula puellula Ebbesen, F.H. Møller \& Jul. Schäff., Annls Mycol. 35(2): 106, 1937, Russulaceae, found in plot Csörötnek 1 (III), Orfalu 2 (I) and Szalafö 1 (III), in stand type 1, 4 and 6, mainly on mixed (needle and leaf), sometimes on leaf litter.

Russula queletii Fr., Mém. Soc. Émul. Montbéliard, sér. 2, 5: 185, 1872, Russulaceae, found in plot Alsószölnök 2 (III), in stand type 5, on mixed (needle and leaf) litter.

Russula raoultii Quél., Compt. Rend. Assoc. Franç. Avancem. Sci. 14: 449, 1886, Russulaceae, found in plot Apátistvánfalva (III), Csörötnek 1 (III), Szakonyfalu 1 (III), 2 (I) and Szalafö 2 (III), in stand type 1-3 and 6, mainly on mixed (needle and leaf), sometimes on leaf litter.

Russula rhodella E.-J. Gilbert, Bull. Trimest. Soc. Mycol. Fr. 48: 111, 1932, Russulaceae, found in plot Szakonyfalu 1 (III), in stand type 1, mainly on mixed (needle and leaf), sometimes on leaf litter.

Russula sanguinea (Bull.) Fr., Epicr. Syst. Mycol. (Upsaliae): 351, 1838, Russulaceae, found in plot Szalafö 1, 3 (I) and 7 (III), in stand type 4 and 6, on mixed (needle and leaf) litter. 
Russula sardonia Fr., Epicr. Syst. Mycol. (Upsaliae): 353, 1838, Russulaceae, found in plot Apátistvánfalva (I, III), Csörötnek 5 (III), Orfalu 1, 2 (III), Szalafö 1, 3, 4 (III) and Szentgotthárd 4 (III), in stand type 1, 4 and 6, mainly on mixed (needle and leaf), sometimes on leaf litter.

Russula solaris Ferd. \& Winge, Meddr. Foren. Svampekundsk. Fremme 2: 9, 1924, Russulaceae, found in plot Csörötnek 1 (III), in stand type 1, on leaf litter.

Russula tinctipes* J. Blum ex Bon, Cryptog. Mycol. 7(4): 308, 1986, Russulaceae, found in plot Öriszentpéter 3 (I), in stand type 3, on leaf litter. Specimen examined: ORS-ERDO 1/11 (August 1, 2009). Spores 7.9-9.6 × 6.5-8.4 $\mu \mathrm{m}$, av. $8.6 \times 7.3 \mu \mathrm{m}$, Qav $=1.190, \mathrm{n}=15$, subglobose to ovoid, weakly but densely isolated verrucose to spiny with some connection, amyloid.

Russula torulosa Bres., Iconogr. Mycol. 9: tab. 433, 1929, Russulaceae, found in plot Szalafó 1 (III), in stand type 6, on mixed (needle and leaf) litter.

Russula undulata Velen., České Houby 1: 131, 1920, Russulaceae, found in plot Alsószölnök 1 (I, III), Csörötnek 1-4 (III), 5 (I, III), 6 (III), Magyarlak (III), Öriszentpéter 1 (III), 2,3 (I, III), Rábagyarmat (III), Szalafö 1 (I, III), 2 (III), 5 (I), 7 (I, III), Szentgotthárd 1, 2 (III) and 3 (I, III), in stand type 1-4 and 6, mainly on leaf, sometimes on mixed (needle and leaf) litter.

Russula vesca Fr., Anteckn. Sver. Ätl. Svamp.: 51, 1836, Russulaceae, found in plot Alsószölnök 1 (I, III), 2 (I), Csörötnek 3, 5, 6 (I), Felsőszölnök 3 (I), Kétvölgy 2 (I, III), Magyarlak (I), Orfalu 1, 2 (I), Öriszentpéter 3 (I), Szakonyfalu 1 (I, III), 2 (I), Szalafö 2 (III), 3, 5, 6 (I) and Szentgotthárd 1, 2, 4 (I), in stand type 1-6, mainly on leaf, sometimes on mixed (needle and leaf) litter.

Russula virescens (Schaeff.) Fr., Anteckn. Sver. Ätl. Svamp.: 50, 1836, Russulaceae, found in plot Felsőszölnök 3 (I), in stand type 1, on mixed (needle and leaf) litter.

Rutstroemia firma (Pers.) P. Karst., Bidr. Känn. Finl. Nat. Folk 19: 108, 1871, Rutstroemiaceae, found in plot Csörötnek 5 (III), Orfalu 1 (III) and Öriszentpéter 2, 3 (III), in stand type 1, 3 and 6 , on dead wood of broadleaved trees.

Sarcodon squamosus (Schaeff.) P. Karst., Hedwigia 28: 366, 1889, Bankeraceae, found in plot Alsószölnök 1 (III), in stand type 6, on mixed (needle and leaf) litter.

Schizophyllum commune Fr., Syst. Mycol. (Lundae) 1: 330, 1821, Schizophyllaceae, found in plot Csörötnek 1 (I, III), 6 (III), Felsőszölnök 1 (I, III), Kétvölgy 2 (III), Magyarlak (III), Orfalu 1 (II), Öriszentpéter 3, 4 (III), Rábagyarmat (I, III), Szakonyfalu 1 (III), 2 (II), Szalafö 1 (II), 2 (III), 7 (I, II) and Szentgotthárd 3 (III), in stand type 1-4 and 6, on dead wood of broadleaved trees.

Schizopora flavipora (Berk. \& M.A. Curtis ex Cooke) Ryvarden, Mycotaxon 23: 186, 1985, Schizoporaceae, found in plot Alsószölnök 2 (I), Apátistvánfalva (I), Csörötnek 1 (I-III), 2 (II, III), 3, 4, 6 (I, II), Felsőszölnök 1 (I, III), 2 (II), 3 (III), Kétvölgy 1, 2 (I), Magyarlak (I, III), Orfalu 2 (I, III), Öriszentpéter 1 (II, III), 2 (I, III), 3 (I-III), Rábagyarmat (II), Szakonyfalu 1 (I-III), 2 (I, III), Szalafó 1 (I), 2, 5 (III), 6 (II, III), 7 (II), Szentgotthárd 1 (I, II), 2 (II, III), 3 (I-III) and 4 (I, II), in stand type 1-6, on dead wood of broadleaved trees.

Schizopora paradoxa (Schrad.) Donk s.l., Persoonia 5(1): 76, 1967, Schizoporaceae, found in plot Alsószölnök 1 (II), 2 (I), Csörötnek 1 (I, II), 2 (I-III), 3, 4 (I, II), 5 (I, III), 6 (I, II), Felsőszölnök 3 (I, III), Kétvölgy 1 (I, III), Magyarlak (I-III), Orfalu 1 (I), 2 (I, III), Öriszentpéter 1, 2 (III), 3 (I-III), 4 (I), Rábagyarmat (I, II), Szakonyfalu 1 (III), 2 (I, II), Szalafö 1 (II), 2 (I-III), 3, 4 (I), 5 (I, III), 6 (I, II), 7 (III), Szentgotthárd 1, 2 (I-III), 3 (I, III) and 4 (II, III), in stand type 1-6, on dead wood of broadleaved trees.

Scleroderma areolatum Ehrenb., Sylv. Mycol. Berol. (Berlin) 15: 27, 1818, Sclerodermataceae, found in plot Csörötnek 1 (I, III), 5 (III), 6 (I), Orfalu 2 (I), Öriszentpéter 4 (I, III), Rábagyarmat (III) and Szentgotthárd 1 (III), in stand type 1, 3, 4 and 6, mainly on leaf, sometimes on mixed (needle and leaf) litter.

Scleroderma cepa Pers., Syn. Meth. Fung. (Göttingen) 1: 155, 1801, Sclerodermataceae, found in plot Csörötnek 1 (III), in stand type 1, on leaf litter. 
Scleroderma citrinum Pers., Syn. Meth. Fung. (Göttingen) 1: 153, 1801, Sclerodermataceae, found in plot Alsószölnök 1 (I, III) and Öriszentpéter 4 (I, III), in stand type 6, mainly on mixed (needle and leaf), sometimes on needle litter.

Sebacina incrustans (Pers.) Tul. \& C. Tul., Annls Sci. Nat., Bot., sér. 5, 15: 225, 1875, Sebacinaceae, found in plot Csörötnek 5 (III) and Szalafö 1 (III), in stand type 1 and 6, mainly on leaf, sometimes on mixed (needle and leaf) litter.

Simocybe centunculus (Fr.) Singer, Bidr. Känn. Finl. Nat. Folk 32: 420, 1879, Crepidotaceae, found in plot Apátistvánfalva (I), Csörötnek 1 (II, III), Öriszentpéter 3 (II, III), Szakonyfalu 1, 2 (I), Szalafö 1 (III), 2 (II, III) and Szentgotthárd 4 (III), in stand type 1, 2, 3 and 6, on dead wood of broadleaved trees.

Simocybe haustellaris (Fr.) Watling, Biblthca Mycol. 82: 39, 1981, Crepidotaceae, found in plot Orfalu 1 (I), in stand type 6, on decaying wood of Populus tremula.

Sistotrema confluens Pers., Neues Mag. Bot. 1: 108, 1794, Hydnaceae, found in plot Szakonyfalu 1 (III) and Szalafó 1 (III), in stand type 1 and 6, mainly on mixed (needle and leaf) litter, sometimes on dead wood of broadleaved trees.

Skeletocutis cf. alutacea (J. Lowe) Jean Keller, Persoonia 10(3): 353, 1979, Polyporaceae, found in plot Csörötnek 5 (I), in stand type 1, on decaying wood of Fagus sylvatica.

Skeletocutis amorpha (Fr.) Kotl. \& Pouzar, Česká Mykol. 12(2): 103, 1958, Polyporaceae, found in plot Apátistvánfalva (I), Szakonyfalu 2 (I) and Szalafö 7 (I), in stand type 2, 4 and 6, on decaying wood of Pinus sylvestris and Quercus petraea.

Skeletocutis carneogrisea* A. David, Naturaliste Can. 109(2): 245, 1982, Polyporaceae, found in plot Szalafó 7 (III), in stand type 4, on decaying wood of Pinus sylvestris. Specimen examined: ORS-ERDO 133-14-1 (October 23, 2010). Spores 3.9-4.3 × 1.1-1.7 $\mu \mathrm{m}$, av. 4.1 $\times 1.5 \mu \mathrm{m}, \mathrm{Qav}=2.639, \mathrm{n}=5$, allantoid; hyphal system dimitic, generative hyphae encrusted, with clamps, skeletal hyphae nonseptate, 2-5 $\mu \mathrm{m}$ wide.

Skeletocutis lenis (P. Karst.) Niemelä, Karstenia 31: 23, 1991, Polyporaceae, found in plot Öriszentpéter 1 (III) and Szalafö 3 (II), in stand type 4 and 6, on decaying wood of Pinus sylvestris and Quercus petraea.

Skeletocutis nivea (Jungh.) Jean Keller, Persoonia 10(3): 353, 1979, Polyporaceae, found in plot Alsószölnök 1 (III), 2 (II, III), Apátistvánfalva (I, III), Csörötnek 1 (I-III), 3, 4 (I, III), 6 (I), Felsőszölnök 1 (III), 2 (I-III), 3 (III), Kétvölgy 1 (I, III), Orfalu 2 (I), Öriszentpéter 2 (III), Szakonyfalu 1, 2 (I-III), Szalafö 2 (III), 6 (I, III), 7 (II), Szentgotthárd 1 (I-III), 2 (I) and 4 (I, III), in stand type 1-6, on dead wood of broadleaved trees.

Sparassis crispa (Wulfen) Fr., Syst. Mycol. (Lundae) 1: 465, 1821, Sparassidaceae, found in plot Öriszentpéter 4 (III), Szakonyfalu 1 (I, III), Szalafö 1 (I, III) and 4 (III), in stand type 1 and 6 , on dead wood of conifers or at base of living Pinus sylvestris.

Steccherinum bourdotii Saliba \& A. David, Cryptog. Mycol. 9(2): 100, 1988, Meruliaceae, found in plot Csörötnek 2 (III), 3 (I), 6 (III) and Szentgotthárd 2 (III), in stand type 2-4, on decaying wood of Quercus petraea.

Steccherinum cremeoalbum* Hjortstam, Mycotaxon 19: 507, 1984, Meruliaceae, found in plot Csörötnek 1 (II) and 2 (I), in stand type 1 and 2, on decaying wood of Fagus sylvatica and Carpinus betulus. Specimen examined: ORS-ERDO 116-12-1 (May 30, 2010). Spores 3.6$5.4 \times 2.3-3.6 \mu \mathrm{m}$; skeletocystidia 50.0-75.0 $\times 6.0-10.0 \mu \mathrm{m}$, incrusted, length of incrusted part: $18.0-36.0 \mu \mathrm{m}$.

Steccherinum fimbriatum (Pers.) J. Erikss., Symb. Bot. Upsal. 16(1): 134, 1958, Meruliaceae, found in plot Csörötnek 5 (I-III), Felsőszölnök 1 (I), 2 (I-III), 3 (I, II), Öriszentpéter 3 (III), Szakonyfalu 2 (I, III), Szalafö 5 (III) and Szentgotthárd 2 (III), in stand type 1-4, on decaying wood of Fagus sylvatica and Quercus petraea.

Steccherinum ochraceum (Pers.) Gray, Nat. Arr. Brit. Pl. (London) 1: 651, 1821, Meruliaceae, found in plot Alsószölnök 2 (II, III), Apátistvánfalva (III), Csörötnek 1, 2 (I-III), 3 (I), 5, 6 (II, III), Felsőszölnök 1 (I, III), 2 (I, II), 3 (I, III), Kétvölgy 2 (III), Magyarlak (III), Orfalu 1, 2 (I), 2 (III), Öriszentpéter 1 (III), 2 (I-III), 3 (II, III), 4 (I, III), Szakonyfalu 2 (I-III), 
Szalafö 2 (II, III), 3 (II), 5 (I, III), 7 (I), Szentgotthárd 1 (I), 2 (I, III) and 3 (I, II), in stand type $1-6$, on dead wood of broadleaved trees.

Stereum gausapatum (Fr.) Fr., Hymenomyc. Eur. (Upsaliae): 638, 1874, Stereaceae, found in plot Alsószölnök 1 (III), Öriszentpéter 3 (III), Rábagyarmat (I, III) and Szalafö 5 (III), in stand type 3, 4 and 6, on decaying wood of Quercus petraea and Fagus sylvatica.

Stereum hirsutum (Willd.) Pers., Observ. Mycol. (Lipsiae) 2: 90, 1800, Stereaceae, found in plot Alsószölnök 1, 2 (I, III), Apátistvánfalva (I, III), Csörötnek 1-6 (I-III), Felsőszölnök 1 (IIII), 2 (I, III), 3 (I-III), Kétvölgy 1 (I, III), 2 (III), Magyarlak (I, III), Orfalu 1, 2 (I, III), Öriszentpéter 1 (I, III), 2, 3 (I-III), 4 (I, III), Rábagyarmat (I-III), Szakonyfalu 1, 2 (I-III), Szalafö 1-3 (I, III), 4 (III), 5 (I-III), 6 (III), 7 (I, III), Szentgotthárd 1 (I, III), 2 (I-III) and 3, 4 (I, III), in stand type 1-6, on dead wood of broadleaved trees.

Stereum ochraceoflavum (Schwein.) Sacc., Syll. Fung. (Abellini) 6: 576, 1888, Stereaceae, found in plot Alsószölnök 1 (II), Csörötnek 1, 2 (III), 3 (I), 4, 5 (III), 6 (I, III), Felsöszölnök 3 (III), Kétvölgy 1 (III), 2 (I), Magyarlak (III), Orfalu 2 (I, III), Öriszentpéter 1, 2 (III), 3 (I), 4 (III), Rábagyarmat (I), (III), Szakonyfalu 1 (I), 2 (III), Szalafö 1, 2 (III), 4 (III), 5 (I, III), 6 (I, II), 7 (III), Szentgotthárd 1-3 (I, III) and 4 (III), in stand type 1-4 and 6, on dead wood of broadleaved trees.

Stereum rugosum Pers., Neues Mag. Bot. 1: 110, 1794, Stereaceae, found in plot Csörötnek 5 (I), in stand type 1, on decaying wood of Quercus petraea.

Stereum sanguinolentum (Alb. \& Schwein.) Fr., Epicr. Syst. Mycol. (Upsaliae): 549, 1838, Stereaceae, found in plot Csörötnek 2 (III), Felsőszölnök 1 (I, III), 3 (I, III), Kétvölgy 2 (III), Orfalu 2 (III), Öriszentpéter 1 (III), Szakonyfalu 2 (III), Szalafö 1, 3-7 (III), Szentgotthárd 1, 3 (III) and 4 (I), in stand type 1, 2, 4 and 6, on dead wood of conifers.

Stereum subtomentosum Pouzar, Česká Mykol. 18(3): 147, 1964, Stereaceae, found in plot Csörötnek 2, 4 (III), 5 (II, III), 6 (I, III), Felsőszölnök 2 (I), Kétvölgy 2 (I, III), Magyarlak (III), Orfalu 2 (I, III), Öriszentpéter 3 (III), Rábagyarmat (I, III), Szakonyfalu 1 (I, II), Szalafö 2 (I, III), 3 (I), 5, 7 (III), Szentgotthárd 1 (III), 2 (I, III) and 3 (III), in stand type 14 , on dead wood of broadleaved trees.

Strobilomyces strobilaceus (Scop.) Berk., Hooker's J. Bot. Kew Gard. Misc. 3: 78, 1851, Boletaceae, found in plot Csörötnek 1 (I, III), in stand type 1, on leaf litter.

Strobilurus esculentus (Wulfen) Singer, Persoonia 2(3): 414, 1962, Physalacriaceae, found in plot Alsószölnök 2 (III) and Öriszentpéter 2 (III), in stand type 5 and 6, on fallen cones of Pinus sylvestris.

Strobilurus stephanocystis (Kühner \& Romagn. ex Hora) Singer, Persoonia 2(3): 409, 1962, Physalacriaceae, found in plot Felsőszölnök 2 (II), Öriszentpéter 2 (II) and Szakonyfalu 2 (II), in stand type 1, 2 and 6, on fallen cones of Pinus sylvestris.

Strobilurus tenacellus (Pers.) Singer, Persoonia 2(3): 409, 1962, Physalacriaceae, found in plot Alsószölnök 2 (II), Kétvölgy 2 (II), Öriszentpéter 2, 4 (II), Szakonyfalu 1, 2 (II) and Szentgotthárd 4 (II), in stand type 1, 2, 5 and 6, on fallen cones.

Stropharia cyanea (Bull.) Tuom., Karstenia 2: 31, 1953, Strophariaceae, found in plot Csörötnek 1 (III), in stand type 1, on leaf litter.

Suillus bovinus (L.) Roussel, F. Calvados: 34, 1796, Suillaceae, found in plot Alsószölnök 1 (III), Apátistvánfalva (III) and Szalafö 1 (III), in stand type 6, mainly on mixed (needle and leaf), sometimes on needle litter.

Suillus luteus (L.) Roussel, F. Calvados: 34, 1796, Suillaceae, found in plot Szalafö 1 (III), in stand type 6, on mixed (needle and leaf) litter.

Suillus variegatus (Sw.) Kuntze, Revis. Gen. Pl. (Leipzig) 3: 536, 1898, Suillaceae, found in plot Orfalu 1 (III) and Öriszentpéter 2 (III), in stand type 6, on mixed (needle and leaf) litter.

Tapinella atrotomentosa (Batsch) Šutara, Česká Mykol. 46(1-2): 50, 1992, Tapinellaceae, found in plot Szalafó 7 (III) and Szentgotthárd 1 (I), in stand type 4, on decaying wood of Pinus sylvestris. 
Tapinella panuoides (Fr.) E.-J. Gilbert, Les Livres du Mycologue Tom. III: Les Bolets 68, 1931, Tapinellaceae, found in plot Alsószölnök 2 (I), in stand type 5, on decaying wood of Picea abies.

Tarzetta cupularis (L.) Svrček, Česká Mykol. 35(2): 88, 1981, Pyronemataceae, found in plot Öriszentpéter 3 (III), in stand type 3, on leaf litter.

Thelephora palmata (Scop.) Fr., Syst. Mycol. (Lundae) 1: 432, 1821, Thelephoraceae, found in plot Öriszentpéter 1, 2 (III) and Szalafö 4 (III), in stand type 6, on mixed (needle and leaf) litter.

Thelephora penicillata (Pers.) Fr., Syst. Mycol. (Lundae) 1: 434, 1821, Thelephoraceae, found in plot Szalafö 2 (I), in stand type 3, on soil among mixed (needle and leaf) litter.

Thelephora terrestris Ehrh., Pl. Crypt. Linn. Exsicc., no. 178, 1787, Thelephoraceae, found in plot Alsószölnök 1 (III), in stand type 6, on mixed (needle and leaf) litter.

Torrubiella arachnophila, anamorph Gibellula pulchra* (J.R. Johnst.) Mains, anamorph (Sacc.) Cavara, Mycologia 42(2): 316, anamorph Att. Instit. Bot. Univ. Pavia, ser 2, 3: 347, 1950, anamorph 1894, Cordycipitaceae, found in plot Szentgotthárd 4 (I), in stand type 6, on dead spider. Specimen examined: ORS-ERDO 30/21 (August 5, 2009). Teleomorph was not found; synnemata cylindrical, angustate to the apice; conidia $3.2-5.4 \times 1.1-1.3 \mu \mathrm{m}$, av. 4.2 $\times 1.2 \mu \mathrm{m}, \mathrm{Qav}=3.700, \mathrm{n}=11$, fusiform to fusiform-ellipsoid.

Trametes gibbosa (Pers.) Fr., Epicr. Syst. Mycol. (Upsaliae): 492, 1838, Polyporaceae, found in plot Csörötnek 5 (I-III) and Felsöszölnök 3 (III), in stand type 1, on decaying wood of Fagus sylvatica.

Trametes hirsuta (Wulfen) Lloyd, Mycol. Writ. 7: 1319, 1924, Polyporaceae, found in plot Alsószölnök 2 (III), Csörötnek 6 (III), Felsőszölnök 1 (I, III), 2 (III), 3 (I), Kétvölgy 1, 2 (III), Öriszentpéter 1 (I), Rábagyarmat (I-III), Szakonyfalu 1 (III), 2 (I), Szalafö 4 (III) and Szentgotthárd 4 (III), in stand type 1-6, on dead wood of broadleaved trees.

Trametes ochracea (Pers.) Gilb. \& Ryvarden, N. Amer. Polyp., vol. 2 (Oslo): 752, 1987, Polyporaceae, found in plot Felsőszölnök 1 (III), in stand type 1, on decaying wood of Fagus sylvatica.

Trametes suaveolens (L.) Fr., Epicr. Syst. Mycol. (Upsaliae): 491, 1838, Polyporaceae, found in plot Öriszentpéter 3 (I), in stand type 3, on decaying wood of Quercus petraea.

Trametes versicolor (L.) Pilát, Mycol. Notes (Cincinnati) 65: 1045, 1921, Polyporaceae, found in plot Alsószölnök 1 (III), Csörötnek 1 (III), 2 (I), 5 (I), 6 (III), Felsőszölnök 1, 3 (I, III), Kétvölgy 1 (I), 2 (I, III), Orfalu 2 (III), Öriszentpéter 1 (I, III), Szakonyfalu 1 (III), Szalafö 2 (I, III), 7 (III) and Szentgotthárd 2, 3 (III), in stand type 1-4 and 6, on dead wood of broadleaved trees.

Trametopsis cervina (Schwein.) Tomšovský, Czech Mycol. 60(1): 8, 2008, Polyporaceae, found in plot Csörötnek 5 (III), in stand type 1, on decaying wood of Fagus sylvatica.

Trechispora mollusca* (Pers.) Liberta, Can. J. Bot. 51(10): 1878, 1974, Hydnodontaceae, found in plot Alsószölnök 2 (III) and Szalafö 2 (I), in stand type 3 and 5, on dead wood of broadleaved and coniferous trees. Specimen examined: ORS-ERDO 142-52-1 (September

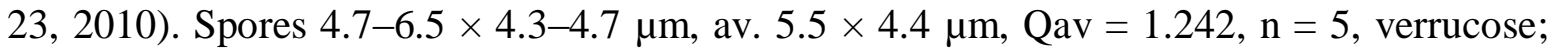
hyphal system monomitic with crystals.

Tremella encephala Pers., Syn. Meth. Fung. (Göttingen) 2: 623, 1801, Tremellaceae, found in plot Orfalu 1 (III), Öriszentpéter 2 (III), Szakonyfalu 2 (III), Szalafö 4, 7 (III) and Szentgotthárd 4 (III), in stand type 2, 4 and 6, on decaying wood of Pinus sylvestris; on sporocarp of Stereum sanguinolentum.

Tremella foliacea Pers., Observ. Mycol. (Lipsiae) 2: 98, 1800, Tremellaceae, found in plot Orfalu 1 (III), Öriszentpéter 3 (III), Rábagyarmat (I, III) and Szalafö 5 (III), in stand type 3, 4 and 6, on decaying wood of Quercus petraea.

Tremella globispora* D.A. Reid, Trans. Br. Mycol. Soc. 55(3): 414, 1970, Tremellaceae, found in plot Szentgotthárd 4 (I), in stand type 6, on decaying wood of Fagus sylvatica; on old 
stomata of Diaporthe spp. Specimen examined: ORS-ERDO 30/6 (August 5, 2009). Spores $6.5 \times 6.5 \mu \mathrm{m}$, av. $6.5 \times 6.5 \mu \mathrm{m}, \mathrm{Qav}=1.000, \mathrm{n}=5$, globose.

Tremella mesenterica Retz., K. Svenska Vetensk-Akad. Handl. 30: 249, 1769, Tremellaceae, found in plot Csörötnek 1 (I), Felsőszölnök 3 (III), Öriszentpéter 3 (III) and Szalafö 3 (III), in stand type 1, 3 and 4, on dead wood of broadleaved trees.

Trichaptum abietinum (Dicks.) Ryvarden, Norw. Jl. Bot. 19(3-4): 237, 1972, Polyporaceae, found in plot Alsószölnök 2 (I), Apátistvánfalva (I), Felsőszölnök 3 (III), Kétvölgy 2 (III), Öriszentpéter 1 (III) and Szakonyfalu 2 (II), in stand type 1, 2, 5 and 6, on dead wood of conifers.

Trichaptum biforme (Fr.) Ryvarden, Norw. Jl. Bot. 19(3-4): 237, 1972, Polyporaceae, found in plot Csörötnek 5 (I-III), 6 (III), Felsőszölnök 2 (I), Kétvölgy 2 (III) and Rábagyarmat (II), in stand type 1-4, on dead wood of broadleaved trees.

Trichaptum fuscoviolaceum (Ehrenb.) Ryvarden, Norw. Jl. Bot. 19(3-4): 237, 1972, Polyporaceae, found in plot Szalafö 2 (III) and 4 (I), in stand type 3 and 6, on decaying wood of Pinus sylvestris.

Tricholoma album (Schaeff.) P. Kumm., Führ. Pilzk. (Zwickau): 131, 1871, Tricholomataceae, found in plot Csörötnek 1, 3, 6 (III), Orfalu 2 (III), Öriszentpéter 3 (III), Szalafö 5 (III) and Szentgotthárd 2 (III), in stand type 1-4, mainly on leaf, sometimes on mixed (needle and leaf) litter.

Tricholoma batschii Gulden, Musseron flora (Oslo): 60, 1969, Tricholomataceae, found in plot Apátistvánfalva (III), in stand type 6, on mixed (needle and leaf) litter.

Tricholoma fucatum (Fr.) P. Kumm., Führ. Pilzk. (Zwickau): 130, 1871, Tricholomataceae, found in plot Szakonyfalu 1 (I) and Szalafó 1 (III), in stand type 1 and 6, on mixed (needle and leaf) litter.

Tricholoma portentosum (Fr.) Quél., Mém. Soc. Émul. Montbéliard, sér. 2, 5: 338, 1873, Tricholomataceae, found in plot Apátistvánfalva (III), Kétvölgy 1 (III), Szalafö 7 (III) and Szentgotthárd 1 (III), in stand type 1, 4 and 6, mainly on leaf, sometimes on mixed (needle and leaf) litter.

Tricholoma saponaceum (Fr.) P. Kumm., Führ. Pilzk. (Zwickau): 133, 1871, Tricholomataceae, found in plot Alsószölnök 2 (III), Csörötnek 4, 6 (III), Felsőszölnök 2 (III), Orfalu 2 (III), Öriszentpéter 1, 3 (III), Rábagyarmat (III), Szakonyfalu 1 (III), Szalafő 1, 3-7 (III) and Szentgotthárd 2, 4 (III), in stand type 1 and 3-6, mainly on leaf, sometimes on mixed (needle and leaf) litter.

Tricholoma scalpturatum (Fr.) Quél., Mém. Soc. Émul. Montbéliard, sér. 2, 5: 232, 1872, Tricholomataceae, found in plot Csörötnek 2 (III), in stand type 2, on mixed (needle and leaf) litter.

Tricholoma sciodes (Pers.) C. Martín, Add. Lichenogr. Antill.: 51, 1919, Tricholomataceae, found in plot Csörötnek 4 (III), Felsőszölnök 1-3 (III), Kétvölgy 1 (III), Szakonyfalu 1 (III) and Szalafö 3, 6 (III), in stand type 1, 3 and 4, mainly on leaf, sometimes on mixed (needle and leaf) litter.

Tricholoma stiparophyllum (N. Lund) P. Karst., Bidr. Känn. Finl. Nat. Folk 32: 42, 1879, Tricholomataceae, found in plot Kétvölgy 2 (III), in stand type 2, on mixed (needle and leaf) litter.

Tricholoma sulphureum (Bull.) P. Kumm., Führ. Pilzk. (Zwickau): 133, 1871, Tricholomataceae, found in plot Apátistvánfalva (III), Csörötnek 3, 5, 6 (III), Felsőszölnök 1-3 (III), Kétvölgy 1, 2 (III), Orfalu 2 (III), Öriszentpéter 3 (III), Szakonyfalu 2 (III), Szalafő 1-7 (III) and Szentgotthárd 2, 4 (III), in stand type 1-4 and 6, mainly on leaf, sometimes on mixed (needle and leaf) litter.

Tricholoma ustale (Fr.) P. Kumm., Führ. Pilzk. (Zwickau): 130, 1871, Tricholomataceae, found in plot Csörötnek 3-5 (III), Felsőszölnök 1-3 (III), Kétvölgy 1, 2 (III), Orfalu 1 (III), Rábagyarmat (III), Szakonyfalu 1 (III), Szalafő 2-6 (III) and Szentgotthárd 4 (III), in stand type 1-4 and 6, mainly on leaf, sometimes on mixed (needle and leaf) litter. 
Tricholomopsis rutilans (Schaeff.) Singer, Schweiz. Z. Pilzk. 17: 56, 1939, Tricholomataceae, found in plot Kétvölgy 2 (III) and Szalafö 3, 4 (III), in stand type 2, 4 and 6, on decaying wood of Pinus sylvestris.

Tubaria conspersa (Pers.) Fayod, Annls Sci. Nat. Bot., sér. 7, 9: 355, 1889, Tubariaceae, found in plot Csörötnek 3, 5 (III) and Szalafö 5 (III), in stand type 1, 2 and 4, on leaf litter.

Tubaria furfuracea (Pers.) Gillet, Hyménomycètes (Alençon): 537, 1876, Tubariaceae, found in plot Csörötnek 1 (III), Szakonyfalu 1 (III) and 2 (II), in stand type 1 and 2, mainly on leaf, sometimes on mixed (needle and leaf) litter or on decaying wood of Fagus sylvatica.

Tubaria minutalis Romagn., Revue Mycol. (Paris) 2(5): 192, 1937, Tubariaceae, found in plot Csörötnek 1 (III), Öriszentpéter 4 (III), Szakonyfalu 2 (III), Szalafö 1 (III) and Szentgotthárd 4 (III), in stand type 1, 2 and 6, on mixed (needle and leaf) litter.

Tylopilus felleus (Bull.) P. Karst., Revue Mycol. (Toulouse) 3(9): 16, 1881, Boletaceae, found in plot Öriszentpéter 2 (I), Szalafö 1 (III), 3 (I) and Szentgotthárd 4 (I), in stand type 4 and 6, mainly on mixed (needle and leaf), sometimes on needle litter.

Tyromyces chioneus (Fr.) P. Karst., Revue Mycol. (Toulouse) 3(9): 17, 1881, Polyporaceae, found in plot Szalafó 2 (III), in stand type 3, on decaying wood of Quercus petraea.

Volvariella caesiotincta P.D. Orton, Bull. Mens. Soc. Linn. Lyon, 43: 319, 1974, Pluteaceae, found in plot Kétvölgy 2 (I), in stand type 2, on very decayed wood.

Xerocomus badius (Fr.) E.-J. Gilbert, Les Livres du Mycologue Tom. III: Les Bolets 92, 1931, Boletaceae, found in plot Alsószölnök 1, 2 (III), Apátistvánfalva (III), Orfalu 1 (III), Öriszentpéter 4 (III), Szalafö 1 (III) and Szentgotthárd 4 (III), in stand type 5 and 6, on mixed (needle and leaf) litter.

Xerocomus chrysonema* A.E. Hills \& A.F.S. Taylor, Mycol. Res. 110(3): 283, 2006, Boletaceae, found in plot Öriszentpéter 3 (I), in stand type 3, on leaf litter. Specimen examined: ORSERDO 1/8 (August 1, 2009). Spores 10.6-13.8 × 5.0-5.9 $\mu \mathrm{m}$, av. $12.2 \times 5.5 \mu \mathrm{m}$, Qav $=$ $2.160, \mathrm{n}=10$, subfusiform.

Xerocomus cisalpinus Simonini, H. Ladurner \& Peintner, Mycol. Res. 107(6): 664, 2003, Boletaceae, found in plot Csörötnek 1 (III) and 4 (II), in stand type 1 and 3, on leaf litter.

Xerocomus ferrugineus (Schaeff.) Alessio, Boletus Dill. ex L. (Saronno): 282, 1985, Boletaceae, found in plot Öriszentpéter 3 (III) and Szalafö 1 (III), in stand type 3 and 6, on mixed (needle and leaf) litter.

Xerocomus parasiticus (Bull.) Quél., Fl. Mycol. France (Paris): 418, 1888, Boletaceae, found in plot Alsószölnök 1 (I, III), in stand type 6, on mixed (needle and leaf) litter, together with Scleroderma citrinum.

Xerocomus porosporus Imler, Bull. Trimest. Soc. Mycol. Fr. 74: 97, 1958, Boletaceae, found in plot Öriszentpéter 3 (I) and 4 (III), in stand type 3 and 6, mainly on mixed (needle and leaf), sometimes on leaf litter.

Xerocomus pruinatus (Fr. \& Hök) Quél., Fl. Mycol. France (Paris): 420, 1888, Boletaceae, found in plot Alsószölnök 1, 2 (III), Apátistvánfalva (III), Csörötnek 2-6 (III), Felsőszölnök 1-3 (III), Kétvölgy 1, 2 (III), Magyarlak (III), Orfalu 1 (III), Öriszentpéter 3, 4 (III), Rábagyarmat (III), Szakonyfalu 1, 2 (III), Szalafö 3, 4 (III) and Szentgotthárd 1-4 (III), in stand type 1-6, mainly on leaf, sometimes on mixed (needle and leaf) litter.

Xerocomus ripariellus Redeuilh, Docums. Mycol. 26(104): 30, 1997, Boletaceae, found in plot Csörötnek 6 (I), in stand type 4, on needle litter.

Xerocomus subtomentosus (L.) Quél., Fl. Mycol. France (Paris): 418, 1888, Boletaceae, found in plot Csörötnek 6 (I), Felsőszölnök 2 (I), Magyarlak (I), Öriszentpéter 3 (I), Rábagyarmat (I) and Szalafö 5 (I), in stand type 1, 3 and 4, on leaf litter.

Xerula pudens (Pers.) Singer, Lilloa 22: 289, 1951, Physalacriaceae, found in plot Magyarlak (III), in stand type 3, on buried decaying wood of Quercus petraea.

Xylaria carpophila (Pers.) Fr., Summa veg. Scand. (Stockholm) 2: 382, 1849, Xylariaceae, found in plot Alsószölnök 1 (III), Apátistvánfalva (I), Csörötnek 1, 3, 5 (III), Felsőszölnök 1 (I), 2, 
3 (I, III), Kétvölgy 1 (I, III), 2 (I), Szakonyfalu 1, 2 (I) and Szentgotthárd 1-3 (I), in stand type 1-4 and 6, on decaying cupule litter of Fagus sylvatica.

Xylaria hypoxylon (L.) Grev., Fl. Edin.: 355, 1824, Xylariaceae, found in plot Alsószölnök 1 (III), 2 (I, III), Apátistvánfalva (III), Csörötnek 1 (III), 2, 3 (I, III), 4, 5 (III), Felsőszölnök 1 (I, III), 2 (III), 3 (I, III), Kétvölgy 2 (III), Orfalu 1 (I), Öriszentpéter 1, 3 (III), Rábagyarmat (III), Szakonyfalu 1, 2 (III), Szalafő 4-6 (III), Szentgotthárd 1 (I), 2 (I, III), 3 (I) and 4 (III), in stand type 1-6, on dead wood of broadleaved trees.

Xylaria longipes Nitschke, Pyrenomycetes Germanici 1: 14, 1867, Xylariaceae, found in plot Alsószölnök 2 (I), Csörötnek 1 (I, III), 3 (III), Öriszentpéter 1 (I) and Szakonyfalu 1, 2 (III), in stand type 1,2, 5 and 6, on decaying wood of Fagus sylvatica and Carpinus betulus.

Xylaria polymorpha (Pers.) Grev., Fl. Edin.: 355, 1824, Xylariaceae, found in plot Csörötnek 1 (IIII), 5 (III), Felsőszölnök 2 (II), 3 (I), Rábagyarmat (II), Szakonyfalu 1 (II) and Szentgotthárd 3, 4 (I), in stand type 1-3 and 6, on dead wood of broadleaved trees.

\section{Acknowledgements}

This study was supported by the Hungarian Scientific Research Fund (OTKA, K79158) and the Directorate of Örség National Park. P Ódor is a grantee of János Bolyai Scholarship.

Field surveys and identifications were headed by I Siller. The identification of ectomycorrhizal and some terricolous saprotrophic species were completed by B Dima and K Takács. Most of the terricolous saprotrophic and all lignicolous macrofungi taxa were identified by I Siller and G Kutszegi. The members of the field crew were I Siller, B Dima, G Kutszegi, Zs Merényi, K Takács, T Varga and G Turcsányi. G Kutszegi had the main role in writing. Örs-erdő Project was headed by P Ódor.

\section{References}

Bas C, Kuyper ThW, Noordeloos ME, Vellinga EC (eds). 1990, 1995, 1999 - Flora Agaricina Neerlandica - Critical monographs on families of agarics and boleti occuring in the Netherlands. Vol. 2-4. A.A.Balkema, Rotterdam.

Basso MT. 1999 - Lactarius Pers. Fungi Europaei, Vol. 7. Massimo Candusso, Alassio.

Bello J, Lence C, Acedo C. 2009 - Anthina flammea Fr. (Deuteromycota, Fungi) en el Bierzo (León, N.O. España). Acta Botanica Malacitana 34, 254-255.

Bernicchia A. 2005 - Polyporaceae s.l. Fungi Europaei, Vol. 10. Edizioni Candusso, Alassio.

Bernicchia A, Gorjón S. 2010 - Corticiaceae s.l. Fungi Europaei, Vol. 12. Edizioni Candusso, Alassio.

Bidaud A, Carteret X, Eyssartier G, Moënne-Loccoz P, Reumaux P. 2002-2004 - Atlas des Cortinaires. Pars 12-14. S. A. R. L. Ed. Fédérat. Mycol. Dauphiné-Savoie, Lomazzo, Lyon.

Bidaud A, Moënne-Loccoz P, Reumaux P, Carteret X. 2001, 2008, 2010 Atlas des Cortinaires. Pars 11, 17, 19. S. A. R. L. Ed. Fédérat. Mycol. Dauphiné-Savoie, Lomazzo, Lyon.

Bidaud A, Moënne-Loccoz P, Reumaux P, Carteret X, Eyssartier G, Henry R. 2000 - Atlas des Cortinaires. Pars 10. S. A. R. L. Ed. Fédérat. Mycol. Dauphiné-Savoie, Lyon.

Brandrud TE, Lindström H, Marklund H, Melot J, Muskos S. 1990, 1992, 1994, 1998 - Cortinarius Flora Photographica, Parts 1-4. Cortinarius HB, Klövervägen, Matfors, Sweden.

Bratek Z, Balázs T, Zöld-Balogh Á. 2003 - Adatok a Nyugat-Dunántúl aszkomicétáinak ismeretéhez [Reporting Discomycetes from West-trans-Danubia]. Háromoldalú Botanikai és Mikológiai konferencia, Szentgotthárd, 146-161.

Breitenbach J, Kränzlin F. 1984, 1986, 1991, 1995, 2000 - Pilze der Schweiz. Band 1-5. Mykologia, Luzern.

Carbone M, van Vooren N. 2010 - Il genere Otidea - II. Otidea fuckelii, una nuova specie pubblicata per chiarire le differenti interpretazioni di O. leporina. Rivista di Micologia 52(4), $313-330$.

Christan J. 2008 - Die Gattung Ramaria in Deutschland. IHW-Verlag, Eching. 
Consiglio G, Antonini D, Antonini M. 2003-2007 - Il Genere Cortinarius in Italia. Parte 1-5. A.M.B. Fondazione, Centro Studi Micologici.

Consiglio G, Setti L. 2008 - Il Genere Crepidotus in Europa. A.M.B. Fondazione, Centro Studi Micologici.

Courtecuisse R, Duhem B. 1994 - Guide des champignons de France et d'Europe. Delachaux et Niestlé, Paris.

Dövényi Z. 2010 - Magyarország kistájainak katasztere [Cadastre of Hungarian regions]. MTA Földrajztudományi Intézet, Budapest.

Galli R. 1996 - Le Russule. Edinatura, Milano.

Galli R. 2001 - Le Amanite. Edinatura, Milano.

Galli R. 2006 - I Lattari. dalla Natura, Milano.

Ghyselinck D. 2013 - Les Cordyceps de Belgique. Available online at: http://home.scarlet.be/daniel.ghyselinck3/Cordyceps.htm (assessed 15 June, 2013).

Halász G. (ed) 2006 - Magyarország erdészeti tájai [Forest regions of Hungary]. Állami Erdészeti Szolgálat, Budapest.

Hansen L, Knudsen H. (eds) 1997, 2000 - Nordic Macromycetes. Vol. 1, 3. Nordsvamp, Copenhagen.

Hausknecht A. 2009 - A monograph of the genera Conocybe Fayod, Pholiotina Fayod in Europe. Fungi Europaei, Vol. 11. Edizioni Candusso, Alassio.

Heilmann-Clausen J, Verbeken A, Vesterholt J. 2000 - The genus Lactarius. Fungi of Northern Europe, Vol. 2. The Danish Mycological Society.

Huhtinen S, Ruotsalainen J. 2006 - Variability of Hydnum rufescens in Finland: three taxa hidden under one name - and appearance? Karstenia 46, 17-24.

Juhász P, Bidló A, Heil B, Kovács G, Ódor P. 2011 - Örségi erdőtalajok széntartalmi vizsgálata [Investigation of soil carbon content in Örség (West Hungary)]. Talajvédelem, Talajvédelmi Alapítvány lektorált különszáma, Szeged.

Jülich W. 1984 - Basidiomyceten 1. Teil, Die Nichtblätterpilze, Gallertpilze und Bauchpilze. Gustav Fischer Verlag, Stuttgart.

Kirk PM, Ansell AE. 1992 - Authors of fungal names: a list of authors of scientific names of fungi, with recommended standard forms of their names, including abbreviations. Index of Fungi

Supplement. Wallingford, UK: CAB International. www.indexfungorum.org/Names/AuthorsOfFungalNames.asp (assessed 25 April, 2013).

Knudsen H, Vesterholt J. (eds) 2012 - Funga Nordica, Agaricoid, boletoid, clavarioid, cyphelloid and gastroid genera. Nordsvamp, Copenhagen.

Krieglsteiner GJ. 2000a, 2000b, 2001, 2003 - Die Großpilze Baden-Württembergs, Band 1-4. Verlag Eugen Ulmer GmbH \& Co., Stuttgart.

Krieglsteiner GJ, Gminder A. 2010 - Die Großpilze Baden-Württembergs. Band 5. Eugen Ulmer KG, Stuttgart.

Kobayasi Y. 1941 - The genus Cordyceps and its allies. Science reports of the Tokyo Bunrika Daigaku, Section B 5 (84), 53-260.

Kobayasi Y, Shimizu D. 1982 - Monograph of the genus Torrubiella. Bulletin of the National Science Museum, Tokyo 8, 43-78.

Kuyper ThW. 1986 - A revision of the genus Inocybe in Europe I. Subgenus Inosperma and the smooth-spored species of subgenus Inocybe. Persoonia Supplement 3, 1-247.

Ladurner H, Simonini G. 2003 - Xerocomus s.l. Fungi Europaei, Vol. 8. Edizioni Candusso, Alassio.

Larsson E, Ryberg M, Moreau P-A, Delcuse Mathiesen Å, Jacobsson S. 2009 - Taxonomy and evolutionary relationships within species of section Rimosae (Inocybe) based on ITS, LSU and $\mathrm{mtSSU}$ sequence data. Persoonia 23, 86-98.

Lindahl BD, Finlay RD, Cairney JWG. 2005 - Enzymatic activities of mycelia in mycorrhizal fungal communities. In: The Fungal Community: its organization and role in the ecosystem. 
$3^{\text {rd }}$ Ed (Dighton J, White JF Jr., Oudemans P, eds). Taylor \& Francis Group, Boca Raton. 331-348.

Lukács Z, Nyilas I, Bathó A, Gábor E, Polgári J. 2001 - Gombakutatások az Örségben a Zala megyei Csödén, ill. a szomszédos Vas megye néhány településének környékén I. [Mycological work in environs of Csöde and in another places of Örség (West Hungary)]. Mikológiai Közlemények, Clusiana 40(1-2), 77-88.

Miettinen O, Niemelä T, Spirin W. 2006 - Northern Antrodiella species: the identity of A. semisupina, and type studies of related taxa. Mycotaxon 96, 211-239.

Moser M, Jülich W. 1985 - Farbatlas der Basidiomyceten. Gustav Fischer Verlag, Stuttgart.

Niskanen T. 2008 - Cortinarius subgenus Telamonia p.p. in North Europe. Academic (PhD) dissertation, University of Helsinki, Helsinki.

Olariaga I, Grebenc T, Salcedo I, Martín MP. 2012 - Two new species of Hydnum with ovoid basidiospores: H. ovoideisporum and H. vesterholtii. Mycologia 104(6), 1443-1455.

Örs-erdő Project 2013 - The effect of stand structure on the composition and diversity of different organism groups in Örség (Western Hungary).

http://ramet.elte.hu/ ramet/project/ors_erdo/index_en.htm

Rimóczi I, Siller I, Vasas G, Albert L, Vetter J, Bratek Z. 1999 - Magyarország nagygombáinak javasolt vörös listája [Macrofungi taxa recommended to be red-listed in Hungary]. Mikológiai Közlemények, Clusiana 38(1-3), 107-132.

Roberts P. 2009 - Exidia nigricans: a new and legitimate name for Exidia plana. Mycotaxon 109, 219-220.

Robich G. 2003 - Mycena D’Europa. A.M.B. Fondazione, Centro Studi Micologici.

Ryvarden L, Gilbertson RL. 1993, 1994 - European Polypores. Part 1-2. Fungiflora, Oslo.

Saar G. 2010 - Die Arten aus dem Cortinarius largus-/variecolor-Komplex. Section Phlegmacioides (= Variecolores) Journal J.E.C. 12, 42-56.

Sarnari M. 1998, 2005 - Monografia illustrata del Genere Russula in Europa. Tomo 1-2. A.M.B. Fondazione, Centro Studi Micologici.

Siller I. 2003 - Neuere Pilzfunde von Aphyllophorales im Nationalpark Örség. Trilaterale Botanische und Mykologische Tagung, Sonderausgabe, Szentgotthárd, 173-184.

Sopp L, Kolozs L. 2000 - Fatömegszámítási táblázatok [Volume tables for trees]. Állami Erdészeti Szolgálat, Budapest.

Tímár G, Ódor P, Bodonczi L. 2002 - The characteristics of forest vegetation of the Örség Landscape Protected Area. Kanitzia 10, 109-136.

Tomšovský M. 2008 - Molecular phylogeny and taxonomic position of Trametes cervina and description of a new genus Trametopsis. Czech Mycology 60(1), 1-11.

Vasas G, Locsmándi Cs. 1995 - The macroscopic fungi (Basidiomycetes) of Örség, Western Hungary. Savaria, a Vas megyei múzeumok értesítője 22(2), 265-294.

Vesterholt J. 2005 - The genus Hebeloma. Fungi of Northern Europe, Vol. 3. The Danish Mycological Society.

Wagner T, Fischer M. 2002 - Classification and phylogenetic relationships of Hymenochaete and allied genera of the Hymenochaetales, inferred from rDNA sequence data and nuclear behaviour of vegetative mycelium. Mycological Progress 1(1), 93-104.

Zagyva T. 2000 - Szubalpin gyepek mikológiai felmérése az Örségi Tájvédelmi Körzetben [Mycoflora of the subalpine meadow at the Örség Landscape Conservation Area]. Mikológiai Közlemények, Clusiana 39(1-2), 31-92. 